\title{
A Role of Endogenous Progesterone in Stroke Cerebroprotection Revealed by the Neural-Specific Deletion of Its Intracellular Receptors
}

\author{
Xiaoyan Zhu, ${ }^{1}$ Magalie Fréchou, ${ }^{1}$ Philippe Liere, ${ }^{1}$ Shaodong Zhang, ${ }^{1,2}$ Antoine Pianos, ${ }^{1} \odot$ Neïké Fernandez, \\ Christian Denier, ${ }^{1,3}$ Claudia Mattern, ${ }^{4}$ Michael Schumacher, ${ }^{1}$ and $₫$ Rachida Guennoun ${ }^{1}$ \\ ${ }^{1}$ U1195 Inserm and University Paris-Sud and University Paris-Saclay, 94276 Kremlin-Bicêtre, France, ${ }^{2 B}$ Beijing Neurosurgical Institute, Beijing 100050, \\ China, ${ }^{3}$ Department of Neurology and Stroke Center, Bicêtre Hospital, 94276 Kremlin-Bicêtre, France, and ${ }^{4}$ MetP Pharma AG, 6376 Emmetten, Switzerland
}

Treatment with progesterone protects the male and female brain against damage after middle cerebral artery occlusion (MCA0). However, in both sexes, the brain contains significant amounts of endogenous progesterone. It is not known whether endogenously produced progesterone enhances the resistance of the brain to ischemic insult. Here, we used steroid profiling by gas chromatography-tandem mass spectrometry (GC-MS/MS) for exploring adaptive and sex-specific changes in brain levels of progesterone and its metabolites after MCA0. We show that, in the male mouse brain, progesterone is mainly metabolized via $5 \alpha$-reduction leading to $5 \alpha$-dihydroprogesterone ( $5 \alpha$-DHP), also a progesterone receptor (PR) agonist ligand in neural cells, then to $3 \alpha, 5 \alpha$-tetrahydroprogesterone ( $3 \alpha, 5 \alpha$-THP). In the female mouse brain, levels of $5 \alpha$-DHP and $3 \alpha, 5 \alpha$-THP are lower and levels of $20 \alpha$-DHP are higher than in males. After MCA0, levels of progesterone and $5 \alpha$-DHP are upregulated rapidly to pregnancy-like levels in the male but not in the female brain. To assess whether endogenous progesterone and $5 \alpha$-DHP contribute to the resistance of neural cells to ischemic damage, we inactivated PR selectively in the CNS. Deletion of PR in the brain reduced its resistance to MCAO, resulting in increased infarct volumes and neurological deficits in both sexes. Importantly, endogenous PR ligands continue to protect the brain of aging mice. These results uncover the unexpected importance of endogenous progesterone and its metabolites in cerebroprotection. They also reveal that the female reproductive hormone progesterone is an endogenous cerebroprotective neurosteroid in both sexes.

Key words: aging; endogenous; neuroprotection; progesterone receptors; sex differences; steroids

\section{Significance Statement}

The brain responds to injury with protective signaling and has a remarkable capacity to protect itself. We show here that, in response to ischemic stroke, levels of progesterone and its neuroactive metabolite $5 \alpha$-dihydroprogesterone are upregulated rapidly in the male mouse brain but not in the female brain. An important role of endogenous progesterone in cerebroprotection was demonstrated by the conditional inactivation of its receptor in neural cells. These results show the importance of endogenous progesterone, its metabolites, and neural progesterone receptors in acute cerebroprotection after stroke. This new concept could be exploited therapeutically by taking into account the progesterone status of patients and by supplementing and reinforcing endogenous progesterone signaling for attaining its full cerebroprotective potential.

\section{Introduction}

The very rapid loss of brain tissue after the onset of ischemic stroke represents a major therapeutic challenge (Saver, 2006). To date, the only acute treatments for ischemic stroke are thrombolysis with tissue plasminogen activator and removal of the thrombus with a retriever stent (Vivien et al., 2011; Campbell et al., 2015). These reperfusion therapies would benefit from the com-

X. Zhu's present address: College of Veterinary Medicine, Northwest A\&F University, Yangling 712100, Shaanxi, China.

Correspondence should be addressed to either Dr. Rachida Guennoun or Dr. Michael Schumacher, U1195 Inserm and University Paris-Sud and University Paris-Saclay, 80 rue du Général Leclerc, 94276 Kremlin-Bicêtre, France, E-mail: rachida.guennoun@inserm.fr or michael.schumacher@inserm.fr.

DOI:10.1523/JNEUROSCI.3874-16.2017

Copyright $\odot 2017$ the authors $\quad 0270-6474 / 17 / 3710998-23 \$ 15.00 / 0$ 


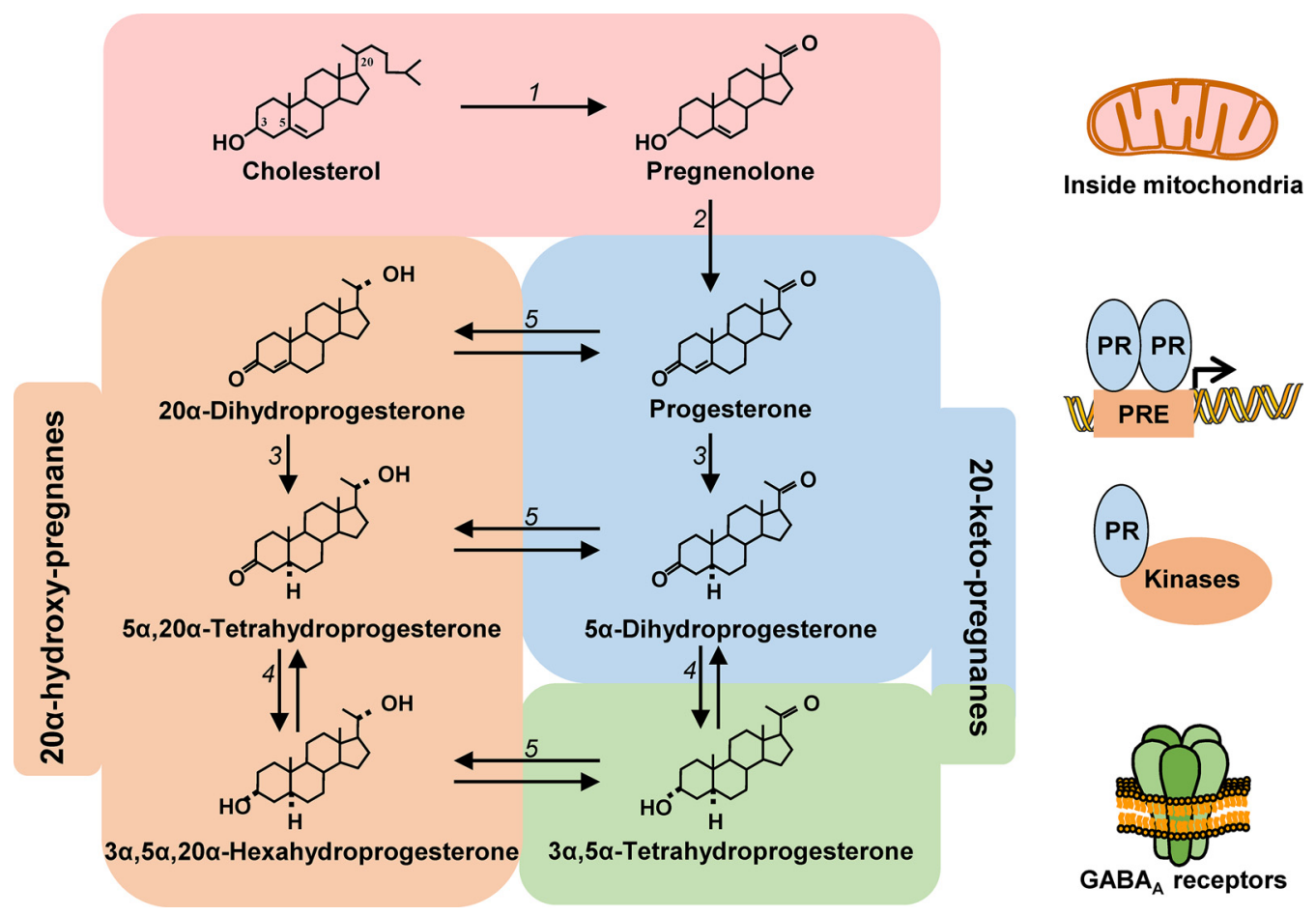

Figure 1. Schematic presentation of the single biosynthetic pathway starting with cholesterol and leading to progesterone, its metabolites, and their main signaling mechanisms. Enzymes are shown as numbers in italics next to the arrows indicating metabolic steps. Cholesterol is converted to pregnenolone inside the steroidogenic mitochondria by cytochrome P450scc (1). Carbons are numbered as shown. Pregnenolone is then converted to progesterone by the $3 \beta$-hydroxysteroid dehydrogenases (2) and progesterone to $5 \alpha$-dihydroprogesterone ( $5 \alpha$-DHP) by the $5 \alpha$-reductases (3). Both progesterone and $5 \alpha$-DHP bind to intracellular PRs, which regulate gene transcription inside the nucleus, but also interact with membrane-associated kinases in extranuclear compartments. The conversion of $5 \alpha$-DHP to $3 \alpha, 5 \alpha$-THP (allopregnanolone) by the $3 \alpha$-hydroxysteroid dehydrogenase (4) is a reversible reaction. In contrast to progesterone and $5 \alpha$-DHP, $3 \alpha, 5 \alpha$-THP does not bind to PR, but is a positive modulator of $G A B A_{A}$ receptors. The interconversion of 20-keto-pregnanes to $20 \alpha$-hydroxy-pregnanes, considered as biologically inactive, is also reversible and catalyzed by a $20 \alpha$-hydroxysteroid dehydrogenase (5).

bined use of a cerebroprotective agent, which may prolong the survival of neural cells and extend the very short $4.5 \mathrm{~h}$ time window to reperfusion. In addition, a cerebroprotective agent may limit tissue damage resulting from reperfusion (Donnan et al., 2011; Fisher, 2011).

Treatment with exogenous progesterone has been demonstrated to protect the male and female rodent brain against ischemic damage after middle cerebral artery occlusion (MCAO) (Sayeed and Stein, 2009; Gibson et al., 2011). Notably, progesterone treatment shows long-lasting cerebroprotective efficacy with a $6 \mathrm{~h}$ window of opportunity (Gibson et al., 2011; Wali et al., 2014). However, it is unknown whether endogenous progesterone plays a role in cerebroprotective mechanisms. In adult males and females, neural cells are indeed exposed to significant levels of progesterone either derived from the ovaries in females or from the adrenal glands in both sexes (Schumacher et al., 2014). Moreover, progesterone is a "neurosteroid" synthesized de novo within the brain (Baulieu, 1997).

The aim of the present study was to assess whether endogenous progesterone and its metabolites are involved in acute selfprotection of the male and female mouse brain against ischemic damage. This is an important problem because there is an ongoing interest in taking advantage of endogenous cerebroprotective mechanisms for therapeutic purposes (Iadecola and Anrather, 2011; Mergenthaler and Dirnagl, 2011). However, assessment of the cerebroprotective actions of progesterone requires taking into account its extensive metabolism in the brain (Schumacher et al., 2014). Therefore, progesterone is readily converted to $5 \alpha$-dihydroprogesterone ( $5 \alpha$-DHP) by neural cells (Celotti et al., 1992). In these cells, both progesterone and $5 \alpha$-DHP activate gene transcription via progesterone receptors (PRs) (Rupprecht et al., 1993) (see Fig. 1). The PRs are ligand-activated transcription factors, but they also interact with membrane-associated kinases outside of the nucleus (Lange et al., 2007; Grimm et al., 2016). We have demonstrated recently that PRs play a key role in the cerebroprotective actions of progesterone after MCAO (Liu et al., 2012). The progesterone metabolite $5 \alpha$-DHP is further converted to $3 \alpha, 5 \alpha$-tetrahydroprogesterone ( $3 \alpha, 5 \alpha$-THP), also well known as allopregnanolone, which does not bind to PR but functions as a positive modulator of $\mathrm{GABA}_{\mathrm{A}}$ receptors, resulting in the inhibition of neuronal activity (Fig. 1) (Hosie et al., 2006; Lambert et al., 2009). The conversion to $20 \alpha$-dihydroprogesterone (20 $\alpha$-DHP) is an additional metabolic pathway of progesterone. Because $20 \alpha$-DHP has low affinity for PRs and no progestogenic activity, the $20 \alpha$ reduction is generally considered as an inactivation pathway of progesterone (Fig. 1). However, progesterone and $20 \alpha$-DHP are interconvertible and $20 \alpha$-DHP may thus serve as a reservoir for progesterone and its biologically active metabolites (Hillisch et al., 2003; Williams et al., 2012).

We used sensitive and specific gas chromatography-tandem mass spectrometry (GC-MS/MS) for establishing steroid profiles in the brain and plasma of intact and ischemied male and female C57BL/ 6 mice. We found that levels of $5 \alpha$-DHP and $3 \alpha, 5 \alpha$-THP were higher whereas levels of $20 \alpha$-DHP were lower in the male brain than in the female brain. During the first $6 \mathrm{~h}$ after MCAO, there was a rapid and major increase in the levels of progesterone and $5 \alpha$-DHP in the male brain, but, surprisingly, not in the female brain. To determine whether endogenous PR-active progesterone and $5 \alpha$-DHP are involved in the acute resistance of the brain to ischemic damage, we inactivated PRs selectively in neural 
cells. Lack of neural PRs increased the vulnerability of the brains of both male and female young and aging mice.

\section{Materials and Methods}

\section{Ethical statement}

Procedures concerning animal care and use were performed in accordance with national guidelines (authorization 94-345 to R.G., animal facility approval 94-043-13), French ethical laws (Act 87-848 and Act 2013-11), and European Communities Council Directive (86/609/ EEC) and have been approved by the ethical committee of French Ministry of Higher Education and Research C2EA-26 (project 2014_029). All experiments were performed following the ARRIVE guidelines (www.nc3rs.org.uk).

Generation of mice with conditional invalidation of $P R$ gene in the nervous system

Generation of $P R^{+/ \text {loxP }}$ mice. $\mathrm{PR}^{+/ \text {loxP }}$ mice were generated by the Mouse Clinical Institute (MCI, Illkirch, France). Exon 2 of the PR genomic locus was targeted to generate a conditional allele. The modified PR allele $\mathrm{PR}^{\operatorname{lox} \mathrm{P}}$ in which exon 2 was flanked by loxP sites was generated by homologous recombination in embryonic stem cells. Exon 2 encodes the first zinc finger of the DNA-binding domain of the receptor (Hill et al., 2012). The $P R^{\text {loxP/loxP }}$ mouse was crossed with a mouse expressing the Cre recombinase driven by the promoter and the CNS-specific enhancer of rat Nestin (Nes). In this mouse, the Cre recombinase is selectively expressed in CNS neurons, astrocytes, and oligodendrocytes, but not in microglial cells (Tronche et al., 1999). We used this Nestin-Cre mouse strain because of its well characterized efficiency of Cre-mediated recombination, resulting in the almost complete deletion of floxed steroid receptor genes in the brain (Tronche et al., 1999; Raskin et al., 2009).

Breeding colony establishment. Two breeding colonies, $\mathrm{PR}{ }^{\text {loxP/loxP }}$ mice and PR Nescre mice (C57BL/6 background), were established in our animal facility (U1195 Inserm, Kremlin-Bicêtre). Male and female heterozygotes $P R^{+/ l o x P}$ mice were crossed. Pups were screened and $P R^{\text {loxP /loxP }}$ mice were selected. Male and female PR ${ }^{\operatorname{loxP} / \text { loxP }}$ mice were crossed to establish a $\mathrm{PR}^{\text {loxP/loxP }}$ colony. We also generated a transgenic colony of $\mathrm{PR}^{\text {NesCre }}$ mice that selectively lack PRs in the neural cells using the Crelox strategy. Male mice $\mathrm{PR}^{+/+} \mathrm{Tg}$ (NesCre) were mated with female $\mathrm{PR}^{\text {loxP } /+}$ mice to obtain $\mathrm{PR}^{+/ \text {loxP }} \mathrm{Tg}$ (NesCre) mice. Male $\mathrm{PR}^{+/ \text {loxP }} \mathrm{Tg}$ (NesCre mice) were crossed with female $\mathrm{PR}^{\text {loxP/loxP }}$. Male $\mathrm{PR}^{\text {loxP/loxP }} \mathrm{Tg}$ (NesCre) were selected and crossed with female $\mathrm{PR}^{\text {loxP/loxP }}$ to establish the breeding colony of $\mathrm{PR} \mathrm{P}^{\text {loxP/loxP NesCre }}$, which will be referred to as $\mathrm{PR}^{\mathrm{Nes} C r e}$ mice.

Mice were weaned at $21 \mathrm{~d}$ of age and each mouse was identified and genotyped by PCR using genomic DNA from tail to assess the presence of loxP sites and Cre recombinase using specific primers. Screening for LoxP sites was as follows: F1: 5'-AACATGGAAGGATGCACCTGTT CCC-3'; R1: 5'-GCCTTGAACTCATGAATTCCCAGCTTC-3'; F2: 5'ССTTCССTCTCATTGTCATG GAGAC-3'; R2: 5'-AGAGAATCTCTC GCCAGTGTCATGG-3'. Screening for Nes Cre transgene was as follows: F3: 5'-GCGGTCTGGCAGTAAAAACTATC-3'; R3: 5'-GTGAAACAG CATTGCT GTCACTT-3'. The internal positive control for PCR amplification was as follows: F4: 5'-CTAGGCCACAGAATT GAAAGA TCT-3'; R4: 5'-GTAGGTGGAAATTCTAGCATCATCC-3'). Mice were group housed in a temperature-controlled room $\left(22^{\circ} \mathrm{C}\right)$ and photoperiod (12 h light/12 h dark; lights on from 8:00 A.M. to 8:00 P.M.), with food and water available ad libitum.

\section{Transient MCAO model}

Transient cerebral ischemia was performed under ketamine $(50 \mathrm{mg} / \mathrm{kg})$ and xylazine hydrochloride $(6 \mathrm{mg} / \mathrm{kg})$ anesthesia. Body temperature of the mice was monitored by a rectal probe and maintained constant at $36-38^{\circ} \mathrm{C}$ during surgery with the aid of a homeothermic blanket control unit (Harvard Apparatus). Cerebral blood flow was monitored by laser Doppler flowmetry (Moor Instruments) $5 \mathrm{~min}$ before and $5 \mathrm{~min}$ after MCAO. A $>70 \%$ drop of blood flow was considered a successful MCAO and mice that did not reach the required decrease were excluded from the study.

MCAO was performed for $30 \mathrm{~min}$ as described previously (Gibson and Murphy, 2004). Briefly, the left common carotid artery was isolated. A nylon monofilament ( $83 \mu \mathrm{m}$ diameter; Drennan) coated with thermomelting glue ( $4 \mathrm{~mm}$ long, $190 \mu \mathrm{m}$ diameter) was introduced through an arteriotomy performed in the common carotid artery and advanced into the internal carotid artery to occlude the origin of the middle cerebral artery. The filament was withdrawn $30 \mathrm{~min}$ after occlusion to allow reperfusion.

Sham-operated mice underwent the same surgical procedures except that no filament was inserted. After reperfusion, the skin was adapted with a surgical suture. Mice received $0.5 \mathrm{ml}$ of $\mathrm{NaCl} 0.9 \%$ subcutaneously. Animals were placed carefully in a heated cage to control body temperature and given moistened, soft pellets in a Petri dish placed in the cages to encourage eating.

Collecting brains and plasma for steroid profiling by GC-MS/MS Mice were housed in a temperature-controlled room on a $12 \mathrm{~h}$ light/12 h dark cycle (lights on from 8:00 A.M. to 8:00 P.M.). For plasma and brain sampling, mice were handled gently to minimize stress and were quickly decapitated by rapid cervical dislocation without anesthesia. The brain was dissected out and the hemispheres were separated and quickly frozen on dry ice and stored at $-80^{\circ} \mathrm{C}$ until steroid level analysis by GC-MS/MS

\section{Experimental groups}

Set 1 . Set 1 was designed to evaluate the effect of ischemia on steroid levels. C57BL/6 young adult male and female mice (3 months old) were purchased from Janvier and were included in the experimental set after 1 week of acclimatization. Female mice were used at their diestrus phase. The estrus cycle was monitored between 9:00 and 10:00 A.M. by the examination of vaginal smears in a large group of intact young adult females. The adopted nomenclature was proestrus, estrus, metestrus, and diestrus according to the percentage of different cell types present as follows: proestrus (a majority of nucleated epithelial cells), estrus (a majority of cornified epithelial cells), metestrus (cornified epithelial cells and leukocytes), and diestrus (a majority of leukocytes) (Byers et al., 2012). The estrus cycle stage was checked in all females and those in diestrus were selected to constitute experimental groups of that day.

Twelve mice ( 6 males and 6 females) were used as controls to provide reference values for brain steroid levels in intact C57BL/6 mice. A total of $100 \mathrm{C} 57 \mathrm{BL} / 6$ mice (50 males and 50 females) were subjected to MCAO for $30 \mathrm{~min}$. Sets of 20 mice (10 males and 10 females) were killed at 1, 2, 4,6 , and $24 \mathrm{~h}$ after MCAO.

Set 2 . Set 2 was designed to evaluate the effects of neural PR deletion on steroid levels in both sexes. Young adult male PR ${ }^{\text {loxP/loxP }}$ and $\mathrm{PR}^{\text {NesCre }}$ mice on a C57BL/6 background (3-4 months old, $26-30 \mathrm{~g}, n=6$ per group) and young adult female $\mathrm{PR}^{\text {loxP/loxP }}$ and $\mathrm{PR}^{\text {Nescre }}$ mice (3-4 months old, 21-26 g, diestrus phase, $n=6$ per group) were used. The estrus cycle stage was checked in all females and those in diestrus were selected to constitute experimental groups of that day.

Set 3. Set 3 was designed to evaluate the effect of neural PR deletion and $\mathrm{MCAO}$ on steroid levels. Young adult male PR ${ }^{\text {loxP/loxP }}$ and $P R^{\text {NesCre }}$ mice (3-4 months old, $26-30 \mathrm{~g}, n=9$ per group), young adult female $\mathrm{PR}^{\text {loxP/loxP }}$ and $\mathrm{PR}^{\text {NesCre }}$ mice (3-4 months old, 21-26 g, diestrus phase, $n=9$ per group) were subjected to $30 \mathrm{~min}$ of MCAO (Gibson and Murphy, 2004) or sham operation.

\section{Steroid measurements by GC-MS/MS}

Steroids were extracted from plasma and the left hemisphere (180-240 $\mathrm{mg}$ ) of brain with methanol and the following internal standards were added to the extracts for steroid quantification: 2 ng of ${ }^{2} \mathrm{H}_{6}-5 \alpha$-DHP (CDN Isotopes) for the analysis of $5 \alpha / \beta$-dihydroprogesterone ( $5 \alpha / \beta$-DHP); $2 \mathrm{ng}$ of ${ }^{13} \mathrm{C}_{3}$-testosterone (Isoscience) for the analysis of testosterone; $2 \mathrm{ng}$ of ${ }^{13} \mathrm{C}_{3}$-androstenedione for the analysis of androstenedione; $2 \mathrm{ng}$ of ${ }^{13} \mathrm{C}_{3}$ progesterone for the analysis of progesterone; $2 \mathrm{ng}$ of ${ }^{13} \mathrm{C}_{3}-17 \beta$-estradiol for the analysis of $17 \beta$-estradiol, ${ }^{2} \mathrm{H}_{13}$-deoxycorticosterone (DOC) for the analysis of DOC; $2 \mathrm{ng}$ of 19 nor-PROG for the analysis of $20 \alpha$-DHP and $5 \alpha / \beta$-dihydrodeoxycorticosterone; $2 \mathrm{ng}$ of epietiocholanolone (Steraloids) for the analysis of $\alpha$-DHT; $3 \alpha 5 \alpha$-tetrahydrotestosterone, pregnenolone, $20 \alpha$-dihydropregnenolone, $3 \alpha / \beta 5 \alpha / \beta$-tetrahydroprogesterone, $5 \alpha 20 \alpha$-tetrahydroprogesterone, $3 \alpha / \beta 5 \alpha / \beta$-hexahydroprogesterone, and $3 \alpha 5 \alpha / \beta$-tetrahydrodeoxycorticosterone, and ${ }^{2} \mathrm{H}_{8}$-corticosterone for the analysis of corticosterone. Samples were purified and fractionated 
Table 1. GC-MS/MS parameters for steroid identification and quantification in multiple reaction monitoring

\begin{tabular}{|c|c|c|c|c|}
\hline Steroid (mol wt) & Derivatized steroid (mol wt) & Retention time (min) & Transition $(\mathrm{m} / \mathrm{z} \rightarrow \mathrm{m} / \mathrm{z})$ & Collision energy (eV) \\
\hline Pregnenolone (316) & Pregnenolone-3-HFB (512) & 21.24 & $298 \rightarrow 283$ & 8 \\
\hline$P(314)$ & P-3-HFB (510) & 21.34 & $510 \rightarrow 425$ & 14 \\
\hline $5 \alpha-\mathrm{DHP}(316)$ & $5 \alpha$-DHP-3,20-TMS 2 (460) & 18.63 & $460 \rightarrow 425$ & 12 \\
\hline $5 \beta$-DHP (316) & $5 \beta$-DHP-3,20-TMS 2 (460) & 17.30 & $460 \rightarrow 445$ & 10 \\
\hline $3 \alpha 5 \alpha$-THP (318) & $3 \alpha 5 \alpha$-THP-3-HFB (514) & 20.23 & $429 \rightarrow 215$ & 8 \\
\hline $3 \beta 5 \alpha$-THP (318) & $3 \beta 5 \alpha-$-ТНP-3-HFB (514) & 21.62 & $429 \rightarrow 215$ & 8 \\
\hline $3 \alpha 5 \beta$-THP (318) & $3 \alpha 5 \beta$-ТНP-3-HFВ (514) & 20.39 & $496 \rightarrow 481$ & 12 \\
\hline $20 \alpha-\mathrm{DHP}(316)$ & $20 \alpha-$ DHP-3,20-HFB 2 (708) & 18.48 & $708 \rightarrow 693$ & 10 \\
\hline $5 \alpha 20 \alpha-\operatorname{THP}(318)$ & $5 \alpha 20 \alpha$-ТНP-3-НFВ (514) & 22.93 & $514 \rightarrow 499$ & 8 \\
\hline $3 \alpha 5 \alpha 20 \alpha-\mathrm{HHP}(320)$ & $3 \alpha 5 \alpha 20 \alpha-$ HHP-3,20-HFВ 2 (712) & 17.40 & $712 \rightarrow 429$ & 8 \\
\hline $3 \beta 5 \alpha 20 \alpha-\operatorname{HHP}(320)$ & $3 \beta 5 \alpha 20 \alpha$-HHP-3,20-HFB 2 (712) & 18.75 & $697 \rightarrow 483$ & 10 \\
\hline $3 \alpha 5 \beta 20 \alpha-\mathrm{HHP}(320)$ & $3 \alpha 5 \beta 20 \alpha-H H P-3,20-\mathrm{HFB}_{2}(712)$ & 17.59 & $712 \rightarrow 429$ & 8 \\
\hline $20 \alpha$-DHPREG (318) & $20 \alpha$-DHPREG-3,20-HFB $2(710)$ & 18.00 & $496 \rightarrow 211$ & 10 \\
\hline Testosterone (288) & Testosterone-3,17-HFB 2 (680) & 15.98 & $680 \rightarrow 320$ & 8 \\
\hline $5 \alpha$-DHT (290) & $5 \alpha-$ DHT-17-HFB (486) & 20.16 & $486 \rightarrow 414$ & 10 \\
\hline $3 \alpha 5 \alpha$-ТНT (292) & $3 \alpha 5 \alpha-$ THT-3,17-HFB $2(684)$ & 15.00 & $470 \rightarrow 455$ & 8 \\
\hline $17 \beta$-estradiol (272) & $17 \beta$-estradiol-3,17-HFB 2 (664) & 16.60 & $664 \rightarrow 237$ & 10 \\
\hline DOC (330) & $\mathrm{DOC}-3,21-\mathrm{HFB}_{2}(722)$ & 21.80 & $722 \rightarrow 707$ & 10 \\
\hline $5 \alpha-\mathrm{DHDOC}(332)$ & $5 \alpha$-DHDOC-3,21-HFB (528) & 25.55 & $301 \rightarrow 273$ & 8 \\
\hline $5 \beta$-DHDOC (332) & $5 \beta$-DHDOC-3,21-HFB (528) & 25.23 & $301 \rightarrow 255$ & 8 \\
\hline $3 \alpha 5 \alpha$-THDOC (334) & $3 \alpha 5 \alpha$-THDOC-3,17-HFB 2 (726) & 20.69 & $499 \rightarrow 257$ & 8 \\
\hline $3 \alpha 5 \beta$-THDOC (334) & $3 \alpha 5 \beta$-THDOC-3,17-HFB & 20.83 & $499 \rightarrow 257$ & 10 \\
\hline Corticosterone (346) & Corticosterone-3,21- $\mathrm{HFB}_{2}-\mathrm{H}_{2} \mathrm{O}(720)$ & 20.31 & $705 \rightarrow 355$ & 10 \\
\hline
\end{tabular}

Steroids were identified according to their retention time and their specific transition. Transitions were performed by selecting a precursor ion of a targeted steroid by the first mass spectrometer. This precursor ion was then fragmented at a collision energy chosen to give rise to a maximal signal of the product ion analyzed by the second mass spectrometer. The quantification was determined by the transition giving the most abundant product ion. P, Progesterone; DHP, dihydroprogesterone; THP, tetrahydroprogesterone; HHP, hexahydroprogesterone; DHPREG, dihydropregnenolone; DHT, dihydrotestosterone; THT, tetrahydrotestosterone; DOC, 11-deoxycorticosterone; DHDOC, dihydro-11-deoxycorticosterone; THDOC, tetrahydro-11-deoxycorticosterone; HFB, heptafluorobutyrate; TMS, trimethylsilyl.

by solid-phase extraction with the recycling procedure (Liere et al., 2004). Briefly, the extracts were dissolved in $1 \mathrm{ml}$ of methanol and applied to the $\mathrm{C} 18$ cartridge $(500 \mathrm{mg}, 6 \mathrm{ml}$; International Sorbent Technology), followed by $5 \mathrm{ml}$ of methanol/ $\mathrm{H}_{2} \mathrm{O}(85 / 15)$. The flow-through containing the free steroids was collected and dried. After a previous reconditioning of the same cartridge with $5 \mathrm{ml}$ of $\mathrm{H}_{2} \mathrm{O}$, the dried samples were dissolved in methanol/ $\mathrm{H}_{2} \mathrm{O}(2 / 8)$ and reapplied. The cartridge was then washed with $5 \mathrm{ml}$ of $\mathrm{H}_{2} \mathrm{O}$ and $5 \mathrm{ml}$ of methanol/ $\mathrm{H}_{2} \mathrm{O}(1 / 1)$ and unconjugated steroids were eluted with $5 \mathrm{ml}$ of methanol/ $\mathrm{H}_{2} \mathrm{O}(9 / 1)$.

The unconjugated steroid-containing fraction was then filtered and further purified and fractionated by HPLC. The HPLC system was composed of a WPS-3000SL analytical autosampler and a LPG-3400SD quaternary pump gradient coupled with a SR-3000 fraction collector (Thermo Fisher Scientific). The HPLC separation was achieved with a Lichrosorb Diol column $(25 \mathrm{~cm}, 4.6 \mathrm{~mm}, 5 \mu \mathrm{m})$ and a thermostatic block at $30^{\circ} \mathrm{C}$. The column was equilibrated in a solvent system of $90 \%$ hexane and $10 \%$ of a mixture composed of hexane/isopropanol (85/15). Elution was performed at a flo -rate of $1 \mathrm{ml} / \mathrm{min}$, first $90 \%$ hexane and $10 \%$ of hexane/isopropanol $(85 / 15)$ for $8 \mathrm{~min}$, then with a linear gradient to $100 \%$ of hexane/isopropanol (85/15) in $2 \mathrm{~min}$. This mobile phase was kept constant for $10 \mathrm{~min}$ and a linear gradient to $100 \%$ methanol was applied. The column was washed with methanol for $15 \mathrm{~min}$.

Three fractions were collected from the HPLC system: $5 \alpha / \beta$-DHPROG was eluted in the first HPLC fraction (3-13 min) and was silylated with $50 \mu \mathrm{l}$ of a mixture $N$-methyl- $N$-trimethylsilyltrifluoroacetamide/ammonium iodide/dithioerythritol (1000:2:5 vol/w/w) for $15 \mathrm{~min}$ at $70^{\circ} \mathrm{C}$. The second fraction (13-25 min) containing pregnenolone, $20 \alpha$-dihydropregnenolone, progesterone, deoxycorticosterone, testosterone, and their reduced metabolites and $17 \beta$-estradiol was derivatized with $25 \mu \mathrm{l}$ of heptafluorobutyric anhydride (HFBA) and $25 \mu$ lof anhydrous acetone for $1 \mathrm{~h} 20^{\circ} \mathrm{C}$. Corticosterone was eluted in the third fraction (25-33 min) and derivatized with $25 \mu \mathrm{l}$ of HFBA and $25 \mu \mathrm{l}$ of anhydrous acetone for $1 \mathrm{~h}$ at $80^{\circ} \mathrm{C}$. All fractions were dried under a stream of $\mathrm{N}_{2}$ and resuspended in hexane for GC-MS/MS analysis.

GC-MS/MS analysis of the brain extracts was performed using an AI 1310 autosampler, a Trace 1310 GC, and a TSQ 8000 MS/MS (Thermo Fisher Scientific) using argon as the collision gas. Injection was performed in the splitless mode at $250^{\circ} \mathrm{C}$ ( 1 min of splitless time) and the
Table 2. Validation of the GC-MS/MS analytical procedure in mouse brain

\begin{tabular}{|c|c|c|c|c|}
\hline Steroid (mol wt) & $\begin{array}{l}\text { Detection } \\
\text { limit }(\mathrm{pg} / \mathrm{g})\end{array}$ & Accuracy (\%) & $\begin{array}{l}\text { Intra-assay } \\
\text { variation (\%) }\end{array}$ & $\begin{array}{l}\text { Inter-assay } \\
\text { variation (\%) }\end{array}$ \\
\hline Pregnenolone (316) & 2 & 102.9 & 5.1 & 5.5 \\
\hline$P(314)$ & 20 & 105.9 & 2.2 & 3.6 \\
\hline $5 \alpha-\mathrm{DHP}(316)$ & 5 & 101.3 & 3.2 & 4.8 \\
\hline $5 \beta$-DHP (316) & 2 & 103.4 & 3.6 & 6.8 \\
\hline $3 \alpha 5 \alpha$-THP (318) & 10 & 97.5 & 5.4 & 7.4 \\
\hline $3 \beta 5 \alpha-\operatorname{THP}(318)$ & 0.5 & 99.6 & 4.5 & 5.6 \\
\hline $3 \alpha 5 \beta$-ТНP (318) & 10 & 105.1 & 6.2 & 6.5 \\
\hline $20 \alpha-\mathrm{DHP}(316)$ & 10 & 103.6 & 8.2 & 9.2 \\
\hline $5 \alpha 20 \alpha-\operatorname{THP}(318)$ & 1 & 106.2 & 4.3 & 5.1 \\
\hline $3 \alpha 5 \alpha 20 \alpha-\mathrm{HHP}(320)$ & 5 & 98.4 & 3.2 & 3.5 \\
\hline $3 \beta 5 \alpha 20 \alpha-\mathrm{HHP}(320)$ & 5 & 99.6 & 2.9 & 3.0 \\
\hline $3 \alpha 5 \beta 20 \alpha-\mathrm{HHP}(320)$ & 5 & 95.3 & 2.6 & 2.7 \\
\hline $20 \alpha$-DHPREG (318) & 1 & 107.1 & 1.5 & 2.5 \\
\hline Testosterone (288) & 1 & 99.8 & 1.1 & 1.8 \\
\hline $5 \alpha$-DHT (290) & 2 & 101.4 & 3.9 & 4.3 \\
\hline $3 \alpha 5 \alpha$-ТНT (292) & 1 & 102.6 & 3.6 & 4.9 \\
\hline 17 $\beta$-estradiol (272) & 1 & 96.4 & 1.3 & 1.9 \\
\hline DOC (330) & 5 & 98.2 & 1.5 & 1.7 \\
\hline $5 \alpha-\mathrm{DHDOC}(332)$ & 5 & 102.6 & 5.4 & 5.8 \\
\hline $5 \beta$-DHDOC (332) & 5 & 104.5 & 6.1 & 6.9 \\
\hline $3 \alpha 5 \alpha$-THDOC (334) & 2 & 10.10 .4 & 4.9 & 6.1 \\
\hline $3 \alpha 5 \beta$-THDOC (334) & 2 & 98.2 & 3.4 & 4.0 \\
\hline Corticosterone (346) & 20 & 97.6 & 2.5 & 3.0 \\
\hline
\end{tabular}

The analytical protocol has been validated for all targeted steroids using $200 \mathrm{mg}$ extracts from a pool of male mouse brains. The limit of detection was determined as the lowest amount of compounds that could be measured by GC-MS/MS with a signal-to-noise ratio $>3$. The linearity was assessed by analyzing increasing amounts of mouse brain extracts $(20,50,100$, and $200 \mathrm{mg})$ in triplicate with a coefficient of correlation ranging from 0.992 to 0.999 . The accuracy of the assay was evaluated by determining the analytical recovery, which was defined as $C /\left(C_{0}+S\right) \times$ $100(\%)$, where $C$ is the concentration of the steroid in the spiked brain extract $(200 \mathrm{mg}), C_{0}$ is the concentration of a steroid in the unspiked brain extract $(200 \mathrm{mg})$, and $S$ is the spiked concentration. The precision of the intra-assays and inter-assays were evaluated by analyzing 5 replicates of $200 \mathrm{mg}$ brain extracts on $1 \mathrm{~d}$ and over $4 \mathrm{~d}$, respectively. Abbreviations of steroids are as for Table 1. 
A Pregnenolone

Brain

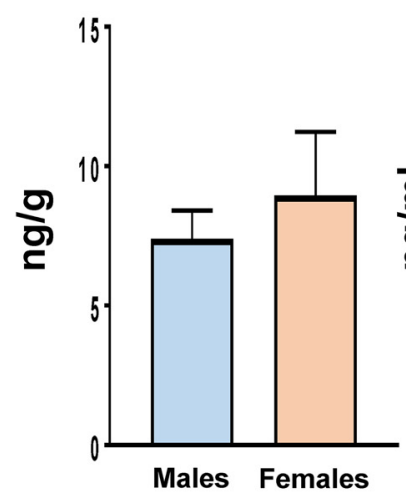

C

5a-DHP
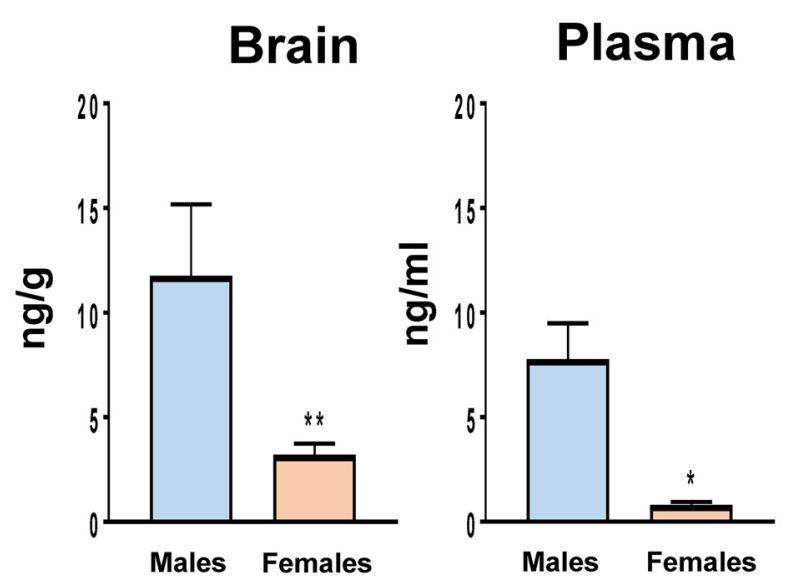

E

$20 \alpha-D H P$
Plasma

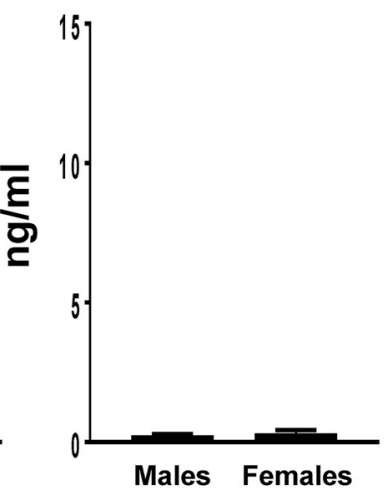

Males Females
B

Progesterone
Brain

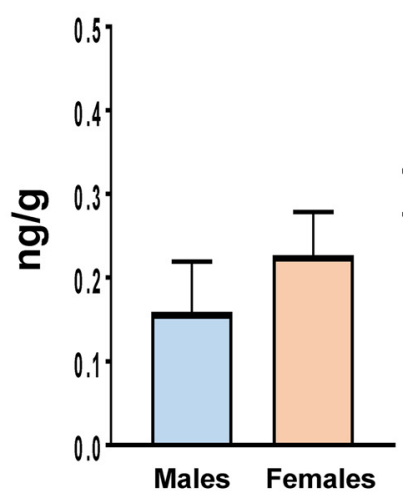

Plasma

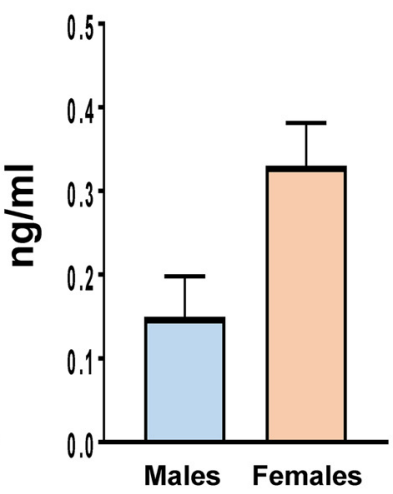

D $\quad 3 \alpha, 5 \alpha-T H P$

Plasma
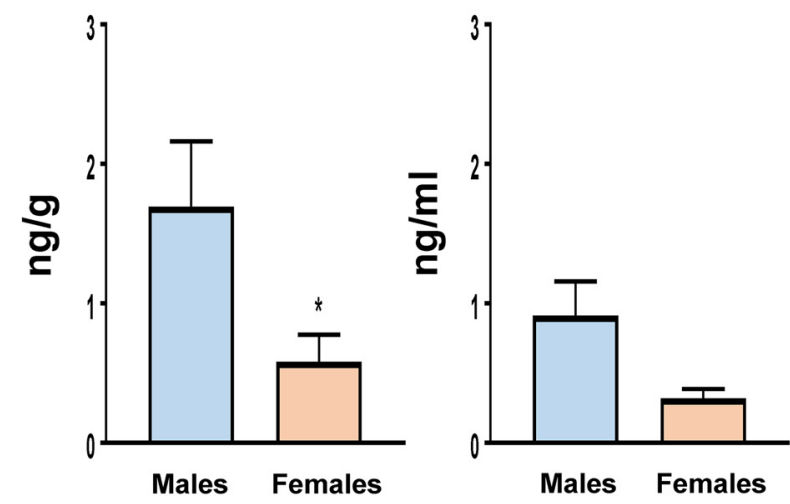

$\mathbf{F}$
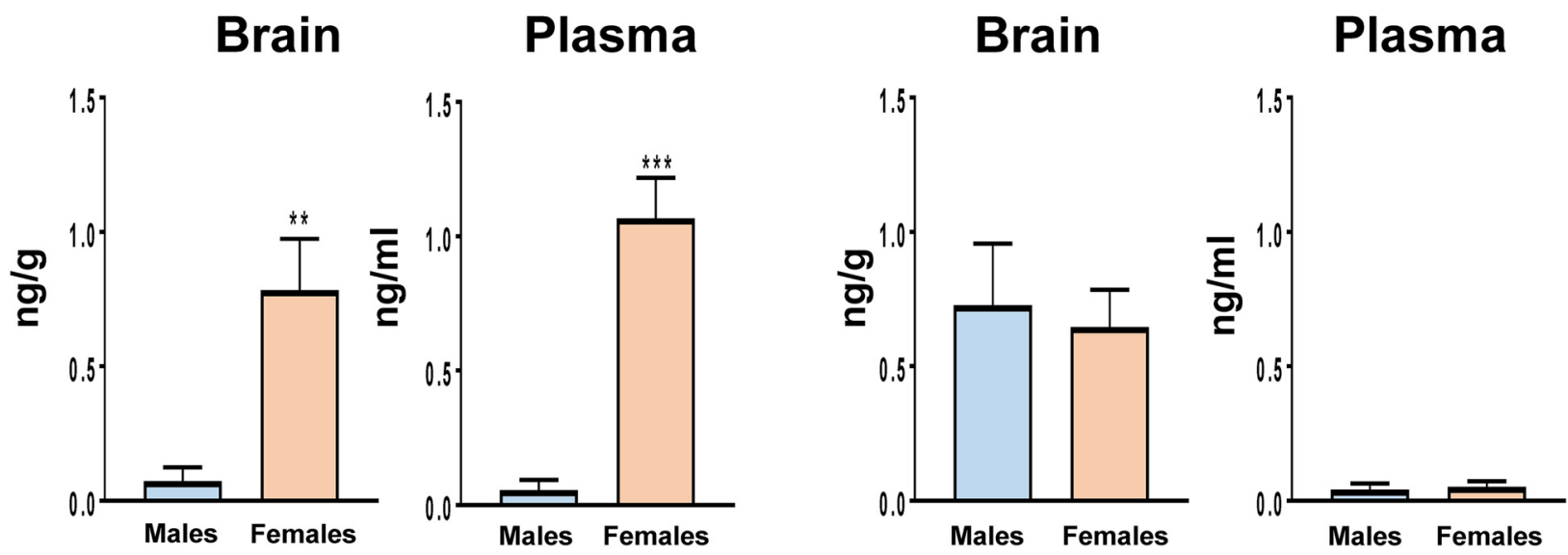

Figure 2. Levels of pregnenolone and progesterone and its major metabolites were analyzed by GC-MS/MS in the left brain hemisphere and plasma of young adult males and diestrus females (for an extended steroid profiling, see Table 3). $\boldsymbol{A}$, Levels of pregnenolone were higher in the brains of males and females than in plasma (effect of tissue: $\left.F_{(1,29)}=27.5, p<0.0001\right)$. $\boldsymbol{B}$, Levels of progesterone were similar in brain and plasma of both sexes (effect of tissue: $p=0.4$ ). In plasma, levels of progesterone were higher in females than in males (Figure legend continues.) 
temperature of the GC oven was initially maintained at $50^{\circ} \mathrm{C}$ for $1 \mathrm{~min}$ and ramped between $50^{\circ} \mathrm{C}$ and $200^{\circ} \mathrm{C}$ at $20^{\circ} \mathrm{C} / \mathrm{min}$, then ramped to $300^{\circ} \mathrm{C}$ at $5^{\circ} \mathrm{C} / \mathrm{min}$, and finally ramped to $350^{\circ} \mathrm{C}$ at $30^{\circ} \mathrm{C} / \mathrm{min}$. The helium carrier gas flow was maintained constant at $1 \mathrm{ml} / \mathrm{min}$ during the analysis. The transfer line and ionization chamber temperatures were $330^{\circ} \mathrm{C}$ and $180^{\circ} \mathrm{C}$, respectively. Electron impact ionization was used for mass spectrometry with ionization energy of $70 \mathrm{eV}$. GC-MS/MS signals were evaluated using a computer workstation by means of the software Excalibur, release 3.0 (Thermo Fisher Scientific). Identification of steroids was supported by their retention time and according to two or three transitions. Quantification was performed according to the transition giving the more abundant product ion (Table 1 ) with a previously established calibration curve.

The analytical protocol has been validated for all the targeted steroids using extracts of $200 \mathrm{mg}$ of from a pool of male mice brain. The evaluation included the limit of detection, linearity, accuracy, intra-assay, and inter-assay precision (Table 2). The limit of detection was determined as the lowest amount of compounds that can be measured by GC-MS/MS with a signal-to-noise ratio $>3$ and ranged from 0.5 to $20 \mathrm{pg} / \mathrm{g}$. The linearity was assessed by analyzing increasing amounts of mouse brain extracts $(20,50,100$, and $200 \mathrm{mg})$ in triplicate. The linearity was satisfactory for all the steroids with a coefficient of correlation ranging from 0.992 to 0.999 . The accuracy of the assay was evaluated by determining the analytical recovery, which was defined as $C /\left(C_{0}+S\right) \times 100(\%)$, where $C$ is the concentration of the steroid in the spiked brain extract $(100 \mathrm{mg}), C_{0}$ is the concentration of a steroid in the unspiked brain extract $(100 \mathrm{mg})$, and $S$ is the spiked concentration. The precision of the intra-assays and inter-assays were evaluated by analyzing 5 replicates of $200 \mathrm{mg}$ of brain extracts on $1 \mathrm{~d}$ and over $4 \mathrm{~d}$, respectively.

\section{Quantitative RT-PCR analysis of PR mRNA expression}

Young adult male and female (4 months old) wild-type (WT) $\mathrm{PR}^{+/+}$ (C57BL/6), $\mathrm{PR}^{\text {loxP/loxP }}$, and $\mathrm{PR}^{\mathrm{Nes} C r e}$ mice $(n=4$ per group) were used. Brains minus cerebellum were dissected out and separated into three regions: hypothalamus, cortex, and subcortical regions (all the remaining tissue). Peripheral tissues expressing PRs (http://www.nursa.org) were also collected: aorta, kidney, and thymus from males and uterus, ovaries, and mammary glands from females. Samples were quickly frozen on dry ice and stored at $-80^{\circ} \mathrm{C}$. Total RNA was isolated from tissue samples using the RNeasy Lipid Tissue Mini Kit (Qiagen) following the manufacturer's instructions. cDNA templates were synthesized using a SuperScript II ribonuclease $\mathrm{H}$ reverse transcriptase kit (Invitrogen). Primers for PR were chosen in exon 2 of PR gene. Cyclophilin 3 (Cyc3) was chosen as the housekeeping gene. Primers were designed using Primer Express version 3.0, Applied Biosystems as follows: PR F: 5'-TTACCTGT GGGAGCTGCAAG-3'; PR R: 5'-ATGCCAGCCTGACAACACTT-3'; Cyc3 F: 5'-CCTGGCT GGGTGAGCATGGC-3'; Cyc3 R: 5'-CAGTGG CTTGTCCCGGCTGT-3'). The relative PR mRNA expression was determined by real-time quantitative PCR using the ABI Prism 7300 sequence detection system (Applied Biosystems) and $2^{-\triangle \triangle C T}$ method (Livak and Schmittgen, 2001). Correlation coefficient $\left(r^{2}\right)$ and efficiency (Ex) of PCR amplification were calculated before quantification (Pein-

(Figure legend continued.) (effect of sex: $\left.F_{(1,25)}=4.74, p<0.05\right)$. C, Levels of $5 \alpha$-DHP were higher in males than in females for brain and plasma (effect of sex: $F_{(1,27)}=20.6, p<0.001$ ). Levels of $5 \alpha$-DHP tended to be higher in brain compared with plasma (effect of tissue: $F_{(1,27)}=$ $3.51, p=0.072)$. $\boldsymbol{D}$, Brain and plasma levels of $3 \alpha, 5 \alpha$-THP were higher in males compared with females (effect of sex: $\left.F_{(1,27)}=8.71, p<0.01\right)$. Moreover, levels of $3 \alpha, 5 \alpha$-THP tended to be higher in brain compared with plasma (effect of tissue: $\left.F_{(1,27)}=3.26, p=0.082\right)$. $E$, In contrast to the $5 \alpha$-reduced 20-keto-pregnanes, levels of $20 \alpha$-DHP were higher in brain and plasma of females (effect of sex: $F_{(1,25)}=33.1, p<0.0001$ ). Levels of $20 \alpha$-DHP did not differ between brain and plasma. $F$, In the brain, $20 \alpha$-DHP was converted to $5 \alpha, 20 \alpha$-THP. In plasma, levels of $5 \alpha, 20 \alpha$-THP were very low ( $40-50 \mathrm{pg} / \mathrm{ml}$; effect of tissue: $\left.F_{(1,24)}=19.0, p<0.001\right)$. Results are presented as means \pm SEM ( $n=5-6$ per group) and were analyzed by two-way ANOVA (sex $\times$ tissue) followed by Newman-Keuls multiple-comparisons tests. ${ }^{* *} p<0.001$, ${ }^{* *} p<0.01,{ }^{*} p<0.05$ compared with males or as indicated.
}

Table 3. Steroid profiling in brain (left hemisphere) and plasma of young adult C57BL6 mice of both sexes

\begin{tabular}{llllll}
\hline & \multicolumn{2}{l}{ Left hemisphere $(\mathrm{ng} / \mathrm{g})$} & & \multicolumn{2}{l}{ Plasma $(\mathrm{ng} / \mathrm{ml})$} \\
\cline { 2 - 3 } \cline { 5 - 6 } Steroid & Males & Females & & Males & Females \\
\hline $5 \beta$-DHP & $0.09 \pm 0.08$ & $0.14 \pm 0.08$ & & $0.02 \pm 0.01$ & $0.02 \pm 0.01$ \\
$3 \beta 5 \alpha$-THP & $0.36 \pm 0.11$ & $0.09 \pm 0.04^{* *}$ & & $0.01 \pm 0.003$ & $0.02 \pm 0.004$ \\
$3 \alpha 5 \beta$-THP & $0.09 \pm 0.03$ & $0.12 \pm 0.07$ & & $0.07 \pm 0.02$ & $0.33 \pm 0.07^{*}$ \\
$3 \alpha 5 \alpha 20 \alpha$-HHP & $0.39 \pm 0.15$ & $0.68 \pm 0.15$ & & $0.18 \pm 0.10$ & $0.32 \pm 0.07$ \\
$3 \beta 5 \alpha 20 \alpha$-HHP & $0.03 \pm 0.02$ & $0.04 \pm 0.02$ & & $0.01 \pm 0.003$ & $0.04 \pm 0.01$ \\
$3 \alpha 5 \beta 20 \alpha$-HHP & $0.01 \pm 0.003$ & $0.07 \pm 0.04$ & & $0.03 \pm 0.02$ & $0.06 \pm 0.02$ \\
$20 \alpha$-DHPREG & $0.13 \pm 0.02$ & $0.14 \pm 0.03$ & & $0.01 \pm 0.005$ & $0.02 \pm 0.01$ \\
DOC & $0.02 \pm 0.01$ & $0.11 \pm 0.03$ & & $0.28 \pm 0.13$ & $0.20 \pm 0.07$ \\
$5 \alpha$-DHDOC & $0.23 \pm 0.04$ & $0.06 \pm 0.01^{*}$ & & $0.20 \pm 0.06$ & $0.09 \pm 0.03^{*}$ \\
$5 \beta$-DHDOC & $0.01 \pm 0.01$ & $0.21 \pm 0.08$ & & $0.02 \pm 0.0002$ & $0.21 \pm 0.07$ \\
$3 \alpha 5 \alpha$-THDOC & $0.11 \pm 0.03$ & $0.02 \pm 0.011^{*}$ & & $0.11 \pm 0.05$ & $0.03 \pm 0.01$ \\
$3 \alpha 5 \beta$-THDOC & $0.01 \pm 0.01$ & $0.15 \pm 0.06$ & & $0.01 \pm 0.01$ & $0.39 \pm 0.17$ \\
Corticosterone & $3.76 \pm 1.00$ & $1.40 \pm 0.33$ & & $10.2 \pm 4.71$ & $21.5 \pm 5.99^{*}$ \\
Testosterone & $1.21 \pm 0.39$ & $0.02 \pm 0.01$ & & $2.16 \pm 0.87$ & $0.01 \pm 0.003^{*}$ \\
$5 \alpha$-DHT & $0.19 \pm 0.06$ & $0.02 \pm 0.01^{* *}$ & & $0.08 \pm 0.02$ & $0.01 \pm 0.002$ \\
$3 \alpha 5 \alpha$-THT & $0.16 \pm 0.05$ & ND & & $0.25 \pm 0.06$ & ND \\
Estradiol & $0.04 \pm 0.01$ & $0.02 \pm 0.01$ & & $0.02 \pm 0.01$ & $0.03 \pm 0.01$ \\
\hline
\end{tabular}

Results are presented as means $\pm \operatorname{SEM}(n=6-10$ per group) and were analyzed by two-way ANOVA (tissue $\times$ sex) followed by Newman-Keuls multiple-comparisons tests.

${ }^{* *} p<0.01,{ }^{*} p<0.05$ compared with males.

Abbreviations of steroids are as for Table 1. ND, Not detected.

nequin et al., 2004) as follows PR: $\mathrm{Ex}=0.90 ; r^{2}=0.999 ; \mathrm{Cyc} 3: \mathrm{Ex}=0.96$; $r^{2}=0.997$.

\section{Immunofluorescence and confocal analyses of $P R$}

protein expression

Male and female ( 3 months old) $\mathrm{PR}^{\text {loxP/loxP }}$ and $\mathrm{PR}^{\text {NesCre }}$ mice $(n=3$ per group) were injected with estradiol benzoate in sesame oil $(10 \mu \mathrm{g} / \mathrm{kg} / \mathrm{d}$, s.c., $2 \mathrm{~d}$ ). This dose and duration of treatment have been shown to induce PR expression (Brown et al., 1987). Animals were anesthetized with ketamine and perfused through the heart with PBS followed by $4 \%$ paraformaldehyde. Brains and uteri were dissected out and postfixed in the same fixative overnight. Tissue samples were cut into $50 \mu \mathrm{m}$ slices using Vibratome and stored in PBS azide $0.05 \%$ at $4^{\circ} \mathrm{C}$. To detect PR protein, immunofluorescence analysis was performed on free-floating sections using a rabbit polyclonal antibody (A0098; DAKO) directed against the DNA-binding domain of the human PR. This antibody was raised against a peptide sequence (aa 533-547) present in both the A and B isoforms of PRs (Traish and Wotiz, 1990). Slices were washed three times in PBS $1 \times$; pH 7.6 (5 min each), incubated in PBS $1 \times$ containing $3 \%$ normal goat serum (NGS, Sigma-Aldrich) and $0.5 \%$ Triton (20 min at room temperature, RT), and then incubated with anti-PR antibody $1 / 500$ in PBS $1 \times$ containing $1 \% \mathrm{NGS}\left(72 \mathrm{~h}\right.$, at $\left.4^{\circ} \mathrm{C}\right)$. Sections were rinsed in PBS $1 \times$ and incubated for $2 \mathrm{~h}$ at RT with the fluorescent secondary antibody (goat anti-rabbit IgG Alexa Fluor 488, A11008; Invitrogen) diluted at 1:200 in PBS $1 \times$. Control of immunostaining was shown by substitution of the antibody by nonimmune serum on adjacent sections. In this case, no staining was observed. Sections were then rinsed with PBS $1 \times$ three times (5 min each) and mounted on slices using PBS/gelatin/azide/fluoromount. Labeling was visualized using a confocal Zeiss LSM 510 microscope. Sequences were acquired with green $(488 \mathrm{~nm})$ excitation.

\section{Outcomes at 6 h after transient MCAO}

Young adult male $\mathrm{PR}^{\text {loxP/loxP }}$ and $\mathrm{PR}^{\text {NesCre }}$ mice (3-4 months old, 26-30 g, $n=9$ per group), young adult female $\mathrm{PR}^{\text {loxP/loxP }}$ and PR ${ }^{\text {NesCre }}$ mice (3-4 months old, $21-26 \mathrm{~g}$, diestrus phase, $n=9$ per group), and aging $\mathrm{PR}^{\text {loxP/loxP }}$ and PR ${ }^{\text {NesCre }}$ male and female mice (12-14 months old, $n=$ 10 per group) were subjected to $30 \mathrm{~min}$ MCAO. Three died during surgery and a further four mice were excluded because of a $<70 \%$ drop in blood flow. Analysis was performed at $6 \mathrm{~h}$ after MCAO.

Infarct volumes (TTC staining). After cervical dislocation, brains were removed immediately and cut into $8 \times 1 \mathrm{~mm}$ coronal sections using a MacIlwain tissue chopper (Mickle Laboratory Engineering). To quantify 


\section{Males}
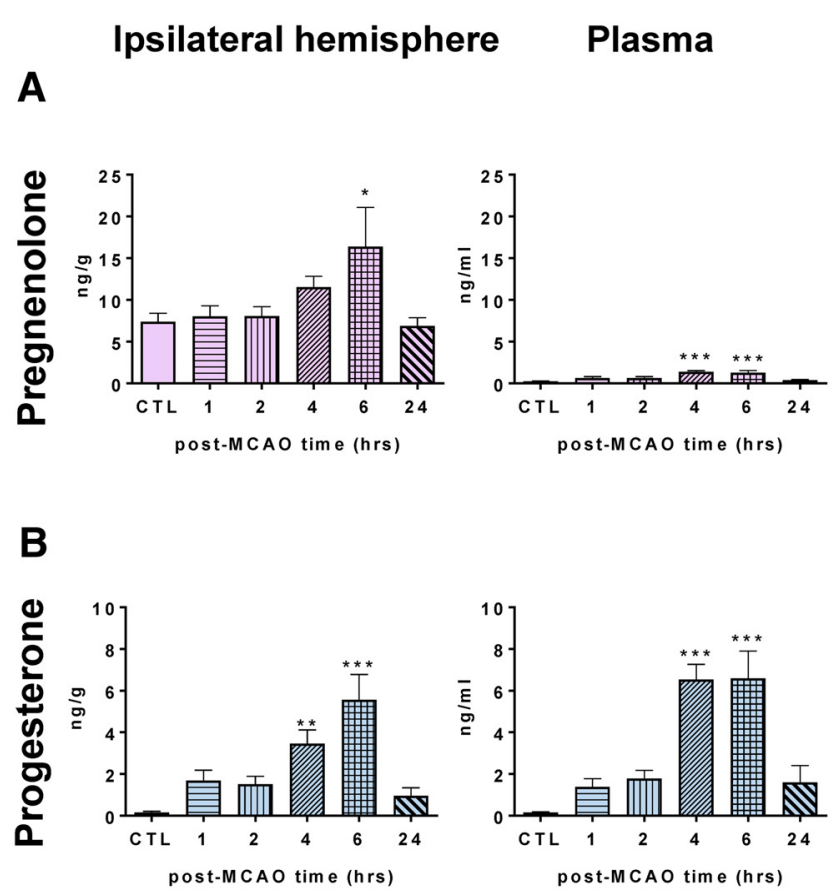

C
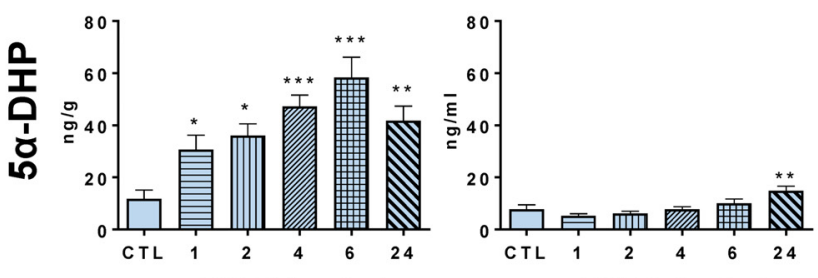

post-MCAO time (hrs)

post-MCAO time (hrs)

D
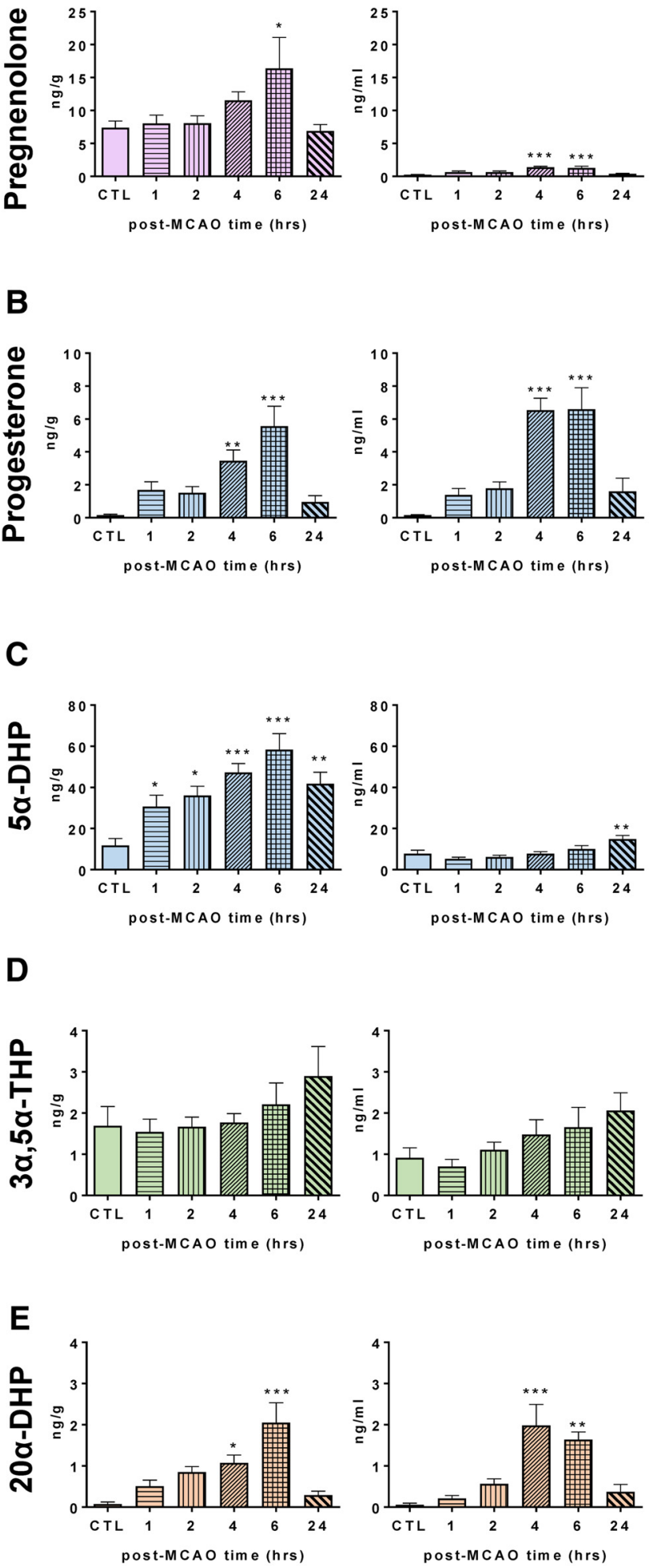
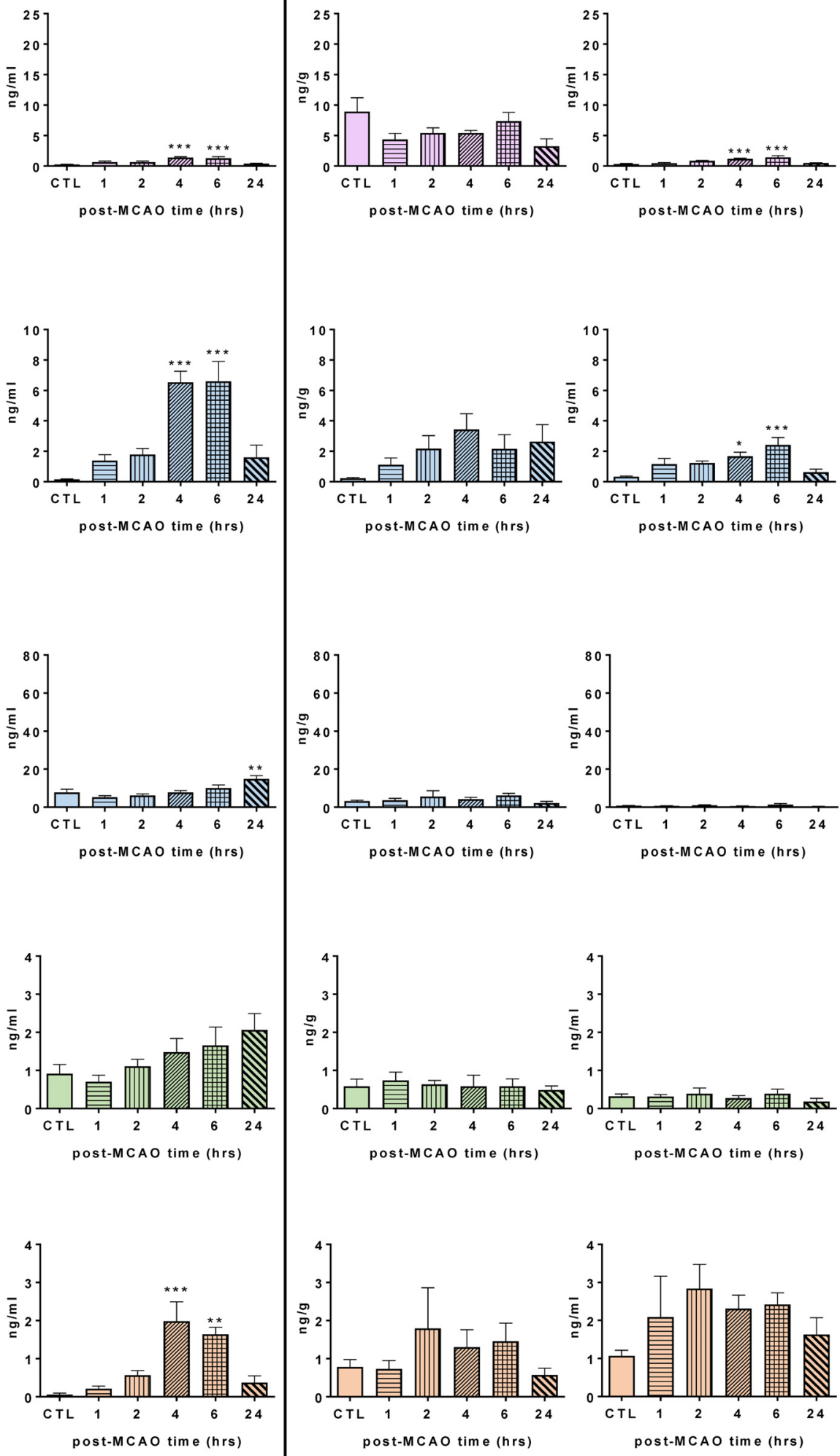

post-MCAO time (hrs)
Females

Plasma

Ipsilateral hemisphere

Figure 3. Levels of pregnenolone and progesterone and its major metabolites were analyzed by GC-MS/MS in the ipsilateral (left, ischemic) hemisphere and in plasma of young adult male and diestrus female mice at different times (hours) after MCAO (for an extended steroid profiling, see Table 4). $A$, In males, levels of pregnenolone were increased significantly in the ipsilateral hemisphere at $6 \mathrm{~h}$ after $\operatorname{MCAO}\left(F_{(5,46)}=3.0, p<0.05\right)$ and slightly in plasma at 4 and $6 \mathrm{~h}\left(F_{(5,37)}=8.3, p<0.001\right)$. As in males, plasma levels of $($ Figure legend continues.) 
the ischemic damage, slices were rapidly immersed into a $2 \% 2,3,5$ triphenyltetrazolium chloride (TTC; Sigma-Aldrich) solution for 15-20 min at room temperature (Türeyen et al., 2004). The brain slices were scanned and the area of damaged unstained brain tissues was measured on the posterior surface of each section using ImageJ $1.46 \mathrm{f}$ software. To correct for brain swelling, infarct volume of each mouse was multiplied by the ratio of the volume of intact contralateral hemisphere to ischemic ipsilateral hemisphere at the same level. Total infarct volume of damaged tissue, expressed in cubic millimeters, was calculated by linear integration of the corrected lesion areas (Golanov and Reis, 1995).

Neurological deficits (six-point neurological severity score). Neurological deficits of each mouse were evaluated as described previously (Gibson et al., 2011). An expanded 6-point neurologic severity score with the following scale was used: 0 , normal function without deficits; 1 , flexion and torsion of the contralateral forelimb when held by tail; 2 , circling to the ipsilateral side, but normal posture at rest; 3 , circling to the ipsilateral side; 4 , rolling to the ipsilateral side; and 5 , leaning to the ipsilateral side without spontaneous motor activity. The mean of each group was calculated.

Immunofluorescence analysis of neurons and microglia. After TTC staining, coronal brain slices $(+1 \mathrm{~mm}$, bregma and $-1 \mathrm{~mm})$ were selected. Brain sections were fixed with $4 \%$ PFA and cryoprotected in a series of $10 \%, 20 \%$, and $30 \%$ sucrose for $24 \mathrm{~h}$ per solution at $4^{\circ} \mathrm{C}$. Tissues were frozen in optimal cutting temperature medium (Sakura-Fineteck) and stored at $-20^{\circ} \mathrm{C}$. The frozen tissues were cut on the cryostat (HM 560; Thermo Fisher Scientific) to obtain serial coronal brain sections (14 $\mu \mathrm{m})$. The cryostat sections were washed with PBS $1 \times$ and blocked in $3 \%$ NGS for $20 \mathrm{~min}$ at room temperature and then incubated with the primary antibodies: rabbit anti-NeuN polyclonal antibody (1/500; Millipore) for the staining of neuronal nuclei and rabbit anti-Ibal antibody (1/100; WAKO), a marker for detecting microglia/macrophages, overnight at $4^{\circ} \mathrm{C}$. After rinsing in PBS $1 \times$, sections were incubated with secondary antibody (goat anti-rabbit) diluted 1:200 in PBS $1 \times$ for $2 \mathrm{~h}$. After 3 consecutive washes in PBS $1 \times$, the sections were stained for 15 $\min$ in $0.1 \mu \mathrm{g} / \mathrm{ml}$ DAPI. The slices were washed in PBS $1 \times 3$ times $(5 \mathrm{~min}$ each), dried, and coverslipped using Fluormount G (Southern Biotechnology). To show the specificity of the immunostaining, negative controls were processed using 3\% NGS in place of primary antibody. Immunofluorescence labeling was visualized using a Zeiss Axioimager microscope A1.

Photographs were obtained with objective $(20 \times)$ in the cortex and subcortex. Two sections/mouse were analyzed from each group. $\mathrm{NeuN}^{+}$

$\leftarrow$

(Figure legend continued.) pregnenolone were weakly but significantly increased in females at 4 and $6 \mathrm{~h}\left(F_{(5,28)}=10.7, p<0.001\right)$. Analysis by 2-way ANOVA (sex $\times$ time) indeed revealed a significant effect of $\operatorname{sex}\left(F_{(5,81)}=11.7, p<0.001\right)$. B, In males, progesterone was significantly increased at 4 and $6 \mathrm{~h}$ after MCAO both in the ipsilateral hemisphere $\left(F_{(5,46)}=9.67, p<\right.$ $0.0001)$ and in plasma $\left(F_{(5,35)}=11.4, p<0.0001\right)$. Analysis by 2 -way ANOVA (sex $\times$ time) of brain progesterone levels showed a significant effect of time $\left(F_{(5,80)}=7.94, p<0.0001\right)$ and a significant interaction between time and $\operatorname{sex}\left(F_{(5,80)}=3.20, p<0.05\right)$. Similarly, 2-way ANOVA analysis of plasma progesterone levels revealed a significant effect of time $\left(F_{(5,60)}=\right.$ $12.4, p<0.0001)$, a significant interaction between time and $\operatorname{sex}\left(F_{(5,60)}=4.64, p<0.001\right)$, and also an effect of $\operatorname{sex}\left(F_{(1,60)}=17.8, p<0.0001\right)$. $C$, In the male ipsilateral hemisphere, levels of $5 \alpha$-DHP increased continuously between 1 and $6 \mathrm{~h}$ after MCAO, and they were still elevated at $24 \mathrm{~h}\left(F_{(5,45)}=7.33 p<0.0001\right)$. Analysis by 2-way ANOVA (sex $\times$ time) of brain $5 \alpha$-DHP levels showed a significant effect of time $\left(F_{(5,79)}=7.05, p<0.0001\right)$, of sex $\left(F_{(1,79)}=\right.$ $158.7, p<0.0001)$ and a significant interaction between time and $\operatorname{sex}\left(F_{(5,79)}=5.80, p<\right.$ $0.0001)$. $\boldsymbol{D}$, Levels of $3 \alpha, 5 \alpha$-THP in brain and plasma were higher in males compared with females. This observation was supported by 2-way ANOVA (sex $\times$ time) for brain (effect of sex: $F_{(1,80)}=33.7, p<0.0001$ ) and plasma (effect of sex: $\left.F_{(1,62)}=29.1, p<0.0001\right)$. $\boldsymbol{E}$, In males, levels of $20 \alpha$-DHP were increased significantly in brain $\left(F_{(5,42)}=9.0, p<0.0001\right)$ and in plasma $\left(F_{(5,34)}=9.60, p<0.0001\right)$ at 4 and $6 \mathrm{~h}$ after MCAO. No significant changes over time were observed in females. A two-way ANOVA (sex $\times$ time) revealed a significant effect of sex for plasma levels of $20 \alpha$-DHP $\left(F_{(1,61)}=30.5, p<0.0001\right)$. Results are presented as means \pm SEM ( $n=5-10$ per group) and were analyzed by one-way ANOVA followed by Newman-Keuls multiple-comparisons tests. ${ }^{* * *} p<0.001,{ }^{* *} p<0.01,{ }^{*} p<0.05$ compared with the control (CTL). cells and $\mathrm{Ibal}^{+}$cells per area of $0.38 \mathrm{~mm}^{2}$ per section were counted. For each mouse, the total number of immune-positive cells in the 2 sections corresponding to an area of $0.76 \mathrm{~mm}^{2}$ was obtained. Data are expressed as means $\pm \mathrm{SEM}$ of $\mathrm{NeuN}^{+}$or $\mathrm{Ibal}^{+}$cells $/ \mathrm{mm}^{2}$.

\section{Statistical analysis}

Statistical analysis was performed using GraphPad Prism 7 software. The data are expressed as mean \pm SEM and $n$ refers to the number of animals per experimental group. Statistical tests included one-way ANOVA and two-way ANOVA followed by Newman-Keuls multiple-comparisons tests between groups. Kruskal-Wallis analysis and Mann-Whitney tests were used for neurological deficits. The correlation of infarct volume and neurological deficits was analyzed by Spearman's correlation analysis. Statistical significance was set at $p<0.05$.

\section{Results}

\section{Steroid profiling in brain and plasma of young adult male and female mice}

We first established steroid profiles by GC-MS/MS for brain and plasma of 3-month-old male and female C57BL/6 mice to determine reference values (Fig. 2, Table 3). Females were at their diestrus stage according to vaginal cytology. Results for pregnenolone and progesterone and its major metabolites are shown in Figure 2. Brain levels of pregnenolone were similar in both sexes and $\sim 30$ times higher than in plasma, consistent with a de novo synthesis by neural cells (Fig. $2 A$ ). Levels of progesterone did not differ between sexes in brain, but tended to be higher in the plasma of females. However, in comparison with pregnenolone, brain levels of progesterone were low ( $<1 \mathrm{ng} / \mathrm{g}$; Fig. $2 B$ ). Progesterone is indeed rapidly metabolized in the brain and its measure thus does not provide sufficient information about the dynamics of pregnanes.

The analysis of progesterone metabolites by GC-MS/MS indeed provided a completely different and unexpected picture, with marked differences between brain and plasma and between sexes. In the male brain, levels of $5 \alpha$-DHP were 75 times higher than those of progesterone, reaching concentrations of $12 \mathrm{ng} / \mathrm{g}$ ( $\sim 40 \mathrm{nM}$; Fig. $2 C$ ). Importantly, brain levels of $5 \alpha$-DHP were $\sim 4$ times higher in males than in females and may thus be considered a major male brain steroid. However, plasma levels of $5 \alpha$-DHP were also elevated in males, suggesting an important contribution of the adrenal glands (Fig. 2C).

Consistently, brain levels of the $5 \alpha$-DHP metabolite $3 \alpha, 5 \alpha$ THP were higher in males than in females (Fig. $2 D$ ). Interestingly, brain levels of $3 \alpha, 5 \alpha$-tetrahydrodeoxycorticosterone $(3 \alpha, 5 \alpha$ THDOC), another potent $\mathrm{GABA}_{\mathrm{A}}$ receptor modulator derived from the metabolism of adrenal DOC (Sarkar et al., 2011), were also significantly higher in brain of males compared with females (Table 3).

Therefore, steroid profiling by GC-MS/MS revealed the surprising fact that the male mouse brain contains more neuroactive metabolites of progesterone than the female brain. In contrast, brain and plasma levels of $20 \alpha$-DHP were, respectively, $>10$ or 20 times higher in females compared with males (Fig. $2 E$ ). The reversible conversion of progesterone to $20 \alpha$-DHP may represent a reservoir of brain pregnanes in females. Additional steroids analyzed in brain and plasma of both sexes are shown in Table 3. Compared with the important $5 \alpha$-reduction of progesterone in males, the formation of $5 \alpha$-reduced metabolites of testosterone was very low (Table 3 ).

\section{Steroid profiling after MCAO in brain and plasma of male and female mice}

To gain insight into changes of steroid levels in response to ischemic injury, we performed steroid profiling by GC-MS/MS in the 


\begin{tabular}{|c|c|c|c|c|c|c|c|}
\hline \multirow[b]{2}{*}{ Steroid } & \multirow[b]{2}{*}{ Sex } & \multicolumn{6}{|c|}{ Time post-MCA0 (h) } \\
\hline & & CTL & 1 & 2 & 4 & 6 & 24 \\
\hline \multicolumn{8}{|c|}{ Ipsilateral hemisphere $(\mathrm{ng} / \mathrm{g})$} \\
\hline \multirow[t]{2}{*}{$5 \beta$-DHP } & M & $0.09 \pm 0.08$ & $0.07 \pm 0.01$ & $0.09 \pm 0.03$ & $0.09 \pm 0.04$ & $0.11 \pm 0.04$ & $0.06 \pm 0.01$ \\
\hline & $\mathrm{F}$ & $0.14 \pm 0.08$ & $0.04 \pm 0.02$ & $0.04 \pm 0.01$ & $0.04 \pm 0.02$ & $0.11 \pm 0.03$ & $0.03 \pm 0.01$ \\
\hline \multirow[t]{2}{*}{$3 \beta 5 \alpha-\mathrm{THP}$} & M & $0.36 \pm 0.11$ & $0.44 \pm 0.08$ & $0.41 \pm 0.05$ & $0.33 \pm 0.06$ & $0.43 \pm 0.10$ & $0.61 \pm 0.14$ \\
\hline & $\mathrm{F}$ & $0.09 \pm 0.04$ & $0.01 \pm 0.004$ & $0.09 \pm 0.05$ & $0.07 \pm 0.02$ & $0.09 \pm 0.04$ & $0.14 \pm 0.02^{\$}$ \\
\hline \multirow[t]{2}{*}{$3 \alpha 5 \beta$-ТНP } & M & $0.09 \pm 0.03$ & $0.06 \pm 0.01$ & $0.08 \pm 0.03$ & $0.10 \pm 0.04$ & $0.10 \pm 0.03$ & $0.06 \pm 0.01$ \\
\hline & $\mathrm{F}$ & $0.12 \pm 0.07$ & $0.10 \pm 0.03$ & $0.19 \pm 0.07$ & $0.47 \pm 0.22$ & $0.71 \pm 0.32^{5}$ & $0.47 \pm 0.26$ \\
\hline \multirow[t]{2}{*}{$3 \alpha 5 \alpha 20 \alpha-\mathrm{HHP}$} & M & $0.39 \pm 0.15$ & $0.98 \pm 0.34$ & $0.51 \pm 0.07$ & $0.46 \pm 0.07$ & $0.69 \pm 0.17$ & $0.66 \pm 0.17$ \\
\hline & $\mathrm{F}$ & $0.68 \pm 0.15$ & $0.36 \pm 0.11$ & $0.62 \pm 0.25$ & $0.28 \pm 0.10$ & $0.21 \pm 0.04$ & $0.14 \pm 0.05$ \\
\hline \multirow[t]{2}{*}{$3 \beta 5 \alpha 20 \alpha-H H P$} & M & $0.03 \pm 0.02$ & $0.04 \pm 0.01$ & $0.04 \pm 0.01$ & $0.03 \pm 0.01$ & $0.05 \pm 0.02$ & $0.04 \pm 0.01$ \\
\hline & $\mathrm{F}$ & $0.04 \pm 0.02$ & $0.05 \pm 0.02$ & $0.04 \pm 0.02$ & $0.05 \pm 0.01$ & $0.03 \pm 0.01$ & $0.03 \pm 0.01$ \\
\hline \multirow[t]{2}{*}{$3 \alpha 5 \beta 20 \alpha-H H P$} & M & $0.01 \pm 0.003$ & $0.005 \pm 0.002$ & ND & ND & ND & ND \\
\hline & $\mathrm{F}$ & $0.07 \pm 0.04$ & $0.01 \pm 0.002$ & $0.02 \pm 0.004$ & $0.03 \pm 0.01$ & $0.10 \pm 0.05$ & $0.001 \pm 0.00005$ \\
\hline \multirow[t]{2}{*}{$20 \alpha$-DHPREG } & M & $0.13 \pm 0.02$ & $0.09 \pm 0.03$ & $0.09 \pm 0.01$ & $0.11 \pm 0.01$ & $0.11 \pm 0.01$ & $0.11 \pm 0.02$ \\
\hline & $\mathrm{F}$ & $0.14 \pm 0.03$ & $0.18 \pm 0.03$ & $0.21 \pm 0.08$ & $0.59 \pm 0.50^{\$ \$}$ & $0.21 \pm 0.05$ & $0.11 \pm 0.03$ \\
\hline $\mathrm{DOC}$ & $M$ & $0.02 \pm 0.01$ & $2.68 \pm 0.69$ & $4.56 \pm 0.48^{*}$ & $7.90 \pm 1.56^{* * *}$ & $7.30 \pm 1.57^{* * *}$ & $1.34 \pm 0.40$ \\
\hline & $\mathrm{F}$ & $0.11 \pm 0.03$ & $4.47 \pm 1.49^{* *}$ & $3.27 \pm 0.51$ & $4.79 \pm 0.71^{*}$ & $5.93 \pm 1.41^{* * *}$ & $0.81 \pm 0.27$ \\
\hline $5 \alpha-\mathrm{DHDOC}$ & M & $0.23 \pm 0.04$ & $1.16 \pm 0.25$ & $1.20 \pm 0.18$ & $1.96 \pm 0.30^{*}$ & $1.90 \pm 0.61^{*}$ & $1.48 \pm 0.33$ \\
\hline & $\mathrm{F}$ & $0.06 \pm 0.01$ & $0.49 \pm 0.18$ & $0.75 \pm 0.23^{*}$ & $0.99 \pm 0.26^{* *}$ & $0.90 \pm 0.15^{* *}$ & $0.35 \pm 0.10$ \\
\hline $5 \beta$-DHDOC & M & $0.01 \pm 0.01$ & $0.01 \pm 0.001$ & $0.01 \pm 0.002$ & $0.07 \pm 0.03$ & $0.15 \pm 0.09$ & $0.06 \pm 0.03$ \\
\hline & $\mathrm{F}$ & $0.21 \pm 0.08$ & $2.63 \pm 1.21^{* \$ \$}$ & $3.46 \pm 0.66^{* * \$ \$ \$}$ & $2.43 \pm 0.27^{\$ \$}$ & $3.45 \pm 0.70^{* * \$ \$ \$}$ & $0.95 \pm 0.33$ \\
\hline $3 \alpha 5 \alpha$-THDOC & M & $0.11 \pm 0.03$ & $0.37 \pm 0.01$ & $0.33 \pm 0.07$ & $0.35 \pm 0.06$ & $0.39 \pm 0.14$ & $0.61 \pm 0.19$ \\
\hline & $\mathrm{F}$ & $0.02 \pm 0.01$ & $0.03 \pm 0.01$ & $0.04 \pm 0.01$ & $0.04 \pm 0.01$ & $0.13 \pm 0.02^{* * *}$ & $0.01 \pm 0.002^{\$ \$}$ \\
\hline $3 \alpha 5 \beta$-THDOC & M & $0.01 \pm 0.01$ & $0.03 \pm 0.01$ & $0.003 \pm 0.0003$ & $0.05 \pm 0.02$ & $0.08 \pm 0.05$ & $0.02 \pm 0.01$ \\
\hline & $\mathrm{F}$ & $0.15 \pm 0.06$ & $0.99 \pm 0.84$ & $1.44 \pm 0.78$ & $0.75 \pm 0.41$ & $7.71 \pm 3.36^{* \$ \$ \$}$ & $0.58 \pm 0.54$ \\
\hline Corticosterone & M & $3.76 \pm 1.00$ & $27.6 \pm 6.24$ & $69.0 \pm 21.8$ & $75.7 \pm 23.3$ & $214.6 \pm 41.2^{* * *}$ & $67.0 \pm 23.5$ \\
\hline & $\mathrm{F}$ & $1.40 \pm 0.33$ & $17.0 \pm 6.85$ & $49.2 \pm 13.6^{* *}$ & $76.1 \pm 20.2^{* * *}$ & $68.6 \pm 10.6^{* * * \$ \$ \$}$ & $20.4 \pm 8.61$ \\
\hline Testosterone & M & $1.21 \pm 0.39$ & $0.22 \pm 0.06^{* * *}$ & $0.15 \pm 0.05^{* * *}$ & $0.14 \pm 0.03^{* * *}$ & $0.08 \pm 0.01^{* * *}$ & $0.06 \pm 0.01^{* * *}$ \\
\hline & $\mathrm{F}$ & $0.02 \pm 0.01^{\$ \$ \$}$ & $0.04 \pm 0.02$ & $0.01 \pm 0.01$ & $0.03 \pm 0.03$ & $0.02 \pm 0.005$ & $0.01 \pm 0.01$ \\
\hline $5 \alpha-\mathrm{DHT}$ & $M$ & $0.19 \pm 0.06$ & $0.06 \pm 0.02^{* * *}$ & $0.02 \pm 0.01^{* * *}$ & $0.03 \pm 0.01^{* * *}$ & $0.02 \pm 0.01^{* * *}$ & $0.02 \pm 0.001^{* * * *}$ \\
\hline & $\mathrm{F}$ & $0.02 \pm 0.01^{\$ \$ \$}$ & $0.02 \pm 0.01$ & $0.02 \pm 0.01$ & $0.002 \pm 0.001$ & $0.01 \pm 0.004$ & $0.002 \pm 0.001$ \\
\hline $3 \alpha 5 \alpha$-ТНТ & M & $0.16 \pm 0.05$ & $0.05 \pm 0.01^{* * *}$ & $0.02 \pm 0.02^{* * *}$ & ND & $0.003 \pm 0.002^{* * *}$ & $0.01 \pm 0.01^{* * *}$ \\
\hline & $\mathrm{F}$ & ND & ND & ND & ND & ND & ND \\
\hline Estradiol & M & $0.04 \pm 0.01$ & $0.05 \pm 0.02$ & $0.04 \pm 0.02$ & $0.06 \pm 0.01$ & $0.04 \pm 0.02$ & $0.02 \pm 0.01$ \\
\hline & $F$ & $0.02 \pm 0.01$ & $0.01 \pm 0.002$ & $0.02 \pm 0.01$ & $0.01 \pm 0.01$ & $0.001 \pm 0.0002$ & $0.02 \pm 0.01$ \\
\hline Plasma (ng/ml) & & & & & & & \\
\hline $5 \beta$-DHP & M & $0.02 \pm 0.01$ & ND & ND & ND & ND & ND \\
\hline & $\mathrm{F}$ & $0.02 \pm 0.01$ & $0.12 \pm 0.01^{* * * \$ \$ \$}$ & $0.12 \pm 0.01^{* * * \$ \$ \$}$ & $0.11 \pm 0.02^{* * * \$ \$ \$}$ & $0.17 \pm 0.03^{* * * \$ \$ \$}$ & $0.09 \pm 0.02^{* * \$ \$ \$}$ \\
\hline $3 \beta 5 \alpha$-ТНP & M & $0.01 \pm 0.003$ & $0.03 \pm 0.01$ & $0.05 \pm 0.02$ & $0.04 \pm 0.01$ & $0.07 \pm 0.02$ & $0.04 \pm 0.02$ \\
\hline & $\mathrm{F}$ & $0.02 \pm 0.004$ & $0.01 \pm 0.002$ & $0.02 \pm 0.002$ & $0.01 \pm 0.005$ & $0.02 \pm 0.01$ & $0.02 \pm 0.01$ \\
\hline $3 \alpha 5 \beta$-ТНР & M & $0.07 \pm 0.02$ & $0.10 \pm 0.03$ & $0.07 \pm 0.02$ & $0.06 \pm 0.01$ & $0.10 \pm 0.02$ & $0.09 \pm 0.04$ \\
\hline & $\mathrm{F}$ & $0.33 \pm 0.07$ & $0.22 \pm 0.09$ & $0.57 \pm 0.06$ & $0.74 \pm 0.09^{\$ \$}$ & $1.03 \pm 0.38^{* \$ \$ \$}$ & $0.25 \pm 0.09$ \\
\hline $3 \alpha 5 \alpha 20 \alpha-\mathrm{HHP}$ & M & $0.18 \pm 0.10$ & $0.14 \pm 0.05$ & $0.35 \pm 0.05$ & $0.54 \pm 0.11$ & $0.52 \pm 0.12$ & $0.34 \pm 0.07$ \\
\hline & $\mathrm{F}$ & $0.32 \pm 0.07$ & $0.26 \pm 0.03$ & $0.54 \pm 0.11$ & $0.35 \pm 0.03$ & $0.27 \pm 0.07$ & $0.22 \pm 0.04$ \\
\hline $3 \beta 5 \alpha 20 \alpha-\mathrm{HHP}$ & M & $0.01 \pm 0.003$ & $0.02 \pm 0.004$ & $0.04 \pm 0.02$ & $0.05 \pm 0.02$ & $0.05 \pm 0.02$ & $0.06 \pm 0.01$ \\
\hline & $\mathrm{F}$ & $0.04 \pm 0.01$ & $0.05 \pm 0.01$ & $0.10 \pm 0.03$ & $0.04 \pm 0.01$ & $0.03 \pm 0.01$ & $0.03 \pm 0.01$ \\
\hline $3 \alpha 5 \beta 20 \alpha$-HHP & M & $0.03 \pm 0.02$ & $0.01 \pm 0.003$ & $0.004 \pm 0.002$ & $0.02 \pm 0.01$ & $0.01 \pm 0.005$ & $0.01 \pm 0.004$ \\
\hline & $\mathrm{F}$ & $0.06 \pm 0.02$ & $0.07 \pm 0.02$ & $0.15 \pm 0.04^{\$ \$}$ & $0.23 \pm 0.02^{* * \$ \$ \$}$ & $0.25 \pm 0.06^{* * \$ \$ \$}$ & $0.07 \pm 0.02$ \\
\hline $20 \alpha$-DHPREG & M & $0.01 \pm 0.005$ & $0.03 \pm 0.01$ & $0.02 \pm 0.01$ & $0.03 \pm 0.002$ & $0.02 \pm 0.004$ & $0.02 \pm 0.01$ \\
\hline & $\mathrm{F}$ & $0.02 \pm 0.01$ & $0.01 \pm 0.01$ & $0.01 \pm 0.01$ & $0.03 \pm 0.002$ & $0.02 \pm 0.01$ & $0.02 \pm 0.01$ \\
\hline DOC & M & $0.28 \pm 0.13$ & $1.42 \pm 0.36$ & $2.27 \pm 0.68$ & $2.78 \pm 0.63$ & $4.83 \pm 1.04^{* * *}$ & $0.84 \pm 0.47$ \\
\hline & $\mathrm{F}$ & $0.20 \pm 0.07$ & $1.31 \pm 0.45$ & $2.07 \pm 0.52$ & $4.08 \pm 0.93^{* * *}$ & $3.26 \pm 0.66^{* * *}$ & $0.81 \pm 0.27$ \\
\hline $5 \alpha-\mathrm{DHDOC}$ & M & $0.20 \pm 0.06$ & $0.35 \pm 0.09$ & $0.34 \pm 0.15$ & $0.50 \pm 0.14$ & $0.39 \pm 0.16$ & $0.43 \pm 0.13$ \\
\hline & $\mathrm{F}$ & $0.09 \pm 0.03$ & $0.04 \pm 0.02$ & $0.05 \pm 0.02$ & $0.18 \pm 0.02$ & $0.18 \pm 0.06$ & $0.08 \pm 0.02$ \\
\hline $5 \beta$-DHDOC & M & $0.02 \pm 0.0002$ & $0.03 \pm 0.01$ & $0.02 \pm 0.003$ & $0.03 \pm 0.02$ & $0.01 \pm 0.002$ & $0.06 \pm 0.03$ \\
\hline & $\mathrm{F}$ & $0.21 \pm 0.07$ & $1.64 \pm 0.21^{* * \$ \$ \$}$ & $1.79 \pm 0.19^{* * \$ \$ \$}$ & $2.89 \pm 0.17^{* * * \$ \$ \$}$ & $2.54 \pm 0.47^{* * * \$ \$ \$ \$}$ & $1.01 \pm 0.39^{* \$ \$ \$}$ \\
\hline $3 \alpha 5 \alpha$-THDOC & M & $0.11 \pm 0.05$ & $0.26 \pm 0.09$ & $0.39 \pm 0.22$ & $0.51 \pm 0.23$ & $0.38 \pm 0.20$ & $0.41 \pm 0.19$ \\
\hline & $F$ & $0.02 \pm 0.01$ & $0.05 \pm 0.01$ & $0.09 \pm 0.03$ & $0.24 \pm 0.07^{* * *}$ & $0.17 \pm 0.03^{*}$ & $0.05 \pm 0.01$ \\
\hline $3 \alpha 5 \beta$-THDOC & $M$ & $0.01 \pm 0.01$ & $0.04 \pm 0.01$ & $0.07 \pm 0.06$ & $0.10 \pm 0.03$ & $0.03 \pm 0.01$ & $0.05 \pm 0.03$ \\
\hline & $F$ & $0.39 \pm 0.17$ & $6.95 \pm 1.43$ & $13.9 \pm 0.94^{* \$ \$}$ & $29.6 \pm 3.11^{* * * \$ \$ \$}$ & $21.8 \pm 7.52^{* * * \$ \$ \$}$ & $4.58 \pm 2.10$ \\
\hline Corticosterone & M & $10.2 \pm 4.71$ & $109.2 \pm 13.9^{* *}$ & $139.3 \pm 21.9^{* * *}$ & $215.6 \pm 33.6^{* * *}$ & $213.2 \pm 12.2^{* * *}$ & $67.6 \pm 18.1^{*}$ \\
\hline & $\mathrm{F}$ & $21.5 \pm 5.99$ & $60.5 \pm 6.80$ & $92.0 \pm 4.13$ & $182.4 \pm 41.3^{* *}$ & $191.2 \pm 42.2^{* *}$ & $66.4 \pm 31.6$ \\
\hline Testosterone & M & $2.16 \pm 0.87$ & $0.34 \pm 0.07^{* * *}$ & $0.15 \pm 0.04^{* * *}$ & $0.14 \pm 0.02^{* * *}$ & $0.11 \pm 0.02^{* * *}$ & $0.05 \pm 0.01^{* * *}$ \\
\hline & $\mathrm{F}$ & $0.01 \pm 0.003^{\$ \$ \$}$ & $0.02 \pm 0.01$ & $0.01 \pm 0.01$ & $0.03 \pm 0.01$ & $0.02 \pm 0.01$ & $0.02 \pm 0.003$ \\
\hline $5 \alpha-\mathrm{DHT}$ & M & $0.08 \pm 0.02$ & $0.02 \pm 0.01$ & $0.04 \pm 0.03$ & $0.06 \pm 0.03$ & $0.06 \pm 0.03$ & $0.08 \pm 0.04$ \\
\hline & $\mathrm{F}$ & $0.01 \pm 0.002$ & ND & $0.02 \pm 0.01$ & $0.004 \pm 0.002$ & $0.01 \pm 0.004$ & $\begin{array}{l}0.004 \pm 0.003 \\
\quad \text { (Table continues) }\end{array}$ \\
\hline
\end{tabular}


Table 4. Continued

\begin{tabular}{|c|c|c|c|c|c|c|c|}
\hline \multirow[b]{2}{*}{ Steroid } & \multirow[b]{2}{*}{ Sex } & \multicolumn{6}{|c|}{ Time post-MCA0 (h) } \\
\hline & & CTL & 1 & 2 & 4 & 6 & 24 \\
\hline \multirow[t]{2}{*}{$3 \alpha 5 \alpha$-ТНТ } & $M$ & $0.25 \pm 0.06$ & $0.17 \pm 0.07$ & $0.06 \pm 0.02^{*}$ & $0.05 \pm 0.003^{*}$ & $0.03 \pm 0.01^{* *}$ & ND \\
\hline & $\mathrm{F}$ & ND & ND & ND & ND & ND & ND \\
\hline \multirow[t]{2}{*}{ Estradiol } & M & $0.02 \pm 0.01$ & $0.02 \pm 0.003$ & $0.03 \pm 0.002$ & $0.04 \pm 0.01$ & $0.03 \pm 0.01$ & $0.03 \pm 0.01$ \\
\hline & $\mathrm{F}$ & $0.03 \pm 0.01$ & $0.08 \pm 0.03$ & $0.02 \pm 0.01$ & $0.06 \pm 0.02$ & $0.01 \pm 0.01$ & $0.04 \pm 0.02$ \\
\hline
\end{tabular}

Plasma and brain levels of steroids are expressed as $\mathrm{ng} / \mathrm{ml}$ for plasma or $\mathrm{ng} / \mathrm{g}$ for brain (mean $\pm \mathrm{SEM} ; n=4-10$ per group). Statistical analysis: one way ANOVA followed by Newman-Keuls multiple-comparisons tests. ${ }^{* * *} p<0.001,{ }^{* *} p<0.01,{ }^{*} p<0.05$ versus CTL (controls) without MCAO and by two-way ANOVA (sex $\times$ time) followed by Newman-Keuls multiple-comparisons tests. Significance: ${ }^{\$ \$ \$} p<0.001,{ }^{\$ \$} p<0.01, \$ p<0.05$ females versus males.

Abbreviations of steroids are as for Table 1. ND, Not detected.

Males

\section{A}

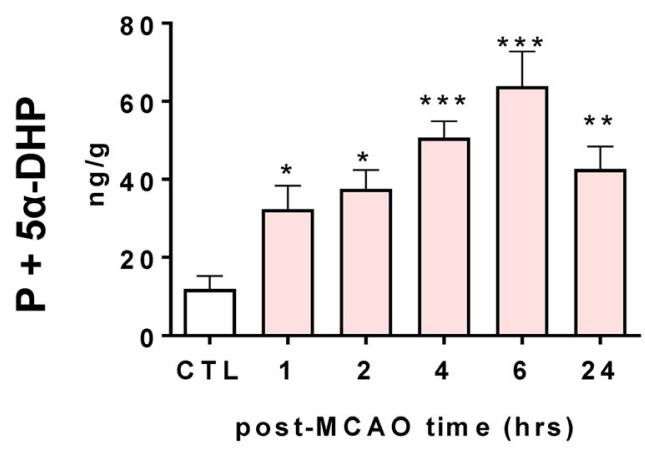

B

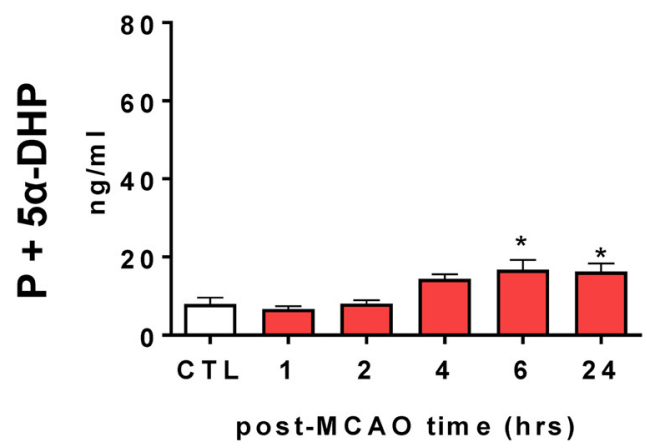

Females

C Ipsilateral hemisphere

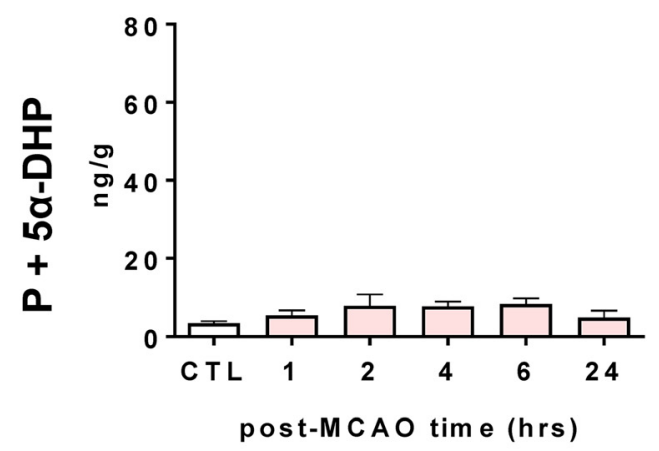

Plasma

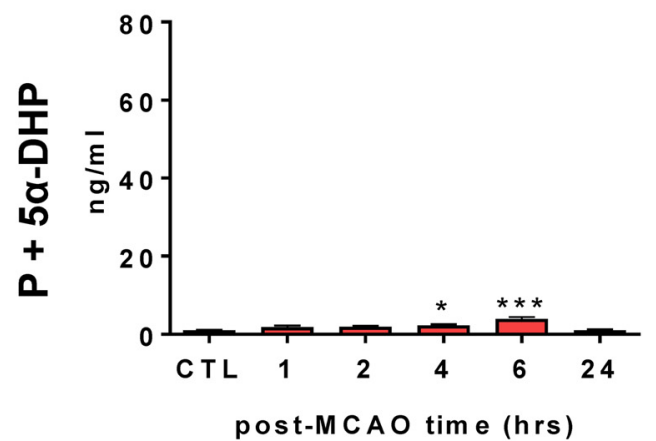

Figure 4. Rapid and marked increase in the summed levels of the PR-active steroids progesterone and $5 \alpha$-DHP after MCAO in the ipsilateral hemisphere of males. $\boldsymbol{A}$, In the male brain, progesterone $+5 \alpha$-DHP increased progressively between 1 and $6 \mathrm{~h}$ after MCA0 and remained elevated at $24 \mathrm{~h}\left(F_{(5,45)}=7.87, p<0.0001\right) . \boldsymbol{B}$, In the plasma of males, pooled levels of progesterone $+5 \alpha$-DHP remained low, but showed a small increase over time $\left(F_{(5,37)}=6.48, p<0.001\right)$. C, In contrast to males, levels of progesterone $+5 \alpha$-DHP remained very low in the female brain and were not affected by MCA0. D, There was a slight, albeit significant increase in female plasma levels of progesterone $+5 \alpha$-DHP at 4 and $6 \mathrm{~h}\left(F_{(5,28)}=13.1, p<0.0001\right)$.

left ischemic hemisphere and in plasma of male and diestrus female C57BL/ 6 mice at 1, 2, 4, 6, or $24 \mathrm{~h}$ after transient MCAO. The left middle cerebral artery was occluded for $30 \mathrm{~min}$, followed by reperfusion (Fig. 3, Table 4).

In both males and females, brain levels of pregnenolone were $\sim 5-10$ times higher in brain compared with plasma, confirming results of the previous experiment (Fig. $3 A$ ). In the ipsilateral hemisphere, levels of pregnenolone were increased significantly at $6 \mathrm{~h}$ after MCAO and returned to control values after $24 \mathrm{~h}$ in males. There was no such change with time in females. In both sexes, the low plasma levels of pregnenolone were slightly, but significantly, increased in a transient manner at 4 and $6 \mathrm{~h}$ (Fig. $3 A$ ).

In males, brain levels of progesterone were increased at 4 and $6 \mathrm{~h}$ after MCAO, paralleled by a similar increase in plasma levels, which probably reflects activation of the adrenal glands (Fig. 3B). A similar trend was observed in females, but without reaching statistical significance for the brain. At $6 \mathrm{~h}$, brain and plasma levels of progesterone were lower in females compared with males.

The magnitude of brain-specific changes in endogenous progesterone after MCAO may have been partially masked by its rapid and strong $5 \alpha$-reduction (Poletti et al., 1998). Indeed, the most marked differences between tissues and sexes were observed for $5 \alpha$-DHP. In the male ipsilateral hemisphere, levels of $5 \alpha$ DHP raised continuously between 1 and $6 \mathrm{~h}$ after MCAO (Fig. $3 C$ ). Maximal and very elevated brain levels of $5 \alpha$-DHP were reached at $6 \mathrm{~h}$. In plasma, levels of $5 \alpha$-DHP remained much lower, with a slight increase at $24 \mathrm{~h}$. Levels of $5 \alpha$-DHP remained 


\section{A Males}
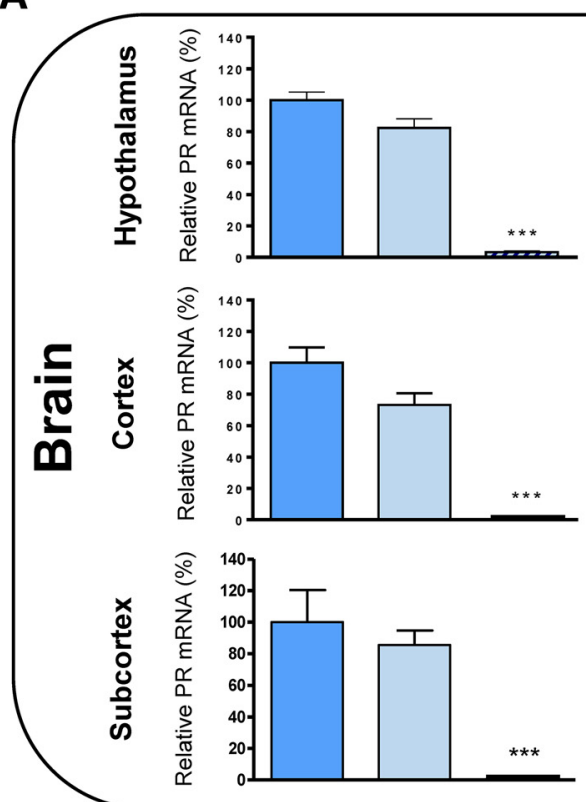

Females
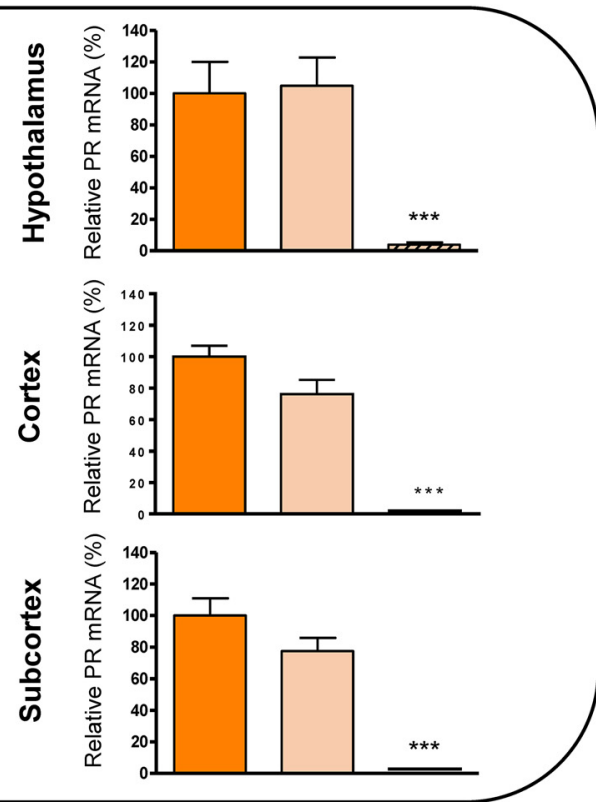

B

c

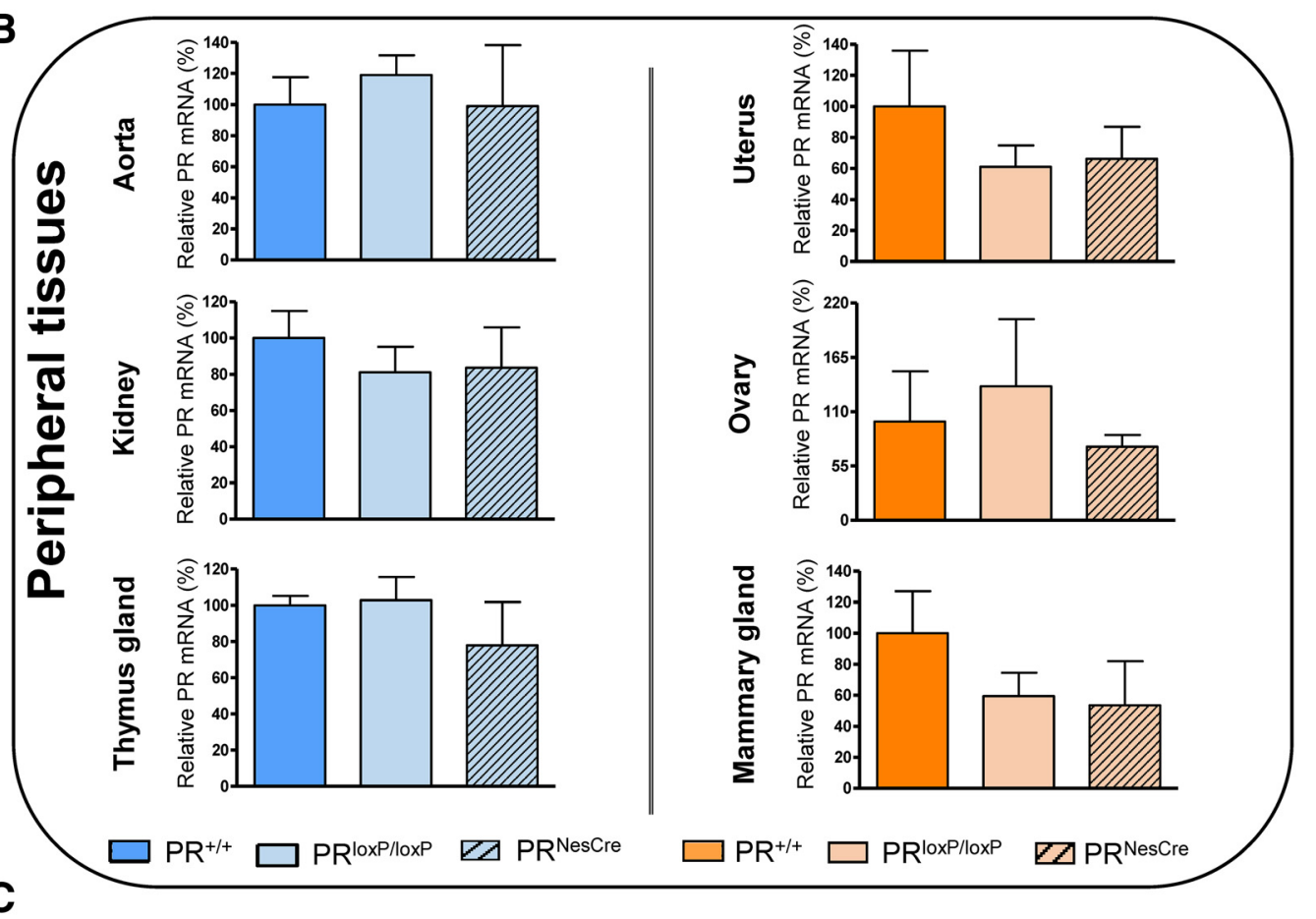

Hypothalamus

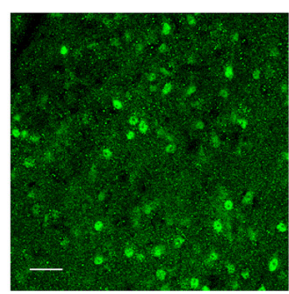

PR ${ }^{\text {loxPlloxP }}$

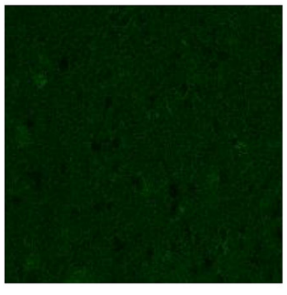

PR $^{\text {NesCre }}$

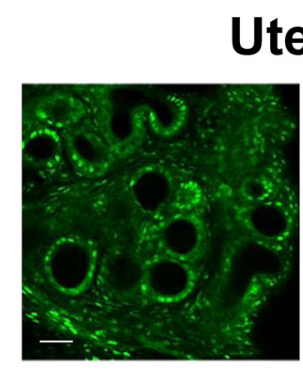

PR ${ }^{\text {loxP/loxP }}$

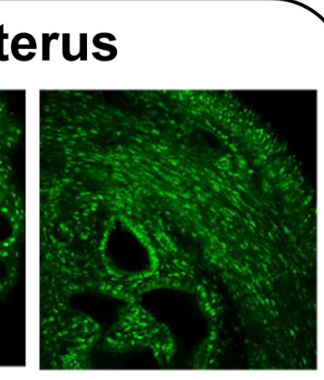

PR ${ }^{\text {NesCre }}$

Figure 5. Verification of the selective deletion of the progesterone receptors in the brain of $P R{ }^{\text {Nescre }}$ mice. $\boldsymbol{A}, \boldsymbol{B}, \mathrm{PR} m \mathrm{mRNA}$ expression was analyzed by $q-P C R$ ( $n=4$ per group). $\boldsymbol{A}$, In hypothalamus, cerebral cortex, and subcortical regions, PR mRNA expression was similar in wild-type (PR ${ }^{+/+}$) and male and female $P R^{\text {loxP/loxP }}$ mice, but was almost completely abolished in $P R^{\text {Nescre }}$ mice. $\boldsymbol{B}$, In contrast to the brain, PR mRNA expression was not affected in peripheral tissues of PR ${ }^{\text {Nescre }}$ mice, including aorta, kidney, and thymus for males and uterus, (Figure legend continues.) 
elevated in the male brain as late as $24 \mathrm{~h}$ after MCAO. In contrast, levels of $5 \alpha$-DHP remained low in brain $(\leq 5 \mathrm{ng} / \mathrm{g}$ ) and plasma $(\leq 1 \mathrm{ng} / \mathrm{ml}$ ) of females (Fig. $3 C$ ).

The $\mathrm{GABA}_{\mathrm{A}}$ receptor active progesterone metabolite $3 \alpha, 5 \alpha$ THP did not show significant changes with time after MCAO in both sexes either in brain or in plasma. However, levels of $3 \alpha, 5 \alpha-$ THP in brain and plasma were higher in males compared with females (Fig. 3D). In males, levels of $20 \alpha$-DHP were increased significantly in brain and plasma at 4 and $6 \mathrm{~h}$ after MCAO. No significant changes over time for the constantly elevated levels of $20 \alpha$-DHP in females (Fig. 3E).

Summing the levels of progesterone and $5 \alpha$-DHP well illustrates the rapid and marked increase in PR-active steroids in male brain after MCAO and the noticeable sex difference. Both pregnanes reached maximal levels of nearly $70 \mathrm{ng} / \mathrm{g}(\sim 220 \mathrm{nM})$ at $6 \mathrm{~h}$ after MCAO in the male brain (Fig. $4 A$ ), which is comparable to their pregnancy plasma levels in mice (Murr et al., 1974). In males, plasma levels of progesterone $+5 \alpha$-DHP were $\sim 6$ times lower than brain levels, and only showed a small increase at 6 and $24 \mathrm{~h}$ (Fig. 4B). In contrast to males, summed levels of progesterone $+5 \alpha$-DHP remained low after MCAO in the female brain and plasma (Fig. 4C,D).

Additional steroid metabolomic data for brain and plasma, providing reference data, are presented in Table 4 . In contrast to $5 \alpha$-DHP, levels of $5 \beta$-DHP were very low in brain and plasma of both sexes $(\sim 10$ pg per g or $\mathrm{ml})$. Because the molecular structure of $5 \beta$-reduced steroids is not planar but bent, they are considered as biologically inactive and to be involved in hormone clearance (Chen and Penning, 2014). However, some $5 \beta$-reduced metabolites of progesterone have neuroactive properties. Therefore, $3 \alpha, 5 \beta$-tetrahydroprogesterone $(3 \alpha, 5 \beta$-THP, pregnanolone) is like $3 \alpha, 5 \alpha$-THP (allopregnanolone) a positive allosteric modulator of $\mathrm{GABA}_{\mathrm{A}}$ receptors, both having the same potency (Belelli et al., 1996). Interestingly, whereas brain and plasma levels of $3 \alpha, 5 \alpha$-THP were higher in males (Fig. $3 D$ ), those of $3 \alpha, 5 \beta$-THP were higher in females at $6 \mathrm{~h}$ after MCAO (Table 4). Levels of $3 \alpha, 5 \beta, 20 \alpha$-hexahydroprogesterone were also higher in females than in males, but the biological significance of the hexahydroprogesterone isomers remains to be explored.

Remarkable were sex differences in the levels of neuroactive steroids derived from the adrenal glands. Plasma levels of corticosterone, the principal glucocorticoid in mice and rats, increased from 10 to $20 \mathrm{ng} / \mathrm{ml}$ in controls to $\sim 200 \mathrm{ng} / \mathrm{mg}$ at $6 \mathrm{~h}$ after MCAO in both sexes (effect of time: $F_{(5,47)}=18.3, p<$ 0.0001; Table 4). However, in the brain, a different picture was observed. Although levels of corticosterone increased significantly in the ischemic hemisphere of both sexes (effect of time: $\left.F_{(5,76)}=13.2, p<0.0001\right)$, they remained lower than in plasma until $4 \mathrm{~h}$ after MCAO. Only at $6 \mathrm{~h}$ did brain levels of corticosterone reach plasma levels in males, whereas in females, brain levels of corticosterone remained lower (effect of sex: $F_{(1,76)}=10.5, p=$ 0.002 ; interaction between time and $\operatorname{sex}\left(F_{(5,76)}=4.31, p=\right.$ $0.002)$. The female brain may thus protect itself against the steadily increasing, very high levels of adrenal glucocorticoids.

\section{$\leftarrow$}

(Figure legend continued.) ovaries, and mammary glands for females. Results are presented as means \pm SEM. Group differences were analyzed by one-way ANOVA followed by NewmanKeuls multiple-comparisons tests. ${ }^{* * *} p<0.001$ compared with PR ${ }^{\text {loxP/loxP }}$ mice. C, Successful deletion of PR was also verified in the hypothalamus at the protein level by immunofluorescence. No specific immunostaining was detected in PR ${ }^{\text {Nescre }}$ mice. In contrast to the hypothalamus, PR immunostaining was not decreased in the uterus of $P R^{\text {Nescre }}$ mice compared with $P R^{\text {loxP/loxP }}$ mice. Scale bar, $50 \mu \mathrm{m}$.
After $24 \mathrm{~h}$, levels of the adrenal steroids returned to lower levels but remained above control levels.

In the plasma, conversion of the corticosterone precursor DOC to its $5 \beta$-reduced metabolites $5 \beta$-DHDOC (effect of sex: $F_{(1,59)}=244.7, p<0.0001$ ) and $3 \alpha, 5 \beta$-THDOC (effect of sex: $\left.F_{(1,50)}=80.7, p<0.0001\right)$ was much higher in females than in males (Table 4 ). In the circulation, the sum of both $5 \beta$-reduced metabolites reached $32 \mathrm{ng} / \mathrm{ml}$ in females at $4 \mathrm{~h}$, which were $\sim 250$ times the levels measured in males. In the brain, levels of both metabolites were also higher in females than in males ( $5 \beta$-DHDOC: effect of sex: $F_{(1,77)}=83.5, p<0.0001 ; 3 \alpha, 5 \beta$-THDOC: effect of sex: $F_{(1,67)}=6.69, p<0.05$; Table 4$)$. Therefore, females produce significantly higher amounts of $\mathrm{GABA}_{\mathrm{A}}$ receptor active $5 \beta$-reduced metabolites of progesterone and DOC, respectively, $3 \alpha, 5 \beta$-THP, and, by structural analogy, $3 \alpha, 5 \beta$-THDOC (Gunn et al., 2015).

In contrast to the glucocorticoids, levels of testosterone decreased after the ischemic injury in plasma (effect of time: $F_{(5,59)}=5.38, p<$ 0.001 ) and brain (effect of time: $F_{(5,73)}=5.89, p<0.001$ ) of males (Table 4). Moreover, there was a significant decrease in male brain $5 \alpha$-DHT levels (effect of time: $F_{(5,67)}=5.41, p<0.001$ ). This decrease in the $5 \alpha$-reduction of testosterone thus differs from the marked increase in the formation of $5 \alpha$-reduced metabolites of progesterone in males (Fig. 3C,D). As expected (Nilsson et al., 2015), low brain concentrations of estradiol were measured and no significant changes over time were observed after MCAO.

\section{Selective deletion of intracellular PRs in the CNS}

We hypothesized that the rapid and important increase in brain levels of progesterone and $5 \alpha$-DHP may be part of spontaneous cerebroprotective responses. To gain an insight into the potential role of these endogenous PR ligands in the acute resistance of brain tissues against ischemic damage, we inactivated PR expression selectively in neural cells using the Cre-LoxP site-specific recombination system to generate a new transgenic mice line $\mathrm{PR}^{\mathrm{Nes} C r e}$

Specificity and efficiency of neural PR gene invalidation via Cre recombination were determined by quantitative RT-PCR (qPCR) and immunofluorescence analyses. qPCR showed a nearly complete deletion of PR mRNA expression in the brain of $\mathrm{PR}^{\text {NesCre }}$ males and females (96\% in hypothalamus and $99 \%$ in cortex and subcortical regions; Fig. 5A). In contrast to the brain, $\mathrm{PR}$ mRNA expression was similar in wild-type $\mathrm{PR}^{+/+}, \mathrm{PR}^{\text {loxP/loxP }}$, and $\mathrm{PR}^{\text {NesCre }}$ mice for aorta, kidney, and thymus in males and for uterus, ovaries, and mammary glands in females (Fig. 5B). Immunofluorescence detection revealed that neural PR protein was expressed in the hypothalamus of $\mathrm{PR}^{\text {loxP/loxP }}$ mice, but was almost completely absent in the hypothalamus of $\mathrm{PR}^{\mathrm{Nes} C r e}$ mice (Fig. 5C). In contrast to the hypothalamus, a similar distribution and density of PR immunoreactivity was observed in the uterus of $\mathrm{PR}^{\text {loxP/loxP }}$ and $\mathrm{PR}{ }^{\text {NesCre }}$ female mice (Fig. 5C). Altogether, these results demonstrate that the $\mathrm{PR}$ gene was invalidated efficiently and selectively in the brains of both male and female $\mathrm{PR}^{\mathrm{Nes} C r e}$ mice. Because the Cre recombinase was not expressed in microglia, present results also show that, in the mouse brain, PRs are not present in this cell type.

At the age of 1 month, $\mathrm{PR}^{\text {NesCre }}$ mice had the same weight as sex-matched $P R^{\text {loxP/loxP }}$ mice. At 4 months, about the time when experiments of ischemic injury in young animals were performed, $\mathrm{PR}^{\text {NesCre }}$ mice were $6-7 \%$ lighter than $\mathrm{PR}^{\text {loxP/loxP }}$ mice of the same sex (males: $\mathrm{PR}^{\text {NesCre }}: 26.4 \pm 0.2 \mathrm{~g} ; \mathrm{PR}^{\text {loxP/loxP }}: 28.1 \pm$ 0.2 g; females: $\mathrm{PR}^{\text {NesCre }}: 20.9 \pm 0.2 \mathrm{~g} ; \mathrm{PR}^{\text {loxP/loxP }}: 22.4 \pm 0.2 \mathrm{~g}$, means \pm SEM; effect of sex: $F_{(1,29)}=1208.1, p<0.001$; effect of genotype: $\left.F_{(1,29)}=100.3, p<0.001\right)$. At 12 months, the weight 
Table 5. Steroid profiling in brain (left hemisphere) and plasma of young adult PR ${ }^{\text {loxP/loxP }}$ and $P R^{\text {Nescre }}$ mice of both sexes

\begin{tabular}{|c|c|c|c|c|c|}
\hline \multirow[b]{2}{*}{ Steroid } & \multicolumn{2}{|l|}{$P R^{10 x P / / 0 x P}$} & \multicolumn{2}{|l|}{$P R^{\text {NesCre }}$} & \multirow[b]{2}{*}{ Two-way ANOVA } \\
\hline & Males & Females & Males & Females & \\
\hline \multicolumn{6}{|c|}{ Left hemisphere (ng/g) } \\
\hline Pregnenolone & $9.94 \pm 0.61$ & $6.84 \pm 0.08^{*}$ & $10.3 \pm 0.78$ & $6.14 \pm 0.17^{*}$ & $\begin{array}{l}\text { Sex: } F_{(1,17)}=20.4 ; p=0.0003 \\
\text { Genotype: } F_{(1,17)}=0.05 ; p=0.825 \\
\text { Interaction: } F_{(1,17)}=0.43 ; p=0.521\end{array}$ \\
\hline Progesterone & $0.73 \pm 0.08$ & $0.44 \pm 0.06$ & $0.38 \pm 0.14$ & $0.46 \pm 0.11$ & $\begin{array}{l}\text { Sex: } F_{(1,17)}=1.09 ; p=0.311 \\
\text { Genotype: } F_{(1,17)}=2.59 ; p=0.126 \\
\text { Interaction: } F_{(1,17)}=3.10 ; p=0.096\end{array}$ \\
\hline $5 \alpha-\mathrm{DHP}$ & $24.0 \pm 5.36$ & $5.69 \pm 0.95^{* *}$ & $28.3 \pm 2.52$ & $4.81 \pm 0.32^{* *}$ & $\begin{array}{l}\text { Sex: } F_{(1,18)}=29.2 ; p<0.0001 \\
\text { Genotype: } F_{(1,18)}=0.19 ; p=0.669 \\
\text { Interaction: } F_{(1,18)}=0.44 ; p=0.515\end{array}$ \\
\hline $3 \alpha, 5 \alpha-$ ТHP & $3.57 \pm 0.79$ & $0.53 \pm 0.18^{* * *}$ & $1.46 \pm 0.20^{\$ \$}$ & $0.15 \pm 0.03$ & $\begin{array}{l}\text { Sex: } F_{(1,18)}=31.6 ; p<0.0001 \\
\text { Genotype: } F_{(1,18)}=10.3 ; p=0.005 \\
\text { Interaction: } F_{(1,18)}=4.96 ; p=0.039\end{array}$ \\
\hline $20 \alpha-\mathrm{DHP}$ & $2.12 \pm 0.16$ & $22.6 \pm 6.42^{* *}$ & $0.90 \pm 0.28$ & $18.5 \pm 1.63^{*}$ & $\begin{array}{l}\text { Sex: } F_{(1,16)}=21.9 ; p=0.0003 \\
\text { Genotype: } F_{(1,16)}=0.43 ; p=0.522 \\
\text { Interaction: } F_{(116)}=0.13 ; p=0.728\end{array}$ \\
\hline $5 \alpha, 20 \alpha$-ТHP & $1.30 \pm 0.20$ & $0.64 \pm 0.16^{* *}$ & $0.50 \pm 0.07^{\$ \$}$ & $0.61 \pm 0.05$ & $\begin{array}{l}\text { Sex: } F_{(1,17)}=3.60 ; p=0.075 \\
\text { Genotype: } F_{(1,17)}=8.38 ; p=0.010 \\
\text { Interaction: } F_{(1,17)}=7.28 ; p=0.015\end{array}$ \\
\hline $5 \beta$-DHP & ND & $0.28 \pm 0.04$ & ND & $0.30 \pm 0.06$ & \\
\hline $3 \beta 5 \alpha-$ THP & $0.44 \pm 0.10$ & $0.01 \pm 0.004^{* * *}$ & $0.12 \pm 0.02^{\$ \$ \$}$ & $0.01 \pm 0.002$ & $\begin{array}{l}\text { Sex: } F_{(1,17)}=27.4 ; p<0.0001 \\
\text { Genotype: } F_{(1,17)}=9.49 ; p=0.007 \\
\text { Interaction: } F_{(1,17)}=9.27 ; p=0.007\end{array}$ \\
\hline $3 \alpha 5 \beta$-ТHP & $0.03 \pm 0.01$ & $0.24 \pm 0.05^{* *}$ & $0.10 \pm 0.02$ & $0.34 \pm 0.06^{* * *}$ & $\begin{array}{l}\text { Sex: } F_{(1,17)}=32.3 ; p<0.0001 \\
\text { Genotype: } F_{(1,17)}=4.55 ; p=0.048 \\
\text { Interaction: } F_{(1,17)}=0.30 ; p=0.592\end{array}$ \\
\hline $3 \alpha 5 \alpha 20 \alpha-\mathrm{HHP}$ & $1.29 \pm 0.37$ & $0.53 \pm 0.10^{*}$ & $0.35 \pm 0.05^{5}$ & $0.58 \pm 0.04$ & $\begin{array}{l}\text { Sex: } F_{(1,15)}=1.69 ; p=0.213 \\
\text { Genotype: } F_{(1,15)}=4.61 ; p=0.049 \\
\text { Interaction: } F_{(1,1)}=5.82 ; p=0.029\end{array}$ \\
\hline $3 \beta 5 \alpha 20 \alpha-\mathrm{HHP}$ & $0.18 \pm 0.05$ & $0.04 \pm 0.01^{* *}$ & $0.04 \pm 0.01^{\$ \$}$ & $0.03 \pm 0.001$ & $\begin{array}{l}\text { Sex: } F_{(1,15)}=8.63 ; p=0.010 \\
\text { Genotype: } F_{(1,15)}=7.17 ; p=0.017 \\
\text { Interaction: } F_{(1,15)}=5.07 ; p=0.040\end{array}$ \\
\hline $3 \alpha 5 \beta 20 \alpha-H H P$ & $0.01 \pm 0.003$ & $0.07 \pm 0.03^{*}$ & ND & $0.27 \pm 0.01 * * * \$ \$$ & \\
\hline $20 \alpha$-DHPREG & $0.41 \pm 0.02$ & $0.30 \pm 0.02^{*}$ & $0.35 \pm 0.04$ & $0.34 \pm 0.01$ & $\begin{array}{l}\text { Sex: } F_{(1,17)}=5.47 ; p=0.032 \\
\text { Genotype: } F_{(1,17)}=0.25 ; p=0.625 \\
\text { Interaction: } F_{(1,17)}=4.16 ; p=0.057\end{array}$ \\
\hline $\mathrm{DOC}$ & $1.78 \pm 0.31$ & $7.25 \pm 1.32^{* * *}$ & $1.11 \pm 0.45$ & $6.02 \pm 0.31^{* *}$ & $\begin{array}{l}\text { Sex: } F_{(1,17)}=38.1 ; p<0.0001 \\
\text { Genotype: } F_{(1,17)}=1.28 ; p=0.273 \\
\text { Interaction: } F_{(1,17)}=0.11 ; p=0.743\end{array}$ \\
\hline $5 \alpha$-DHDOC & $0.87 \pm 0.24$ & $0.67 \pm 0.08$ & $0.71 \pm 0.12$ & $0.83 \pm 0.11$ & $\begin{array}{l}\text { Sex: } F_{(1,17)}=0.08 ; p=0.786 \\
\text { Genotype: } F_{(1,17)}=0.0001 ; p=0.992 \\
\text { Interaction: } F_{(1,17)}=1.38 ; p=0.257\end{array}$ \\
\hline $5 \beta-\mathrm{DHDOC}$ & ND & $4.11 \pm 0.77$ & ND & $5.21 \pm 0.82$ & \\
\hline $3 \alpha 5 \alpha$-THDOC & $0.75 \pm 0.05$ & $0.06 \pm 0.01^{* * *}$ & $0.33 \pm 0.06^{\$ \$ \$}$ & $0.12 \pm 0.04^{* *}$ & $\begin{array}{l}\text { Sex: } F_{(1,18)}=102.2 ; p<0.0001 \\
\text { Genotype: } F_{(1,18)}=16.2 ; p=0.0008 \\
\text { Interaction: } F_{(1,18)}=27.5 ; p<0.0001\end{array}$ \\
\hline $3 \alpha 5 \beta$-THDOC & ND & $1.00 \pm 0.27$ & ND & $1.41 \pm 0.29$ & \\
\hline Corticosterone & $47.6 \pm 4.73$ & $32.5 \pm 4.66$ & $19.4 \pm 3.05^{\$ \$ \$}$ & $34.2 \pm 4.29$ & $\begin{array}{l}\text { Sex: } F_{(1,18)}=0.001 ; p=0.979 \\
\text { Genotype: } F_{(1,18)}=9.86 ; p=0.006 \\
\text { Interaction: } F_{(1,18)}=12.6 ; p=0.002\end{array}$ \\
\hline Testosterone & $0.09 \pm 0.002$ & $0.01 \pm 0.004^{*}$ & $0.11 \pm 0.03$ & $0.01 \pm 0.004^{* *}$ & $\begin{array}{l}\text { Sex: } F_{(1,14)}=23.7 ; p=0.0003 \\
\text { Genotype: } F_{(1,14)}=0.41 ; p=0.533 \\
\text { Interaction: } F_{(1,14)}=0.52 ; p=0.482\end{array}$ \\
\hline $5 \alpha-\mathrm{DHT}$ & $0.03 \pm 0.01$ & $0.02 \pm 0.01$ & $0.03 \pm 0.01$ & $0.02 \pm 0.01$ & $\begin{array}{l}\text { Sex: } F_{(1,16)}=2.41 ; p=0.141 \\
\text { Genotype: } F_{(1,16)}=0.02 ; p=0.901 \\
\text { Interaction: } F_{(1,16)}=0.15 ; p=0.704\end{array}$ \\
\hline $3 \alpha 5 \alpha$-ТНТ & $0.01 \pm 0.003$ & $0.002 \pm 0.00002^{* *}$ & $0.007 \pm 0.004$ & $0.002 \pm 0.00004$ & $\begin{array}{l}\text { Sex: } F_{(1,16)}=13.3 ; p=0.002 \\
\text { Genotype: } F_{(1,16)}=1.85 ; p=0.193 \\
\text { Interaction: } F_{(1,16)}=1.83 ; p=0.195\end{array}$ \\
\hline Estradiol & $0.02 \pm 0.0003$ & $0.01 \pm 0.002$ & $0.01 \pm 0.002$ & $0.01 \pm 0.001$ & $\begin{aligned} \text { Sex: } F_{(1,16)}=0.89 ; p=0.361 \\
\text { Genotype: } F_{(1,16)}=2.24 ; p=0.154 \\
\text { Interaction: } F_{(1,16)}=3.89 ; p=0.066 \\
\\
\text { (Table continues) }\end{aligned}$ \\
\hline
\end{tabular}


Table 5. Continued

\begin{tabular}{|c|c|c|c|c|c|}
\hline \multirow[b]{2}{*}{ Steroid } & \multicolumn{2}{|l|}{$P R^{\text {IoxP/loxP }}$} & \multicolumn{2}{|l|}{$\mathrm{PR}^{\text {Nescre }}$} & \multirow[b]{2}{*}{ Two-way ANOVA } \\
\hline & Males & Females & Males & Females & \\
\hline \multicolumn{6}{|l|}{ Plasma (ng/ml) } \\
\hline Pregnenolone & $0.35 \pm 0.07$ & $0.39 \pm 0.02$ & $0.23 \pm 0.03$ & $0.36 \pm 0.12$ & $\begin{array}{l}\text { Sex: } F_{(1,17)}=1.54 ; p=0.232 \\
\text { Genotype: } F_{(1,17)}=1.33 ; p=0.265 \\
\text { Interaction: } F_{(1,17)}=0.51 ; p=0.486\end{array}$ \\
\hline Progesterone & $0.52 \pm 0.08$ & $0.51 \pm 0.09$ & $0.43 \pm 0.17$ & $0.33 \pm 0.02$ & $\begin{array}{l}\text { Sex: } F_{(1,18)}=0.34 ; p=0.565 \\
\text { Genotype: } F_{(1,18)}=2.46 ; p=0.134 \\
\text { Interaction: } F_{(1,18)}=0.29 ; p=0.598\end{array}$ \\
\hline $5 \alpha-\mathrm{DHP}$ & $9.66 \pm 0.61$ & $0.57 \pm 0.10^{* * *}$ & $8.85 \pm 0.66$ & $0.67 \pm 0.10^{* * *}$ & $\begin{array}{l}\text { Sex: } F_{(1,17)}=318.2 ; p<0.0001 \\
\text { Genotype: } F_{(1,17)}=0.54 ; p=0.471 \\
\text { Interaction: } F_{(1,17)}=0.90 ; p=0.357\end{array}$ \\
\hline $3 \alpha, 5 \alpha$-ТНP & $2.29 \pm 0.47$ & $0.18 \pm 0.07^{* * *}$ & $0.89 \pm 0.06^{\$ \$ \$}$ & $0.19 \pm 0.06$ & $\begin{array}{l}\text { Sex: } F_{(1,16)}=33.3 ; p<0.0001 \\
\text { Genotype: } F_{(1,16)}=8.05 ; p=0.012 \\
\text { Interaction: } F_{(1,16)}=8.30 ; p=0.011\end{array}$ \\
\hline $20 \alpha$-DHP & $1.51 \pm 0.19$ & $19.3 \pm 4.35^{* * *}$ & $0.64 \pm 0.11$ & $22.3 \pm 2.01^{* * *}$ & $\begin{array}{l}\text { Sex: } F_{(1,16)}=71.3 ; p<0.0001 \\
\text { Genotype: } F_{(1,16)}=0.22 ; p=0.645 \\
\text { Interaction: } F_{(1,16)}=0.71 ; p=0.412\end{array}$ \\
\hline $5 \alpha, 20 \alpha$-ТHP & $0.33 \pm 0.10$ & $0.17 \pm 0.06$ & $0.10 \pm 0.02$ & $0.18 \pm 0.01$ & $\begin{array}{l}\text { Sex: } F_{(1,16)}=0.33 ; p=0.575 \\
\text { Genotype: } F_{(1,16)}=3.28 ; p=0.089 \\
\text { Interaction: } F_{(1,16)}=3.96 ; p=0.064\end{array}$ \\
\hline $5 \beta-\mathrm{DHP}$ & ND & $0.11 \pm 0.01$ & $0.01 \pm 0.002$ & $0.10 \pm 0.02$ & \\
\hline $3 \beta 5 \alpha$-ТHP & $0.03 \pm 0.01$ & $0.002 \pm 0.001^{* *}$ & $0.005 \pm 0.001^{\$ \$}$ & $0.004 \pm 0.002$ & $\begin{array}{l}\text { Sex: } F_{(1,17)}=9.21 ; p=0.008 \\
\text { Genotype: } F_{(1,17)}=6.24 ; p=0.023 \\
\text { Interaction: } F_{(1,17)}=7.49 ; p=0.014\end{array}$ \\
\hline $3 \alpha 5 \beta$-ТНP & $0.01 \pm 0.002$ & $0.24 \pm 0.02^{* * *}$ & $0.01 \pm 0.002$ & $0.31 \pm 0.02^{* * * \$ \$}$ & $\begin{array}{l}\text { Sex: } F_{(1,13)}=338.9 ; p<0.0001 \\
\text { Genotype: } F_{(1,13)}=5.62 ; p=0.034 \\
\text { Interaction: } F_{(1,13)}=5.71 ; p=0.033\end{array}$ \\
\hline $3 \alpha 5 \alpha 20 \alpha-H H P$ & $1.02 \pm 0.28$ & $0.71 \pm 0.20$ & $0.27 \pm 0.02$ & $0.50 \pm 0.03$ & $\begin{array}{l}\text { Sex: } F_{(1,16)}=0.04 ; p=0.839 \\
\text { Genotype: } F_{(1,16)}=6.31 ; p=0.023 \\
\text { Interaction: } F_{(1,16)}=2.10 ; p=0.167\end{array}$ \\
\hline $3 \beta 5 \alpha 20 \alpha-\mathrm{HHP}$ & $0.12 \pm 0.04$ & $0.03 \pm 0.003^{* *}$ & $0.02 \pm 0.002^{\$}$ & $0.02 \pm 0.005$ & $\begin{array}{l}\text { Sex: } F_{(1,15)}=4.28 ; p=0.056 \\
\text { Genotype: } F_{(1,15)}=6.74 ; p=0.020 \\
\text { Interaction: } F_{(1,15)}=4.61 ; p=0.049\end{array}$ \\
\hline $3 \alpha 5 \beta 20 \alpha-\mathrm{HHP}$ & ND & $0.14 \pm 0.06^{*}$ & ND & $0.32 \pm 0.02 * * \$ 5$ & \\
\hline $20 \alpha$-DHPREG & $0.02 \pm 0.003$ & $0.02 \pm 0.005$ & $0.02 \pm 0.004$ & $0.02 \pm 0.003$ & $\begin{array}{l}\text { Sex: } F_{(1,16)}=0.39 ; p=0.540 \\
\text { Genotype: } F_{(1,16)}=2.18 ; p=0.160 \\
\text { Interaction: } F_{(1,16)}=0.14 ; p=0.715\end{array}$ \\
\hline DOC & $0.15 \pm 0.03$ & $0.63 \pm 0.22$ & $0.14 \pm 0.05$ & $0.83 \pm 0.25^{*}$ & $\begin{array}{l}\text { Sex: } F_{(1,18)}=12.1 ; p=0.003 \\
\text { Genotype: } F_{(1,17)}=0.30 ; p=0.593 \\
\text { Interaction: } F_{(1,17)}=0.43 ; p=0.518\end{array}$ \\
\hline $5 \alpha-\mathrm{DHDOC}$ & $5.09 \pm 1.31$ & $1.26 \pm 0.12^{*}$ & $3.34 \pm 0.83$ & $1.13 \pm 0.22$ & $\begin{array}{l}\text { Sex: } F_{(1,16)}=12.7 ; p=0.003 \\
\text { Genotype: } F_{(1,16)}=1.24 ; p=0.282 \\
\text { Interaction: } F_{(1,16)}=0.92 ; p=0.352\end{array}$ \\
\hline $5 \beta$-DHDOC & ND & $1.87 \pm 0.33$ & ND & $3.99 \pm 1.60$ & \\
\hline $3 \alpha 5 \alpha$-THDOC & $0.97 \pm 0.24$ & $0.02 \pm 0.01^{* *}$ & $0.57 \pm 0.14$ & $0.06 \pm 0.02$ & $\begin{array}{l}\text { Sex: } F_{(1,15)}=20.4 ; p=0.0004 \\
\text { Genotype: } F_{(1,15)}=1.24 ; p=0.283 \\
\text { Interaction: } F_{(1,15)}=1.87 ; p=0.192\end{array}$ \\
\hline $3 \alpha 5 \beta$-THDOC & $<0.005$ & $0.14 \pm 0.04$ & $<0.005$ & $0.58 \pm 0.27$ & \\
\hline Corticosterone & $82.1 \pm 4.78$ & $65.1 \pm 11.2$ & $46.8 \pm 6.20^{5}$ & $76.2 \pm 6.72$ & $\begin{array}{l}\text { Sex: } F_{(1,17)}=0.55 ; p=0.469 \\
\text { Genotype: } F_{(1,17)}=2.09 ; p=0.167 \\
\text { Interaction: } F_{(1,17)}=7.64 ; p=0.013\end{array}$ \\
\hline Testosterone & $0.10 \pm 0.02$ & $0.002 \pm 0.00003^{* * *}$ & $0.11 \pm 0.03$ & $0.01 \pm 0.005^{* * *}$ & $\begin{array}{l}\text { Sex: } F_{(1,17)}=46.1 ; p<0.0001 \\
\text { Genotype: } F_{(1,17)}=0.42 ; p=0.523 \\
\text { Interaction: } F_{(1,17)}=0.01 ; p=0.913\end{array}$ \\
\hline $5 \alpha-\mathrm{DHT}$ & $0.01 \pm 0.001$ & $0.002 \pm 0.00002^{* * * *}$ & $0.01 \pm 0.003$ & $0.002 \pm 0.00003^{* *}$ & $\begin{array}{l}\text { Sex: } F_{(1,17)}=36.5 ; p<0.0001 \\
\text { Genotype: } F_{(1,17)}=0.84 ; p=0.373 \\
\text { Interaction: } F_{(1,17)}=0.78 ; p=0.389\end{array}$ \\
\hline $3 \alpha 5 \alpha$-ТНТ & $0.02 \pm 0.002$ & $0.003 \pm 0.001^{*}$ & $0.03 \pm 0.004$ & $0.01 \pm 0.01^{*}$ & $\begin{array}{l}\text { Sex: } F_{(1,17)}=17.7 ; p=0.0006 \\
\text { Genotype: } F_{(1,17)}=2.72 ; p=0.117 \\
\text { Interaction: } F_{(1,17)}=0.002 ; p=0.969\end{array}$ \\
\hline Estradiol & $0.01 \pm 0.001$ & $0.01 \pm 0.001$ & $0.01 \pm 0.001$ & $0.01 \pm 0.003$ & $\begin{array}{l}\text { Sex: } F_{(1,17)}=0.11 ; p=0.741 \\
\text { Genotype: } F_{(1,17)}=0.31 ; p=0.587 \\
\text { Interaction: } F_{(1,17)}=2.30 ; p=0.148\end{array}$ \\
\hline
\end{tabular}


A

Pregnenolone

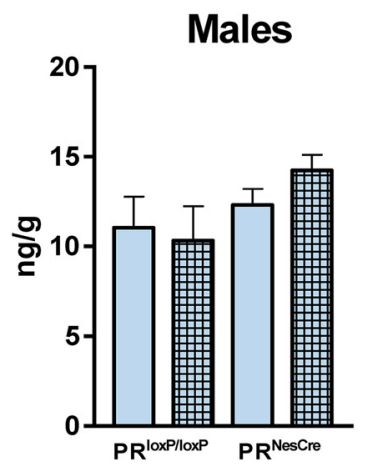

Females

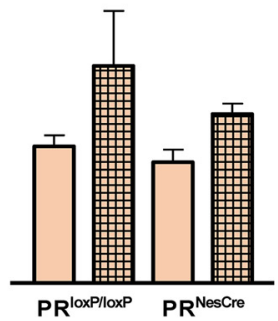

C

5a-DHP

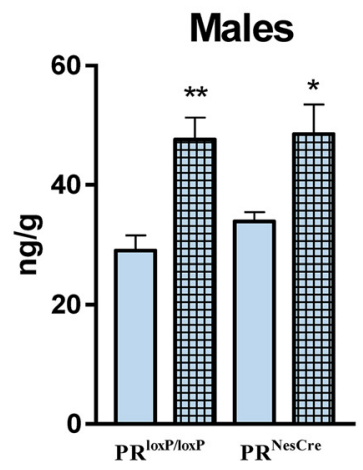

Females

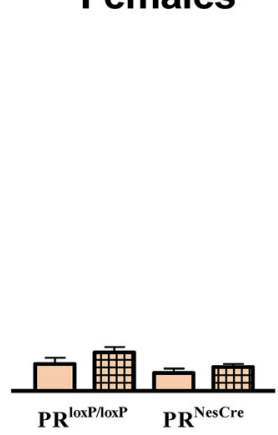

B

Progesterone
E

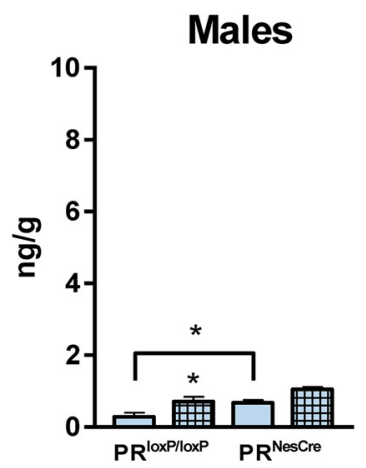

M Sham
20a-DHP

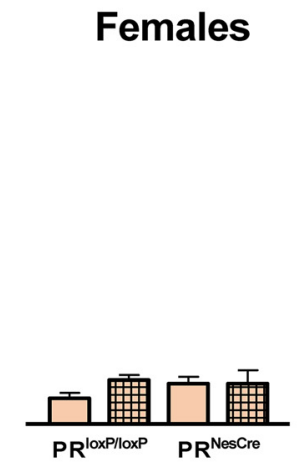

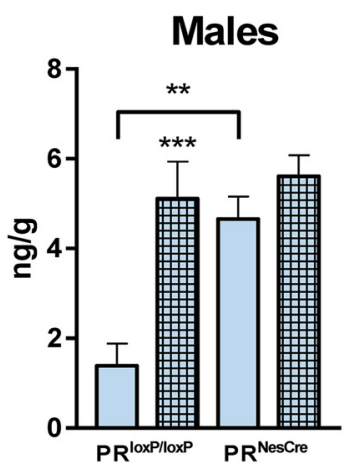

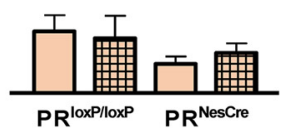

$3 \alpha, 5 \alpha-T H P$

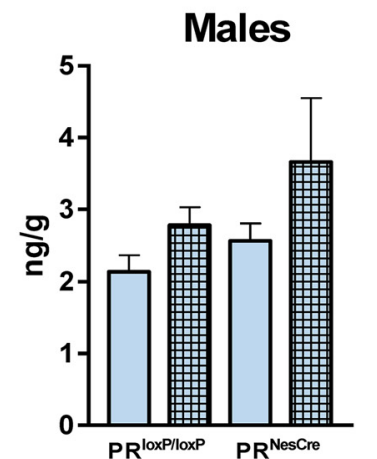

Females

F

$5 \alpha, 20 \alpha-T H P$

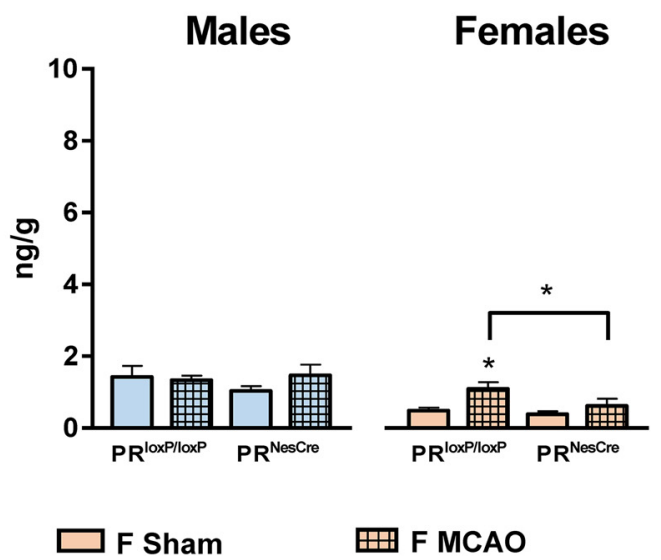

Figure 6. Levels of pregnenolone and progesterone and its major metabolites were analyzed by GC-MS/MS in the left hemisphere of males and females PR ${ }^{\text {loxP/loxP }}$ and $P R^{\text {Nescre }}$ mice at $6 \mathrm{~h}$ after sham operation or MCAO. A, Levels of pregnenolone did not differ significantly between sexes and genotypes and were not affected by MCA0. $\boldsymbol{B}$, Levels of progesterone were upregulated significantly in response to $M C A 0$ in $P R^{\text {loxP/loxP }}$ males. In contrast to $P R^{\text {loxP/loxP }}$ males, brain levels of progesterone were elevated after sham surgery and MCAO in PR ${ }^{\text {NesCre }}$ males (effect of MCAO: $F_{(1,19)}=15.1, p=0.001$; effect of genotype: $F_{(1,19)}=9.85, p=0.005$; interaction between MCA0 and genotype: $\left.F_{(1,19)}=5.29, p=0.033\right)$. In females, levels of progesterone were lower compared with males and similar in sham and MCAO mice of both genotypes. C, Levels of $5 \alpha$-DHP were much higher in males than in females and were only increased in response to $M C A 0$ in males (effect of MCA0 in males: $F_{(1,21)}=23.1, p<0.0001$ ). There were no differences for $5 \alpha$-DHP levels between PR loxP/loxP and PR ${ }^{\text {NesCre }}$ mice. $D$, As for $5 \alpha$-DHP, brain levels of $3 \alpha, 5 \alpha$-THP were much higher in males than in females. Neither in males nor in females was there an effect of MCAO or genotype. $E$, Similar low levels of $20 \alpha-D H P(<2 \mathrm{ng} / \mathrm{g})$ were measured in the brain of PR ${ }^{\text {loxP/loxP }}$ and $P R^{\text {Nescre }}$ males and females after sham surgery or MCA0. However, despite the low levels of $20 \alpha$-DHP, they were upregulated significantly after MCA0 in PR ${ }^{\text {loxP } / l o x P}$ males and were higher in sham-operated PR ${ }^{\text {Nescre }}$ males compared with sham-operated PR ${ }^{\text {loxP/loxP }}$ males (effect of MCAO in males: $F_{(1,21)}=13.9, p=0.001$; effect of genotype in males: $F_{(1,21)}=11.8, p=0.003$ ). $F_{1}$ As in the normal brain, levels of $5 \alpha, 20 \alpha$-THP were low after sham surgery or MCAO in both sexes. In females, $5 \alpha, 20 \alpha$-THP levels were slightly upregulated after MCAO in PR ${ }^{\text {loxP/loxP }}$ mice (effect of MCA0 in females: $F_{(1,19)}=8.29, p=0.010$; effect of genotype in females: $\left.F_{(1,19)}=3.94, p=0.062\right)$. Results are presented as means \pm SEM $(n=5-7$ per group) and were analyzed by 2 -way ANOVA (MCAO $\times$ genotype) for males and females separately followed by Newman-Keuls multiple-comparisons tests. ${ }^{* *} p<0.001,{ }^{* *} p<0.01,{ }^{*} p<0.05$ compared with sham or as indicated. 


\section{Young}

A

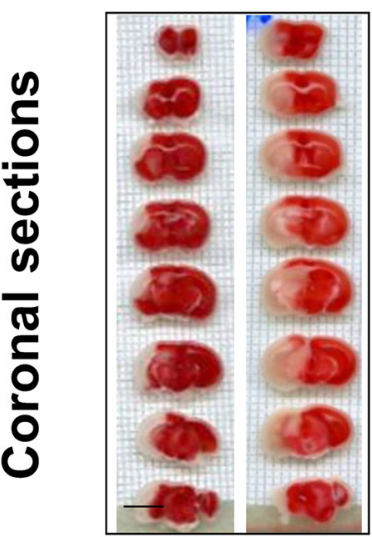

PR
Females

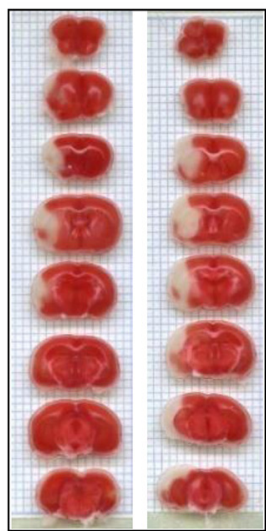

IoxP/loxP NesCre
B

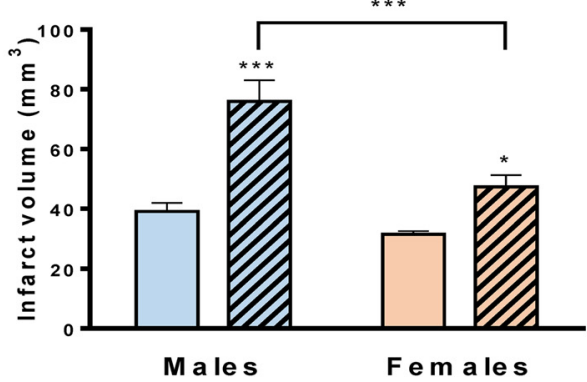

C

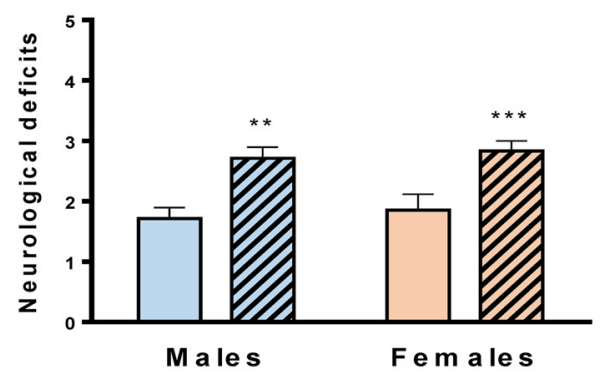

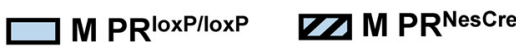

D

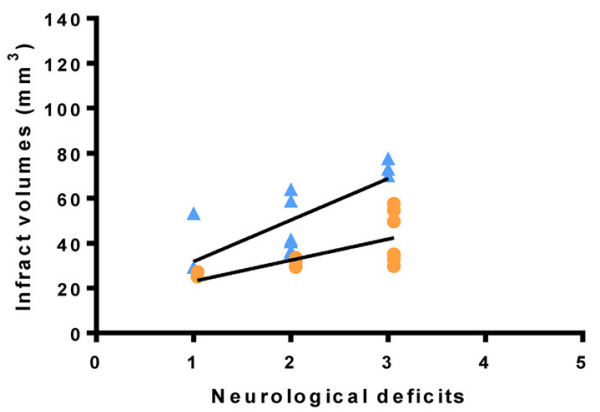

$\triangle$ Males
E

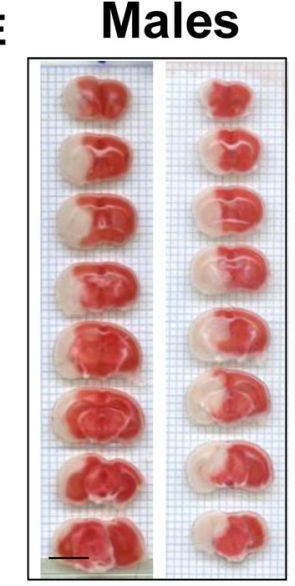

loxP/loxP NesCre
Aging

Females

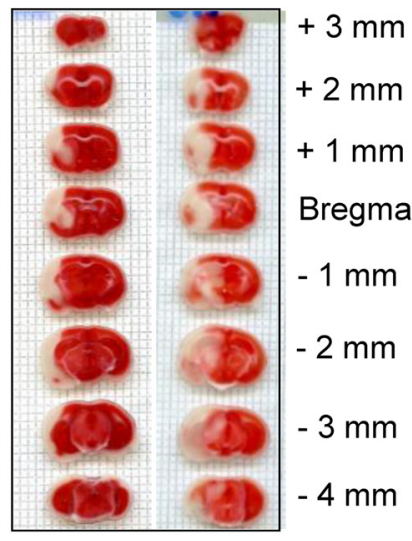

$\mathbf{F}$

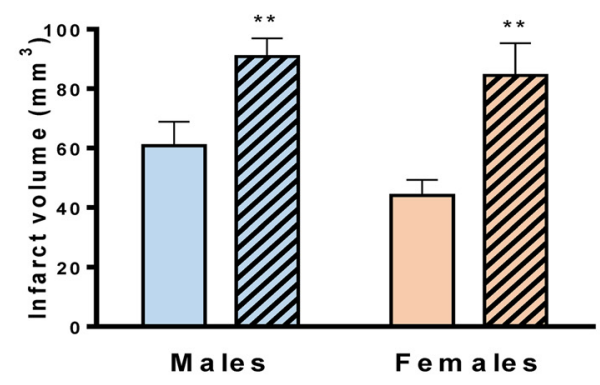

G

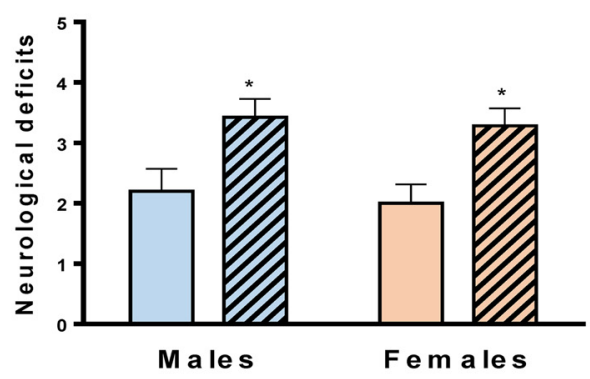

\section{F PR PRP/loxP $^{\text {lox }}$ PR $^{\text {NesCre }}$}

H

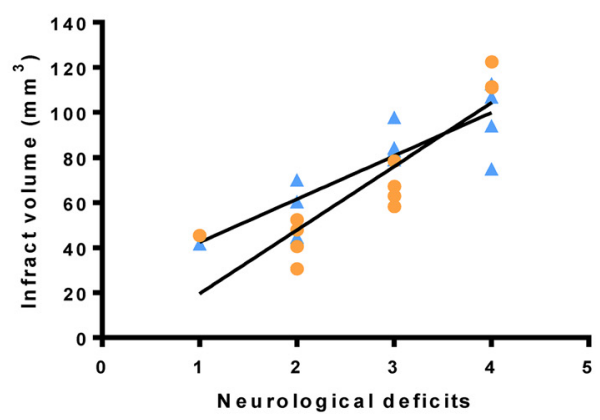

Females

Figure 7. Infarct volumes and neurological deficits at $6 \mathrm{~h}$ after MCAO were increased in young and aging mice of both sexes after deletion of PR in the brain. Total infarct volumes and neurological deficit scores (higher scores reflect higher disability) were analyzed in young $(\boldsymbol{A}-\boldsymbol{D})$ and aging $(\boldsymbol{E}-\boldsymbol{H}) \mathrm{PR}^{\text {loxP/loxP }}$ and PR Nescre mice. $\boldsymbol{A}, \boldsymbol{E}$, Representative 1-mm-thick coronal brain sections of young and aging male and female PR ${ }^{\text {loxP/loxP }}$ and PR ${ }^{\text {NesCre }}$ mice stained with 2,3,5-triphenyltetrazolium chloride. Infarcted tissue appears pale and normal tissue is colored dark red. Scale bar, $5 \mathrm{~mm}$. $\boldsymbol{B}$, In young males and females, total infarct volumes were significantly larger in $P R^{\text {Nescre }}$ mice compared with PR ${ }^{\text {loxP/loxP }}$ mice. However, for PR ${ }^{\text {Nescre }}$ mice, the infarct (Figure legend continues.) 
differences between $\mathrm{PR}^{\text {loxP/loxP }}$ and $\mathrm{PR}^{\text {NesCre }}$ mice became even

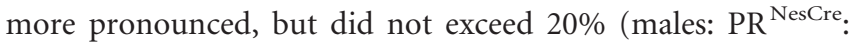
$28.3 \pm 0.3 \mathrm{~g} ; \mathrm{PR}^{\text {loxP/loxP }}: 35.1 \pm 1.1 \mathrm{~g}$; females: $\mathrm{PR}^{\text {NesCre }}: 27.3 \pm$ $0.8 \mathrm{~g}$; $\mathrm{PR}^{\text {loxP/loxP }}: 31.3 \pm 1.5 \mathrm{~g}$, means \pm SEM; effect of sex: $F_{(1,31)}=$ 5.55, $p<0.05$; effect of genotype: $\left.F_{(1,31)}=28.5, p<0.001\right)$. Therefore, during aging, $\mathrm{PR}^{\mathrm{Nes} C r e}$ mice of both sexes gain less weight.

Male $\mathrm{PR}^{\mathrm{Nes} C \mathrm{Cre}}$ mice showed normal fertility when mated with female $P R^{\text {loxP/loxP }}$ mice. Of eight pairs, all produced a number of offspring comparable to wild-types. In contrast, $P R^{\text {NesCre }}$ females exhibited significantly reduced fertility when mated with $\mathrm{PR}^{\text {loxP/loxP }}$ males. Over a 3-month observation period, only 4 females of 24 produced offspring and the size of their litters did not exceed 2 pups. One reason for this low fertility of $\mathrm{PR}^{\mathrm{Nes} C r e}$ females was their irregular estrus cycles as determined by vaginal cytology and a markedly reduced number of corpus lutea within the ovaries of $\mathrm{PR}^{\mathrm{Nes} C r e}$ females. This reproductive phenotype is consistent with the previously reported inability of total PR knock-out mice to ovulate (Lydon et al., 1995).

\section{Steroid profiling in brain and plasma of young adult $\mathrm{PR}^{\text {loxP/loxP }}$ and $P R^{\text {NesCre }}$ mice of both sexes}

To assess whether conditional inactivation of PR in neural cells of the CNS had an impact on steroid levels, extended brain and plasma profiles were established by GC-MS/MS for young (3 months old) male and female $\mathrm{PR}^{\text {loxP/loxP }}$ and $\mathrm{PR}^{\text {NesCre }}$ mice (Table 5). Both $P R^{\text {loxP/loxP }}$ and $P R^{\text {NesCre }}$ females were again sampled according to vaginal cytology at the diestrus stage.

Levels of the major steroids measured in the $\mathrm{PR}^{\text {loxP/loxP }}$ and $\mathrm{PR}^{\text {NesCre }}$ mice were comparable to those reported in Figure 2 and Table 3 for wild-type C57BL/6 mice. Levels of pregnenolone were much higher in brain than in plasma, whereas similar low levels of progesterone were measured. Important for our purpose was the confirmation of much higher levels of PR active $5 \alpha$-DHP in the male brain compared with females and plasma (Table 5). Furthermore, levels of $20 \alpha$-DHP in brain and plasma were $\sim 10-20$ times higher in females compared with males. However, absolute levels of $20 \alpha$-DHP in this experiment were much higher than those shown in Figure 2. This difference may not necessarily reflect strain variations, but it may have been caused by higher

\footnotetext{
$\leftarrow$

(Figure legend continued.) volume was significantly larger in males than in females. Data analysis by two-way ANOVA revealed significant effects of genotype $\left(F_{(1,23)}=36.7, p<0.0001\right)$ and sex $\left(F_{(1,23)}=17.4, p=0.0004\right)$, as well as a significant interactions between both factors $\left(F_{(1,23)}=5.89, p=0.024\right)$. C, Neurological deficits were analyzed by Kruskal-Wallis ANOVA $(p=0.003)$. In both sexes, neurological deficits were greater in PR ${ }^{\text {Nescre }}$ mice compared with $P R^{\text {loxP/loxP }}$ mice. $D$, Spearman's test showed highly positive correlations between neurological deficit scores and infarct volumes for males $(r=0.86, p=0.0003)$ and females $(r=0.70, p=$ 0.009). $\boldsymbol{F}$, In aging males and females, total infarct volumes were significantly larger in PR Nes(re mice compared with $P R^{\text {loxP/loxP }}$ mice. In contrast to young mice, infarct volumes were comparable between males and females. Indeed, two-way ANOVA only showed a significant effect of genotype $\left(F_{(1,20)}=18.7, p=0.0003\right)$. However, infarct volumes were larger in aging mice compared with young mice, as revealed by a two-way ANOVA with age and sex as factors (effect of age: $P R^{\text {loxP/loxP }}$ mice: $F_{(1,20)}=15.2, p=0.0009 ; \mathrm{PR}^{\text {Nescre }}$ mice: $F_{(1,23)}=12.6, p=0.002$ ). $G$, As for young mice, neurological deficits were greater in $P R^{\text {Nescre }}$ mice compared with $P R^{\text {loxP } P \text { loxP }}$ mice ( $p=0.017$ by Kruskal-Wallis analysis). Interestingly, neurological deficits were higher in aging than in young $\mathrm{PR}^{\text {Nes(re }}$ mice ( $p=0.018$ by Mann-Whitney test), but there was no such effect of age on functional outcomes in PR ${ }^{\text {loxP/loxP }}$ mice. $\boldsymbol{H}$, Spearman's test showed strong positive correlations between neurological deficit scores and infarct volumes for both aging males $(r=0.81, p=0.002)$ and females $(r=0.92, p<0.001)$. Results are presented as means \pm SEM ( $n=5-7$ per group). Two-way ANOVA (sex $\times$ genotype) followed by Newman-Keuls multiple-comparisons tests were used for infarct volume analysis. ${ }^{* *} p<0.001$, ${ }^{* *} p<0.01,{ }^{*} p<0.05$ compared with $P R^{\text {loxP/loxP }}$ mice or as indicated.
}

levels of stress and adrenal activity. Indeed, levels of the stress response hormone corticosterone were also elevated in the present experiment. Results further confirm higher levels of $5 \beta$-reduced metabolites of progesterone and DOC in females compared with males.

Importantly, steroid levels were comparable between $\mathrm{PR}{ }^{\text {loxP/loxP }}$ and $\mathrm{PR}^{\mathrm{Nes} C r e}$ mice for PR-active progesterone and $5 \alpha$-DHP (Table 5). However, plasma and brain levels of corticosterone were lower in $\mathrm{PR}^{\text {NesCre }}$ males compared with $\mathrm{PR}^{\text {loxP/loxP }}$ males. This may also have contributed to the slightly reduced levels of some $5 \alpha$-reduced metabolites of progesterone and DOC in $\mathrm{PR}^{\mathrm{Nes} C r e}$ mice.

\section{Changes in brain levels of progesterone and its metabolites} after MCAO in male and female $P^{10 x P / l o x P}$ and $P^{\text {NesCre }}$ mice $\mathrm{PR}^{\mathrm{Nes} C r e}$ mice were generated to uncover the cerebroprotective effects of endogenous brain progesterone and $5 \alpha$-DHP, both active PR ligands, in males. It was thus important to examine whether levels of progesterone and its active metabolites were increased rapidly after MCAO in the transgenic male $\mathrm{PR}^{\text {loxP/loxP }}$ and $\mathrm{PR}^{\mathrm{Nes} C \mathrm{Cre}}$ mice, as they are in wild-type males (Fig. 3). Brain levels of progesterone and its major reduced metabolites were analyzed by GC-MS/MS in the left infarcted hemisphere of $\mathrm{PR}^{\text {loxP/loxP }}$ and $\mathrm{PR}^{\text {NesCre }}$ male and female mice at $6 \mathrm{~h}$ after sham surgery or MCAO.

Analysis by GC-MS/MS revealed similar steroid profiles for $\mathrm{PR}^{\text {loxP/loxP }}$ and $\mathrm{PR}^{\mathrm{Nes} C r e}$ mice at $6 \mathrm{~h}$ after sham surgery or MCAO (Fig. 6). However, brain levels of both progesterone and $20 \alpha$ DHP were significantly higher in sham-operated $\mathrm{PR}^{\text {NesCre }}$ males compared with sham-operated $\mathrm{PR}^{\operatorname{lox} \mathrm{P} / \mathrm{lox} P}$ males, suggesting a greater sensitivity of the former to surgical stress (Fig. 6B,E). After MCAO, brain levels of progesterone were elevated in the male brain and they were three times higher in males than in females (Fig. 6B). Brain levels of $5 \alpha$-DHP were nearly 10 times higher in males compared with females and were upregulated markedly at $6 \mathrm{~h}$ after MCAO in males compared with sham operation (Fig. 6C). No increases in the levels of progesterone and $5 \alpha$-DHP were found after MCAO in females, consistent with results presented in Figure 3 for C57BL/6 mice. Levels of $3 \alpha, 5 \alpha-$ THP were also higher in males than in females, but were not upregulated in response to MCAO (Fig. 6D). Levels of $20 \alpha$-DHP and $5 \alpha, 20 \alpha$-THP were low in both sham- and MCAO-operated males and females (Fig. 6E,F).

Therefore, the response of brain steroids to MCAO surgery differs between sexes. Whereas males upregulate the production of PR active progesterone and $5 \alpha$-DHP in response to ischemic injury, females do not show such changes.

\section{Resistance of the brain to ischemic damage is reduced in young male and female $\mathrm{PR}^{\text {NesCre }}$ mice}

For all of the outcomes measured after MCAO, we first verified that they were similar for C57BL/6 and PR ${ }^{\operatorname{lox} / / \operatorname{lox} P}$ mice. Neurological scores, time spent on the rotarod, and infarct volumes did not differ significantly between the two strains of mice and we used $\mathrm{PR}^{\text {loxP/loxp }}$ mice as controls for the effect of targeted $\mathrm{PR}$ inactivation in the CNS.

If the endogenous PR ligands progesterone and $5 \alpha$-DHP play a role in rapid endogenous cerebroprotective mechanisms, then deletion of PRs in the brain could be expected to reduce its resistance to ischemic injury. We therefore compared the total infarct volume, neurological outcomes, neuron densities, and microglial activation between young male and female $\mathrm{PR}^{\text {loxP/loxP }}$ and $\mathrm{PR}^{\text {NesCre }}$ mice at $6 \mathrm{~h}$ after MCAO (Figs. 7, 8, 9, left). Although sham surgery seemed to have an influence on the brain levels of some proges- 
A

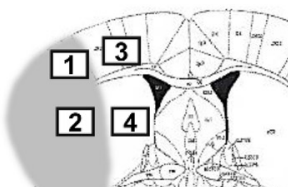
Young

A

B 1
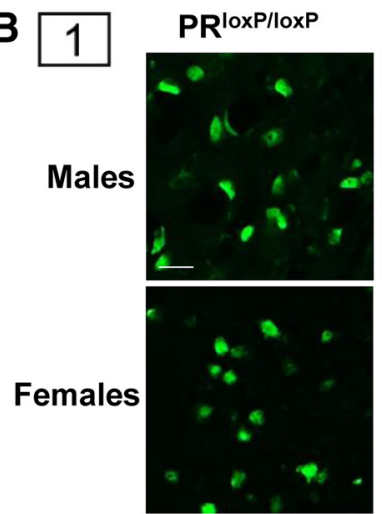

C 1

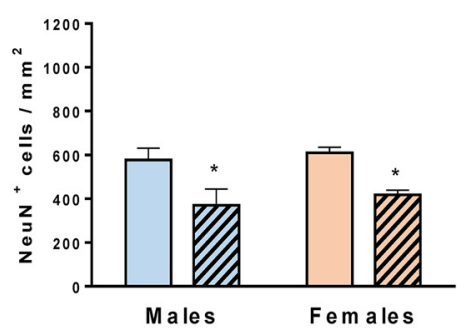

D 2

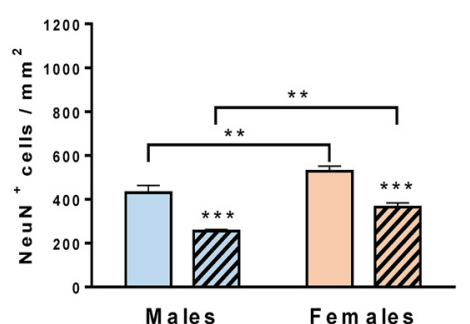

E 3

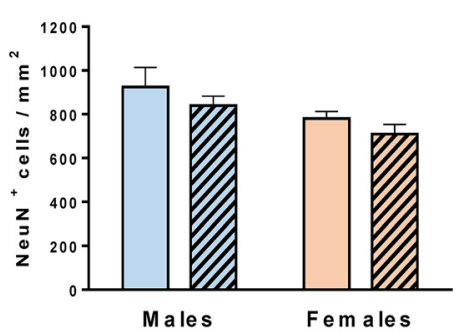

F 4

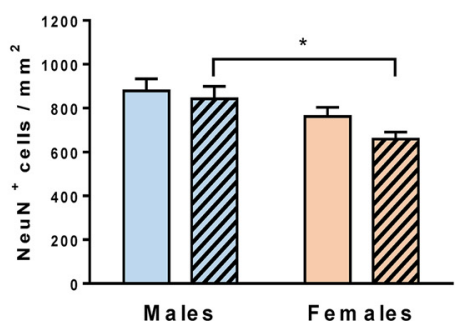

$\square$ M PR loxP/loxP
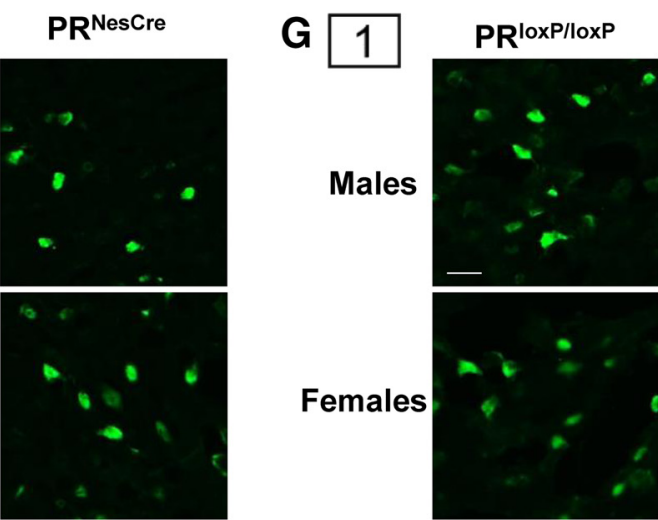

Females
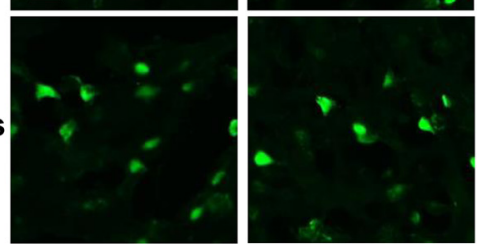

H 1
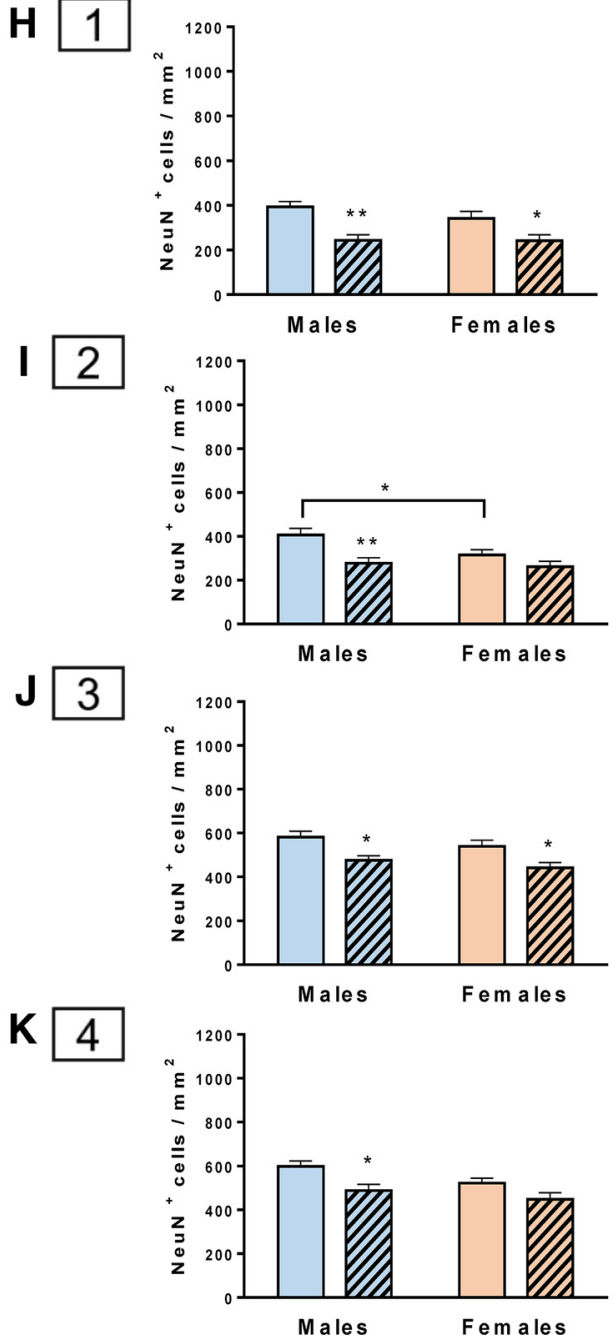

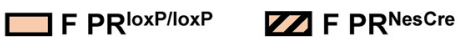

Figure 8. The density of $\mathrm{NeuN}^{+}$neurons at $6 \mathrm{~h}$ after MCAO was decreased in the ipsilateral ischemic hemisphere in young and aging mice after deletion of PR in the brain. $A$, Localization of the four regions where neurons were counted at the level of the cerebral cortex and striatum. The regions were located on the infarct and peri-infarct, which were delimited by DAPI staining of cell nuclei. The regions are drawn on a coronal brain section taken from the atlas of Franklin and Paxinos (2008) at the level of bregma +0.14 . The infarct (Figure legend continues.) 
terone metabolites, it did not cause ischemic damage. Indeed, sham surgery did not affect cerebral blood flow, neurological deficit scores, or infarct volume.

Infarct volumes were increased significantly in $\mathrm{PR}^{\mathrm{Nes} C r e}$ mice of both sexes compared with $\mathrm{PR}^{\text {loxP/loxP }}$ mice (Fig. $7 A, B$ ). In males, the size of the infarct was nearly doubled after deletion of $\mathrm{PRs}$, whereas in $\mathrm{PR}^{\text {NesCre }}$ females, the infarct was increased by $30 \%$. Infarct volumes did not differ between sexes in $\mathrm{PR}^{\text {loxP/loxP }}$ mice, but were significantly larger in male than in female $P R^{\text {NesCre }}$ mice (Fig. 7B), pointing to the existence of additional PRindependent protective mechanisms in females.

Neurological deficits were assessed on a six-point scale, with elevated scores reflecting higher functional disability (Gibson et al., 2011). In contrast to the infarct size, they were similarly increased in male and female $\mathrm{PR}^{\text {NesCre }}$ males compared with $\mathrm{PR}^{\text {loxP/loxP }}$ mice (Fig. 7C). Therefore, endogenous PR-dependent signaling contributed to the preservation of neural functions in both sexes. Highly positive correlations were observed between infarct volumes and neurological deficits in both sexes (Fig. 7D).

To go further in the evaluation of the tissue damage at $6 \mathrm{~h}$ after $\mathrm{MCAO}$, the density of neurons labeled with an antibody against the neuronal nuclear antigen NeuN was measured by immunofluorescence analysis. Neurons were counted in the infarct and in the peri-infarct at the levels of the cerebral cortex and striatum (Fig. $8 A, B$ ). In both brain regions, MCAO is known to produce widespread ischemic cell death, with the most rapid damage occurring in the striatum (Carmichael, 2010). DAPI counterstaining of cell nuclei allowed us to define the demarcation between the infarct and peri-infarct areas.

\footnotetext{
$\leftarrow$

(Figure legend continued.) area is schematically presented in gray. $\boldsymbol{B}, \mathbf{G}$, Representative immunofluorescence staining of $\mathrm{NeuN}^{+}$neurons in region 1 (infarct in the cerebral cortex) of young and aging $P R^{\text {loxP/loxP }}$ and $P R^{\text {Nescre }}$ mice of both sexes. Scale bar, $100 \mu \mathrm{m}$. $\boldsymbol{B}-\boldsymbol{F}$, Neuronal density in young mice. $\boldsymbol{C}$, In region 1 (infarct in the cerebral cortex), there were no differences between males and females, but the density of $\mathrm{NeuN}^{+}$neurons was significantly lower in $P R^{\text {Nescre }}$ mice compared with PR ${ }^{\text {loxP/loxP }}$ mice (two-way ANOVA with sex and genotype as factors; effect of genotype: $\left.F_{(1,20)}=20.1, p=0.0002\right)$. $\boldsymbol{D}$, In region 2 (infarct in the striatum), the density of NeuN ${ }^{+}$neurons was also significantly lower in $\mathrm{PR}^{\text {Nescre }}$ mice compared with $P R^{\text {loxP/loxP }}$ mice (effect of genotype: $F_{(1,20)}=48.8, p<0.0001$ ) for both sexes. However, neuron density was slightly but significantly higher in females than in males for both $P R$ loxP/loxP and $P R^{\text {Nescre }}$ mice (effect of sex: $\left.F_{(1,20)}=18.3, p=0.0004\right) . \boldsymbol{E}, \boldsymbol{F}$, in the peri-infarct in the cerebral cortex $(\boldsymbol{E})$ and striatum $(\boldsymbol{F})$, neuronal density was about twice as high as at the infarct. There were no differences between $P R^{\text {loxP/loxP }}$ and $P R^{\text {Nescre }}$ mice, but the density of neurons tended to be higher in males (effect of sex in region $3: F_{(1,20)}=5.84, p=0.025$ and in region 4: $\left.F_{(1,20)}=10.2, p=0.005\right)$. $\mathbf{G}-\boldsymbol{K}$, Neuronal density in aging mice. $\boldsymbol{H}$, As in region 1 of young mice, the density of NeuN ${ }^{+}$neurons was significantly lower in $\mathrm{PR}^{\text {Nescre }}$ males and females compared with $P R^{\text {loxP } / 10 x P}$ mice (effect of genotype: $F_{(1,20)}=20.7, p=0.0002$ ). However, the density of neurons was lower in aging mice compared with young mice as revealed by a twoway ANOVA with age and sex as factors (effect of age: PR loxP/loxP mice: $F_{(1,19)}=37.8, p<$ $0.0001 ; \mathrm{PR}^{\mathrm{Nes}(r e}$ mice: $\left.F_{(1,21)}=16.7, p=0.0005\right) . I$, In region 2, the density of NeuN ${ }^{+}$neurons was significantly lower in $P R^{\text {Nescre }}$ males compared with $P R^{\text {loxP/loxP }}$ males (effect of genotype: $\left.F_{(1,20)}=11.7, p=0.003\right)$. Again, a two-way ANOVA with age and sex as factors showed that the density of neurons was lower in aging mice compared with young mice (effect of age: $\mathrm{PR}^{\text {loxP/loxP }}$ mice: $F_{(1,19)}=17.2, p=0.0006 ; \mathrm{PR}^{\text {Nes(re }}$ mice: $\left.F_{(1,21)}=3.20, p=0.088\right) . J, \boldsymbol{K}$, In contrast to the young mice, neuronal density was lower in the peri-infarct in cerebral cortex (J) and striatum $(\boldsymbol{K})$ of PR ${ }^{\text {Nescre }}$ mice compared with PR ${ }^{\text {loxP/loxP }}$ (effect of genotype in region 3: $F_{(1,20)}=16.7, p=0.0006$ and in region $\left.4: F_{(1,20)}=10.6, p=0.004\right)$. Again, the density of neurons was lower in the aging mice compared with the young mice $(p<0.001$ for regions 3 and 4 of PR Nes(re and PR LoxP/loxP mice). Results are presented as means \pm SEM ( $n=5-7$ per group) and were analyzed by Newman-Keuls multiple-comparisons tests after two-way ANOVA (sex $\times$ genotype). ${ }^{* * *} p<0.001,{ }^{* *} p<0.01,{ }^{*} p<0.05$ compared with $P R^{\text {loxP/loxP }}$ mice or as indicated.
}

At the infarct core in both cerebral cortex and striatum, neuron density was significantly lower in $\mathrm{PR}^{\mathrm{Nes} C r e}$ mice compared with $\mathrm{PR}^{\text {loxP/loxp }}$ mice for both sexes (Fig. $8 C, D$ ). At the periinfarct area, the density of neurons was almost twice that counted in the infarct core and no differences were observed between $\mathrm{PR}^{\mathrm{Nes} C r e}$ mice and $\mathrm{PR}^{\text {loxP/loxP }}$ mice (Fig. $8 E, F$ ). Similar neuronal densities with no differences between $\mathrm{PR}^{\text {NesCre }}$ mice and $\mathrm{PR}^{\text {loxP/loxP }}$ mice were also observed in the contralateral hemisphere. Sex differences in the density of $\mathrm{NeuN}^{+}$neurons were observed after MCAO in the striatum (Fig. $8 D, F$ ), but not in the cortex (Fig. 8C,E).

The density of activated microglia was assessed by immunofluorescence analysis of Ibal ${ }^{+}$cells in cerebral cortex and striatum. As early as $6 \mathrm{~h}$ after MCAO, microglial activation was only observed in the peri-infarct (Fig. 9B-D). In both cortex and striatum, the density of activated microglial cells was significantly lower in $\mathrm{PR}^{\text {NesCre }}$ mice compared with $\mathrm{PR}^{\text {loxP/loxP }}$ mice for both sexes (Fig. 9C,D). The density of Iba ${ }^{+}$microglial cells was low in the contralateral nonischemic side and was unaffected by the PR deletion (Fig. 9E,F).

\section{Resistance of the brain to ischemic damage is also reduced in aging male and female mice after deletion of PRs}

To determine whether the endogenous PR-dependent cerebroprotective mechanisms remain functional during aging, infarct volume, neurological outcomes, neuron densities, and microglial activation were examined at $6 \mathrm{~h}$ after MCAO in aging (12-14 months old) male and female $\mathrm{PR}^{\text {loxP/loxP }}$ and $\mathrm{PR}^{\text {NesCre }}$ mice (Figs. $7,8,9$, right) and were compared with the results obtained for young (3 months old) mice (Figs. 7, 8, 9, left).

In aging mice, the invalidation of PRs also resulted in larger infarct volumes and there were no differences between sexes (Fig. $7 E, F)$. As expected, infarct volumes were larger in aging compared with young mice (Fig. $7 B, F$ ). Neurological deficit scores were increased to the same extent in both sexes, reflecting higher functional disability (Fig. 7G). Interestingly, neurological deficits tended to be higher in aging than in young mice, but only for the $\mathrm{PR}^{\mathrm{Nes} C r e}$ mice. As for the young mice, positive correlations were observed between infarct volumes and neurological deficits (Fig. $7 H$ ). Therefore, endogenous PR signaling continues to play an important role in cerebroprotection in aging males and females.

Densities of neurons were lower in the aging males and females compared with young adults in infarct and peri-infarct areas of cortex and striatum (Fig. 8). Sex differences in the density of $\mathrm{NeuN}^{+}$neurons were only observed in the infarct at the level of the striatum in aging $\mathrm{PR}^{\text {loxP/loxP }}$ mice (Fig. $8 I$ ). Neuron density was significantly lower in $\mathrm{PR}^{\mathrm{Nes} C r e}$ mice compared with $\mathrm{PR}^{\text {loxP/loxP }}$ mice, not only in the infarct region, but also in the peri-infarct area (Fig. $8 H-K$ ), suggesting a more rapid spreading of the ischemic lesion in aging compared with young mice. The reduced number of neurons after inactivation of $\mathrm{PR}$ in the aging brain uncovered a role for endogenous PR signaling in neuroprotection in cerebral cortex and dorsal striatum in both infarct and peri-infarct.

Activated $\mathrm{Ibal}^{+}$microglial cells were observed in the periinfarct of aging mice at $6 \mathrm{~h}$ after MCAO (Fig. 9G-I). The density of $\mathrm{Ibal}^{+}$cells was lower in aging mice compared with young mice, at the level of the striatum. In both cerebral cortex and striatum, the density of activated microglial cells in the periinfarct was lower in $\mathrm{PR}^{\text {NesCre }}$ mice compared with $\mathrm{PR}^{\text {loxP/loxP }}$ mice, thus confirming a role of endogenous PR signaling in the activation of microglial responses (Fig. 9H,I). In the contralateral nonischemic side of the cerebral cortex and striatum, the 
A

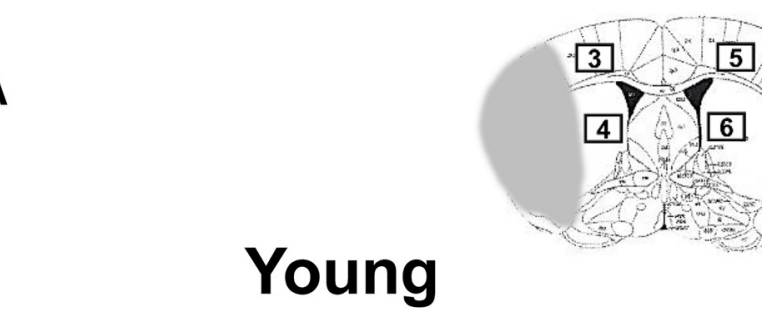

B
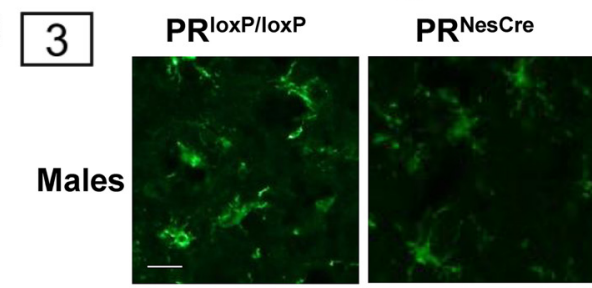

Females

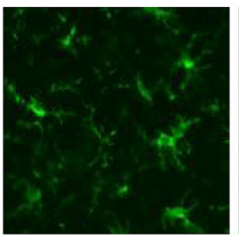

C 3

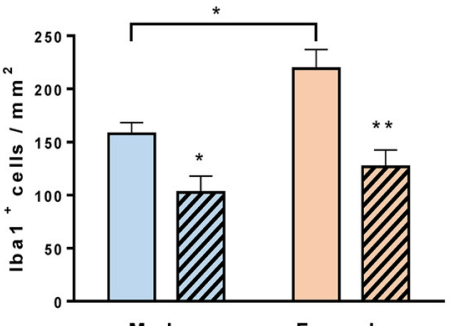

D 4

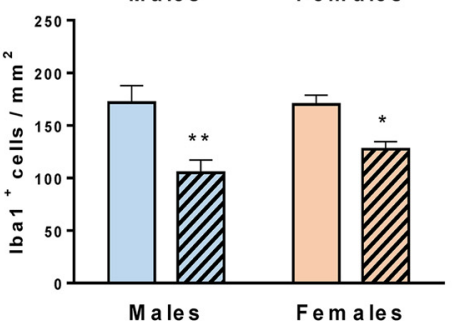

E 5

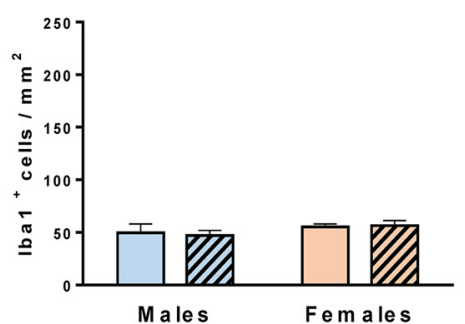

F 6

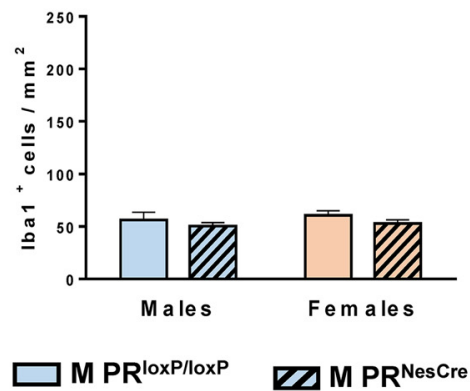

Aging

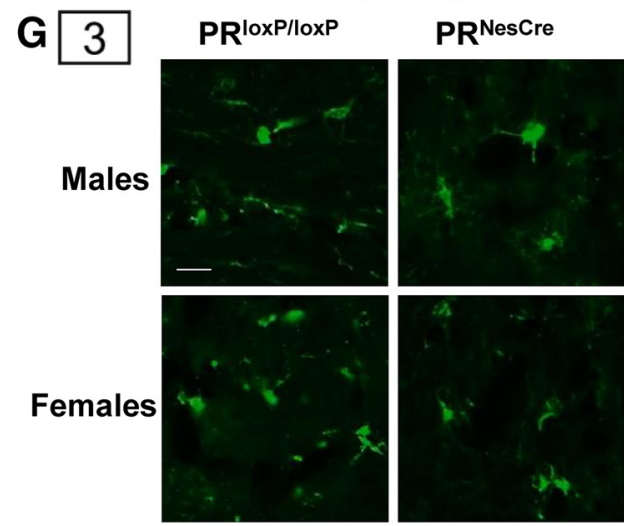

H 3
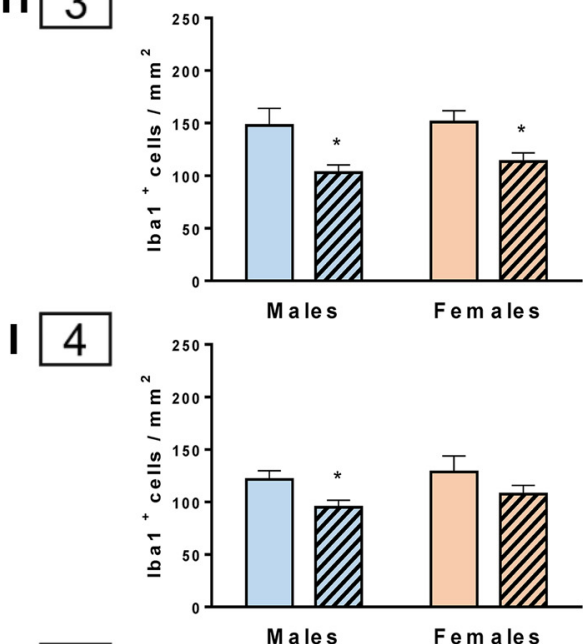

J 5

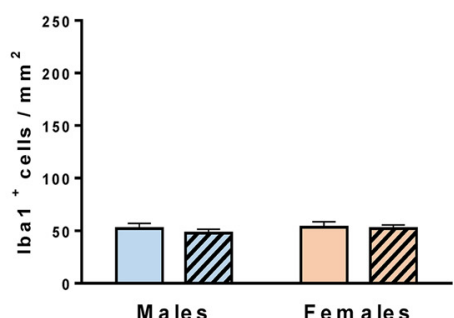

$\mathbf{K} 6$

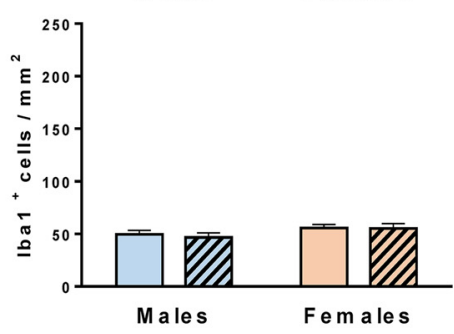

$\square$ F PR loxPlloxP $\square$ F PR NesCre

Figure 9. The density of activated Iba ${ }^{+}{ }^{+}$microglial cells at $6 \mathrm{~h}$ after MCAO was decreased in the peri-infarct in young and aging mice after deletion of PR in the brain. $A$, Localization of the four regions where microglial cells were counted at the level of the cerebral cortex and striatum. The regions are drawn on a coronal brain section taken from the atlas of Franklin and Paxinos (2008) at the level of bregma +0.14 . The infarct area is presented schematically in gray. $\boldsymbol{B}, \mathbf{G}$, Representative immunofluorescence staining of Iba ${ }^{+}$microglial cells (Figure legend continues.) 
density of Iba ${ }^{+}$cells was low with no effect of PR deletion (Fig. $9 J, K)$.

\section{Discussion}

In this study, we demonstrate the importance of endogenous progesterone, its metabolites, and neural PRs, in cerebroprotection in young and aging mice of both sexes during the early acute phase after stroke. We chose females in diestrus, a stage lasting $>2 \mathrm{~d}$ of the $4 \mathrm{~d}$ reproductive cycle (Byers et al., 2012) because it was considered to be advisable to avoid short peak levels of ovarian progesterone and estradiol (Smith et al., 1975; Nilsson et al., 2015) in order to uncover a role of endogenous brain progesterone in female cerebroprotection. Only limited information is available concerning the influence of the estrus cycle on responses to cerebral ischemia, but one study reported that hypertensive female rats develop smaller cerebral infarcts during the short proestrus stage (Carswell et al., 2000).

The unexpected results of brain steroid profiling by GCMS/MS lent further support to the notion that progesterone and its metabolites are important brain steroids in males. Whereas levels of neuroactive $5 \alpha$-reduced metabolites of progesterone were particularly elevated in the male brain, females instead produced larger amounts of $20 \alpha$-DHP. This metabolite of progesterone has been reported to have little affinity for PR and no progestogenic activity (Nadeem et al., 2016). Instead, because the formation of the $20 \alpha$-hydroxy-pregnanes is reversible, they may regulate the availability of biologically active 20-keto-pregnanes (Pelletier, 2010). Even more striking was the rapid and marked increase in brain levels of the PR ligands progesterone and $5 \alpha$ DHP after MCAO in males but not in females.

Because of its elevated endogenous brain levels of progesterone and $5 \alpha$-DHP, one may have predicted the male brain to be more resistant to ischemic damage than the female brain. However, this was not the case under the present experimental conditions: infarct volume and neurological deficit scores did not differ between male and female PR ${ }^{\text {loxPlloxP }}$ mice at $6 \mathrm{~h}$ after MCAO. Moreover, in both sexes, infarct volumes and neurological deficits were increased and neuronal densities decreased in PR ${ }^{\text {NesCre }}$ mice, demonstrating an important role of PR signaling in the resistance of brain tissue to ischemic damage for both sexes. Somehow, the low brain levels of progesterone and $5 \alpha$-DHP in females were sufficient for efficient cerebroprotection. However, males may rely more than females on cerebroprotection by en-

\section{$\leftarrow$}

(Figure legend continued.) in region 3 (peri-infarct in the cerebral cortex) of young and aging $P R^{\text {loxP/loxP }}$ and PR ${ }^{\text {NesCre }}$ mice of both sexes. Scale bar, $100 \mu \mathrm{m} . \boldsymbol{B}-\boldsymbol{F}$, Microglial density in young mice. $\boldsymbol{C}$, In region 3 (peri-infarct in the cerebral cortex), the density of $\mathrm{Iba} 1^{+}$cells was lower in $P R{ }^{\text {NesCre }}$ mice compared with PR ${ }^{\text {loxP/loxP }}$ mice (effect of genotype: $F_{(1,18)}=22.8, p=0.0002$ ). In $P R^{\text {loxP/loxP }}$ mice, the density of microglial cells was slightly higher in females (effect of sex: $\left.F_{(1,18)}=7.68, p=0.013\right)$. $D$, In region 4 (peri-infarct in the striatum), as in cerebral cortex, the density of Iba1 ${ }^{+}$cells was lower in PR ${ }^{\text {NesCre }}$ mice compared with PR ${ }^{\text {loxP/loxP }}$ mice (effect of genotype: $\left.F_{(1,18)}=22.8, p=0.0002\right) . \boldsymbol{E}, \boldsymbol{F}$, In contrast, the density of microglial cells was low and not affected by the inactivation of PR or the sex of the mice in cerebral cortex $(\boldsymbol{E})$ and striatum $(\boldsymbol{F})$ of the contralateral nonischemic hemisphere (in regions 5 and 6). $\boldsymbol{G}-\boldsymbol{K}$, Microglial density in aging mice. $\boldsymbol{H}, \boldsymbol{I}$, in the peri-infarct in cerebral cortex $(\boldsymbol{H})$ and striatum $(\boldsymbol{I})$, the density of Iba $1^{+}$microglial cells was lower in PR ${ }^{\text {NesCre }}$ mice compared with PR ${ }^{\text {loxP/loxP }}$ mice (effect of genotype: cerebral cortex: $F_{(1,20)}=15.6, p=0.0008$; striatum: $F_{(1,20)}=6.02, p=0.024$ ). $\boldsymbol{J}, \boldsymbol{K}$, As for the young mice, the density of microglial cells was low and not affected by the inactivation of PR in cerebral cortex $(\boldsymbol{J})$ and striatum $(\boldsymbol{K})$ of the contralateral nonischemic hemisphere (in regions 5 and 6 ) of both sexes. Results are presented as means \pm SEM ( $n=5-7$ per group) and were analyzed by Newman-Keuls multiple-comparisons tests after two-way ANOVA (sex $\times$ genotype). ${ }^{* * *} p<0.001,{ }^{* *} p<0.01,{ }^{*} p<0.05$ compared with $\mathrm{PR}$ loxP/loxP mice or as indicated. dogenous progesterone and $5 \alpha$-DHP, as suggested by the larger infarct volumes in $\mathrm{PR}^{\mathrm{Nes} C r e}$ males compared with $\mathrm{PR}^{\mathrm{Nes} C r e}$ females. These observations point to additional protective mechanisms against ischemic injury in the female brain.

An auxiliary cerebroprotective agent may be estradiol despite the fact that similar low brain levels of the hormone were measured in both sexes and they were not increased in response to $\mathrm{MCAO}$. Females may indeed be more sensitive to the cerebroprotective effects of estradiol than males because estrogen receptor $\alpha$ $(\mathrm{ER} \alpha)$ is upregulated rapidly in the ischemic brain of females but not males (Dubal et al., 2006; Westberry et al., 2008). Estrogens may potentiate the cerebroprotective effects of progesterone in females by upregulating PR expression (Waters et al., 2008).

Steroid profiling revealed other potential cerebroprotective mechanisms in females. Therefore, whereas progesterone is mainly converted to $5 \alpha$-reduced metabolites in males, females produce higher amounts of $\mathrm{GABA}_{\mathrm{A}}$ receptor active $5 \beta$-reduced metabolites of progesterone and DOC, respectively, $3 \alpha, 5 \beta$-THP, and $3 \alpha, 5 \beta$-THDOC (Gunn et al., 2015). The positive modulation of $\mathrm{GABA}_{\mathrm{A}}$ receptors by $3 \alpha$-reduced metabolites of progesterone and DOC and the resulting decrease in neuronal excitability is indeed a well recognized mechanism involved in neuroprotective responses (Sayeed et al., 2006; Brinton, 2013; Melcangi and Panzica, 2014).

Another sex difference deserving attention was the exposure of the male brain to higher amounts of injury-induced corticosterone compared with females. Endogenous corticosterone and stress have indeed been shown to exacerbate brain injury resulting from cerebral ischemia and the suppression of glucocorticoid production or actions has been proposed as a therapeutic option for stroke patients (Smith-Swintosky et al., 1996). Progesterone has been shown recently to counter the deleterious effects of stress after brain ischemia (Espinosa-Garcia et al., 2017). In males, higher levels of progesterone and $5 \alpha$-DHP may protect the brain against the ischemia-induced rise in corticosterone, whereas lower levels of glucocorticoids may improve the resistance of the female brain to ischemic damage.

Previous studies have shown that CNS levels of progesterone are increased in response to traumatic brain and spinal cord injury and MCAO (Labombarda et al., 2006; Meffre et al., 2007; Liu et al., 2012; Lopez-Rodriguez et al., 2015, 2016). Because treatment with progesterone exerts protective effects in these different injury models, it has been presumed that increased production of progesterone may be part of protective responses of neural cells to injury (De Nicola et al., 2009). Here, we provide evidence for this concept by showing that deletion of PRs in the brain results in increased ischemic damage and aggravation of neurological deficits after MCAO in the absence of treatment with exogenous progesterone.

We have shown previously that the resistance of the brain to ischemic damage is decreased in total PR knock-out mice (Liu et al., 2012). However, this study did not allow us to distinguish between central and peripheral actions of progesterone. The present results demonstrate a key role of neural PR in the cerebroprotective effects of the hormone. This finding has two major implications. First, synthetic progestins, which have been designed to target PRs selectively for contraceptive purposes or for the treatment of endocrine disorders, may be used as cerebroprotective agents (Sitruk-Ware and El-Etr, 2013; Schumacher et al., 2014). However, synthetic progestins cannot mimic the complex and regulated metabolism of natural progesterone in the brain (Kumar et al., 2017). Second, a route of progesterone administration with direct access to the brain such as intranasal delivery 
may be particularly advantageous for acute stroke therapy (Fréchou et al., 2015).

In men and women, age is the most important risk factor for stroke and a prognostic marker for poor outcomes (Wong et al., 2013). Concordantly, studies involving aging animals report worse stroke outcomes (Liu et al., 2009). The present study confirms that infarct volumes are larger in aging than in young mice. Moreover, neurological deficits were more severe in aging PR ${ }^{\text {NesCre }}$ mice. Treatment with progesterone continues to reduce infarct volumes in aging rodents of both sexes (Wang et al., 2010; Gibson et al., 2011; Wali et al., 2016). Here, we show that endogenous PR-dependent cerebroprotective mechanisms remain operational in aging males and females: infarct volumes and neurological deficits were increased and the density of neurons decreased in $\mathrm{PR}^{\mathrm{Nes} C r e}$ mice compared with $P \mathrm{R}^{\text {loxP/loxP }}$ mice. The preservation of PR-dependent cerebroprotective mechanisms at the early acute phase after stroke could explain why the $6 \mathrm{~h}$ time window for treatment by progesterone is preserved in aging males and females (Yousuf et al., 2014).

In the $\mathrm{PR}{ }^{\mathrm{Nes} C r e}$ mice, $\mathrm{PR}$ expression was ablated in neurons, astrocytes, and oligodendrocytes, but not in microglial cells. The latter do not express PR even after lipopolysaccharide challenge (Sierra et al., 2008). Cell-specific inactivation of PR will allow us identify the neural cells on which progesterone and $5 \alpha$-DHP act.

Using GC-MS/MS technology for steroid profiling and conditional CNS-specific PR knock-out mice, the present study demonstrates an important role of endogenous progesterone and its metabolites in the resistance of brain tissue to ischemic damage. Importantly, endogenous PR-dependent cerebroprotective mechanisms are operational in young and aging males and females. Remarkably, summed brain levels of PR-active pregnanes are much higher in males than in females and they are specifically upregulated in males after MCAO. Therefore, progesterone and its neuroactive metabolites may play a particularly important role in the male brain.

\section{References}

Baulieu EE (1997) Neurosteroids: of the nervous system, by the nervous system, for the nervous system. Recent Prog Horm Res 52:1-32. Medline

Belelli D, Lambert JJ, Peters JA, Gee KW, Lan NC (1996) Modulation of human recombinant GABAA receptors by pregnanediols. Neuropharmacology 35:1223-1231. CrossRef Medline

Brinton RD (2013) Neurosteroids as regenerative agents in the brain: therapeutic implications. Nat Rev Endocrinol 9:241-250. CrossRef Medline

Brown TJ, Clark AS, MacLusky NJ (1987) Regional sex differences in progestin receptor induction in the rat hypothalamus: effects of various doses of estradiol benzoate. J Neurosci 7:2529-2536. Medline

Byers SL, Wiles MV, Dunn SL, Taft RA (2012) Mouse estrous cycle identification tool and images. PLoS One 7:e35538. CrossRef Medline

Campbell BCV, Donnan GA, Lees KR, Hacke W, Khatri P, Hill MD, Goyal M, Mitchell PJ, Saver JL, Diener HC, Davis SM (2015) Endovascular stent thrombectomy: the new standard of care for large vessel ischaemic stroke. Lancet Neurol 14:846-854. CrossRef Medline

Carmichael ST (2010) Targets for neural repair therapies after stroke. Stroke 41:S124-S126. CrossRef Medline

Carswell HV, Dominiczak F, Macrae IM (2000) Estrogen status affects sensitivity to focal cerebral ischemia in stroke-prone spontaneously hypertensive rats. Am J Physiol Hear Circ Physiol 278:H290-H294. Medline

Celotti F, Melcangi RC, Martini L (1992) The 5 alpha-reductase in the brain: molecular aspects and relation to brain function. Front Neuroendocrinol 13:163-215. Medline

Chen M, Penning TM (2014) 5beta-Reduced steroids and human Delta(4)3-ketosteroid 5beta-reductase (AKR1D1). Steroids 83:17-26. CrossRef Medline

De Nicola AF, Labombarda F, Gonzalez Deniselle MC, Gonzalez SL, Garay L, Meyer M, Gargiulo G, Guennoun R, Schumacher M (2009) Progester- one neuroprotection in traumatic CNS injury and motoneuron degeneration. Front Neuroendocrinol 30:173-187. CrossRef Medline

Donnan GA, Davis SM, Parsons MW, Ma H, Dewey HM, Howells DW (2011) How to make better use of thrombolytic therapy in acute ischemic stroke. Nat Rev Neurol 7:400-409. CrossRef Medline

Dubal DB, Rau SW, Shughrue PJ, Zhu H, Yu J, Cashion AB, Suzuki S, Gerhold LM, Bottner MB, Dubal SB, Merchanthaler I, Kindy MS, Wise PM (2006) Differential modulation of estrogen receptors (ERs) in ischemic brain injury: A role for $\mathrm{ER} \alpha$ in estradiol-mediated protection against delayed cell death. Endocrinology 147:3076-3084. CrossRef Medline

Espinosa-Garcia C, Sayeed I, Yousuf S, Atif F, Sergeeva EG, Neigh GN, Stein DG (2017) Stress primes microglial polarization after global ischemia: therapeutic potential of progesterone. Brain Behav Immun pii: S08891591(17)30201-5. CrossRef Medline

Fisher M (2011) New approaches to neuroprotective drug development. Stroke 42:S24-S27. CrossRef Medline

Franklin K, Paxinos G (2008) The mouse brain in stereotaxic coordinates, 3rd ed. Amsterdam: Elsevier.

Fréchou M, Zhang S, Liere P, Delespierre B, Soyed N, Pianos A, Schumacher M, Mattern C, Guennoun R (2015) Intranasal delivery of progesterone after transient ischemic stroke decreases mortality and provides neuroprotection. Neuropharmacology 97:394-403. CrossRef Medline

Gibson CL, Murphy SP (2004) Progesterone enhances functional recovery after middle cerebral artery occlusion in male mice. J Cereb Blood Flow Metab 24:805-813. CrossRef Medline

Gibson CL, Coomber B, Murphy SP (2011) Progesterone is neuroprotective following cerebral ischaemia in reproductively ageing female mice. Brain 134:2125-2133. CrossRef Medline

Golanov EV, Reis DJ (1995) Contribution of cerebral edema to the neuronal salvage elicited by stimulation of cerebellar fastigial nucleus after occlusion of the middle cerebral artery in rat. J Cereb Blood Flow Metab 15: 172-174. CrossRef Medline

Grimm SL, Hartig SM, Edwards DP (2016) Progesterone receptor signaling mechanisms. J Mol Biol 428:3831-3849. CrossRef Medline

Gunn BG, Cunningham L, Mitchell SG, Swinny JD, Lambert JJ, Belelli D (2015) GABA receptor-acting neurosteroids: A role in the development and regulation of the stress response. Front Neuroendocrinol 36:28-48. CrossRef Medline

Hill KK, Roemer SC, Churchill ME, Edwards DP (2012) Structural and functional analysis of domains of the progesterone receptor. Mol Cell Endocrinol 348:418-429. CrossRef Medline

Hillisch A, von Langen J, Menzenbach B, Droescher P, Kaufmann G, Schneider B, Elger W (2003) The significance of the 20-carbonyl group of progesterone in steroid receptor binding: A molecular dynamics and structure-based ligand design study. Steroids 68:869-878. CrossRef Medline

Hosie AM, Wilkins ME, da Silva HM, Smart TG (2006) Endogenous neurosteroids regulate GABAA receptors through two discrete transmembrane sites. Nature 444:486-489. CrossRef Medline

Iadecola C, Anrather J (2011) Stroke research at a crossroad: asking the brain for directions. Nat Neurosci 14:1363-1368. CrossRef Medline

Kumar N, Fagart J, Liere P, Mitchell SJ, Knibb AR, Petit-Topin I, Rame M, El-Etr M, Schumacher M, Lambert JJ, Rafestin-Oblin ME, Sitruk-Ware R (2017) Nestorone ${ }^{\circledR}$ (NES) a novel progestin for non-oral contraception: structure-activity relationships and brain metabolism studies. Endocrinology 158:170-182. CrossRef Medline

Labombarda F, Pianos A, Liere P, Eychenne B, Gonzalez S, Cambourg A, De Nicola AF, Schumacher M, Guennoun R (2006) Injury elicited increase in spinal cord neurosteroid content analyzed by gas chromatography mass spectrometry. Endocrinology 147:1847-1859. CrossRef Medline

Lambert JJ, Cooper MA, Simmons RDJ, Weir CJ, Belelli D (2009) Neurosteroids: endogenous allosteric modulators of GABAA receptors. Psychoneuroendocrinology 34:48-58.

Lange CA, Gioeli D, Hammes SR, Marker PC (2007) Integration of rapid signaling events with steroid hormone receptor action in breast and prostate cancer. Annu Rev Physiol 69:171-199. CrossRef Medline

Liere P, Pianos A, Eychenne B, Cambourg A, Liu S, Griffiths W, Schumacher M, Sjövall J, Baulieu EE (2004) Novel lipoidal derivatives of pregnenolone and dehydroepiandrosterone and absence of their sulfated counterparts in rodent brain. J Lipid Res 45:2287-2302. CrossRef Medline

Liu A, Margaill I, Zhang S, Labombarda F, Coqueran B, Delespierre B, Liere P, Marchand-Leroux C, O’Malley BW, Lydon JP, De Nicola AF, SitrukWare R, Mattern C, Plotkine M, Schumacher M, Guennoun R (2012) 
Progesterone receptors: a key for neuroprotection in experimental stroke. Endocrinology 153:3747-3757. CrossRef Medline

Liu F, Yuan R, Benashski SE, McCullough LD (2009) Changes in experimental stroke outcome across the life span. J Cereb Blood Flow Metab 29:792-802. CrossRef Medline

Livak KJ, Schmittgen TD (2001) Analysis of relative gene expression data using real-time quantitative PCR and the 2- $\Delta \Delta$ CT method. Methods 25: 402-408. CrossRef Medline

Lopez-Rodriguez AB, Acaz-Fonseca E, Giatti S, Caruso D, Viveros MP, Melcangi RC, Garcia-Segura LM (2015) Correlation of brain levels of progesterone and dehydroepiandrosterone with neurological recovery after traumatic brain injury in female mice. Psychoneuroendocrinology 56:111. CrossRef Medline

Lopez-Rodriguez AB, Acaz-Fonseca E, Spezzano R, Giatti S, Caruso D, Viveros MP, Melcangi RC, Garcia-Segura LM (2016) Profiling neuroactive steroid levels after traumatic brain injury in male mice. Endocrinology 157:3983-3993. CrossRef Medline

Lydon JP, DeMayo FJ, Funk CR, Mani SK, Hughes AR, Montgomery CA Jr, Shyamala G, Conneely OM, O’Malley BW (1995) Mice lacking progesterone receptor exhibit pleiotropic reproductive abnormalities. Genes Dev 9:2266-2278. CrossRef Medline

Meffre D, Pianos A, Liere P, Eychenne B, Cambourg A, Schumacher M, Stein DG, Guennoun R (2007) Steroid profiling in brain and plasma of male and pseudopregnant female rats after traumatic brain injury: Analysis by gas chromatography/mass spectrometry. Endocrinology 148:2505-2517. CrossRef Medline

Melcangi RC, Panzica GC (2014) Allopregnanolone: state of the art. Prog Neurobiol 113:1-5. CrossRef Medline

Mergenthaler P, Dirnagl U (2011) Protective conditioning of the brain: expressway or roadblock? J Physiol 589:4147-4155. CrossRef Medline

Murr SM, Stabenfeldt GH, Bradford GE, Geschwind II (1974) Plasma testosterone during pregnancy in the mouse. Endocrinology 94:1209-1211. CrossRef Medline

Nadeem L, Shynlova O, Matysiak-Zablocki E, Mesiano S, Dong X, Lye S (2016) Molecular evidence of functional progesterone withdrawal in human myometrium. Nat Commun 7:11565. CrossRef Medline

Nilsson ME, Vandenput L, Tivesten Å, Norlén AK, Lagerquist MK, Windahl $\mathrm{SH}$, Börjesson AE, Farman HH, Poutanen M, Benrick A, Maliqueo M, Stener-Victorin E, Ryberg H, Ohlsson C (2015) Measurement of a comprehensive sex steroid profile in rodent serum by high-sensitive gas chromatography-tandem mass spectrometry. Endocrinology 156:24922502. CrossRef Medline

Pelletier G (2010) Steroidogenic enzymes in the brain: morphological aspects, Ed 1.New York: Elsevier.

Peinnequin A, Mouret C, Birot O, Alonso A, Mathieu J, Clarencon D, Agay D, Chancerelle Y, Multon E (2004) Rat pro-inflammatory cytokine and cytokine related mRNA quantification by real-time polymerase chain reaction using SYBR green. BMC Immunol 5:3. Medline

Poletti A, Coscarella A, Negri-Cesi P, Colciago A, Celotti F, Martini L (1998) 5 alpha-reductase isozymes in the central nervous system. Steroids 63: 246-251. CrossRef Medline

Raskin K, de Gendt K, Duittoz A, Liere P, Verhoeven G, Tronche F, MhaoutyKodja S (2009) Conditional inactivation of androgen receptor gene in the nervous system: effects on male behavioral and neuroendocrine responses. J Neurosci 29:4461-4470. CrossRef Medline

Rupprecht R, Reul JM, Trapp T, van Steensel B, Wetzel C, Damm K, Zieglgänsberger W, Holsboer F (1993) Progesterone receptor-mediated effects of neuroactive steroids. Neuron 11:523-530. CrossRef Medline

Sarkar J, Wakefield S, MacKenzie G, Moss SJ, Maguire J (2011) Neurosteroidogenesis is required for the physiological response to stress: role of neurosteroid-sensitive GABAA receptors. J Neurosci 31:18198-18210. CrossRef Medline

Saver JL (2006) Time is brain-quantified. Stroke 37:263-266. CrossRef Medline

Sayeed I, Stein DG (2009) Progesterone as a neuroprotective factor in traumatic and ischemic brain injury. New York: Elsevier.

Sayeed I, Guo Q, Hoffman SW, Stein DG (2006) Allopregnanolone, a pro- gesterone metabolite, is more effective than progesterone in reducing cortical infarct volume after transient middle cerebral artery occlusion. Ann Emerg Med 47:381-389. CrossRef Medline

Schumacher M, Mattern C, Ghoumari A, Oudinet JP, Liere P, Labombarda F, Sitruk-Ware R, De Nicola AF, Guennoun R (2014) Revisiting the roles of progesterone and allopregnanolone in the nervous system: resurgence of the progesterone receptors. Prog Neurobiol 113:6-39. CrossRef Medline

Sierra A, Gottfried-Blackmore A, Milner TA, McEwen BS, Bulloch K (2008) Steroid hormone receptor expression and function in microglia. Glia 56: 659-674. CrossRef Medline

Sitruk-Ware R, El-Etr M (2013) Progesterone and related progestins: potential new health benefits. Climacteric 16:69-78. CrossRef Medline

Smith MS, Freeman ME, Neill JD (1975) The control of progesterone secretion during the estrous cycle and early pseudopregnancy in the rat: prolactin, gonadotropin and steroid levels associated with rescue of the corpus luteum of pseudopregnancy. Endocrinology 96:219-226. CrossRef Medline

Smith-Swintosky VL, Pettigrew LC, Sapolsky RM, Phares C, Craddock SD, Brooke SM, Mattson MP (1996) Metyrapone, an inhibitor of glucocorticoid production, reduces brain injury induced by focal and global ischemia and seizures. J Cereb Blood Flow Metab 16:585-598. CrossRef Medline

Traish AM, Wotiz HH (1990) Monoclonal and polyclonal antibodies to human progesterone receptor peptide-(533-547) recognize a specific site in unactivated $(8 \mathrm{~S})$ and activated $(4 \mathrm{~S})$ progesterone receptor and distinguish between intact and proteolyzed receptors. Endocrinology 127:1167-1175. CrossRef Medline

Tronche F, Kellendonk C, Kretz O, Gass P, Anlag K, Orban PC, Bock R, Klein R, Schütz G (1999) Disruption of the glucocorticoid receptor gene in the nervous system results in reduced anxiety. Nat Genet 23:99-103. CrossRef Medline

Türeyen K, Vemuganti R, Sailor KA, Dempsey RJ (2004) Infarct volume quantification in mouse focal cerebral ischemia: a comparison of triphenyltetrazolium chloride and cresyl violet staining techniques. J Neurosci Methods 139:203-207. CrossRef Medline

Vivien D, Gauberti M, Montagne A, Defer G, Touzé E (2011) Impact of tissue plasminogen activator on the neurovascular unit: from clinical data to experimental evidence. J Cereb Blood Flow Metab 31:2119-2134. CrossRef Medline

Wali B, Ishrat T, Won S, Stein DG, Sayeed I (2014) Progesterone in experimental permanent stroke: a dose-response and therapeutic time-window study. Brain 137:486-502. CrossRef Medline

Wali B, Ishrat T, Stein DG, Sayeed I (2016) Progesterone improves longterm functional and histological outcomes after permanent stroke in older rats. Behav Brain Res 305:46-56. CrossRef Medline

Wang J, Jiang C, Liu C, Li X, Chen N, Hao Y (2010) Neuroprotective effects of progesterone following stroke in aged rats. Behav Brain Res 209:119 122. CrossRef Medline

Waters EM, Torres-Reveron A, McEwen BS, Milner TA (2008) Ultrastructural localization of extranuclear progestin receptors in the rat hippocampal formation. J Comp Neurol 511:34-46. CrossRef Medline

Westberry JM, Prewitt AK, Wilson ME (2008) Epigenetic regulation of the estrogen receptor alpha promoter in the cerebral cortex following ischemia in male and female rats. Neuroscience 152:982-989. CrossRef Medline

Williams KC, Renthal NE, Condon JC, Gerard RD, Mendelson CR (2012) MicroRNA-200a serves a key role in the decline of progesterone receptor function leading to term and preterm labor. Proc Natl Acad Sci U S A 109:7529-7534. CrossRef Medline

Wong R, Bath PM, Kendall D, Gibson CL (2013) Progesterone and cerebral ischaemia: the relevance of ageing. J Neuroendocrinol 25:1088-1094. CrossRef Medline

Yousuf S, Sayeed I, Atif F, Tang H, Wang J, Stein DG (2014) Delayed progesterone treatment reduces brain infarction and improves functional outcomes after ischemic stroke: a time-window study in middle-aged rats. J Cereb Blood Flow Metab 34:297-306. CrossRef Medline 